\title{
Design science in
} operations management: extracting knowledge from maturing designs

Mikael Öhman

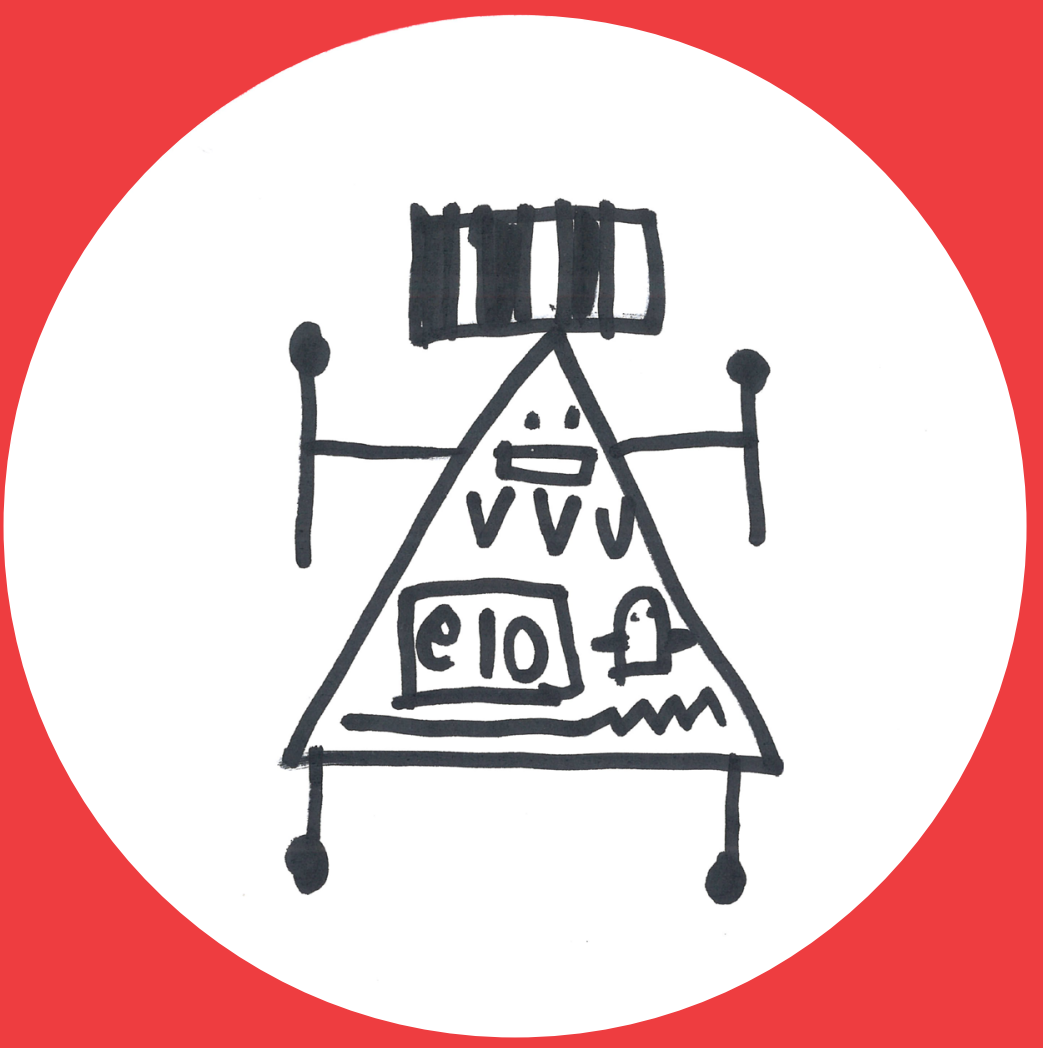




\title{
Design science in operations management: extracting knowledge from maturing designs
}

\author{
Mikael Öhman
}

A doctoral dissertation completed for the degree of Doctor of Science (Technology) to be defended, with the permission of the Aalto University School of Science, at a public examination held at the lecture hall AS2 of the school on 23 May 2019 at noon. 


\section{Supervising professor}

Prof. Jan Holmström, Aalto Unitversity School of Science, Finland

\section{Preliminary examiners}

Prof. dr. Henk Akkermans, Tilburg University, The Netherlands

Prof. Rikard Lindgren, University of Gothenburg, Sweden

\section{Opponents}

Prof. em. Joan van Aken, Design Science Research Institute, The Netherlands

Prof. dr. Henk Akkermans, Tilburg University, The Netherlands

\section{Aalto University publication series}

\section{DOCTORAL DISSERTATIONS 59/2019}

(C) 2019 Mikael Öhman

ISBN 978-952-60-8474-9 (printed)

ISBN 978-952-60-8487-9 (pdf)

ISSN 1799-4934 (printed)

ISSN 1799-4942 (pdf)

http://urn.fi/URN:ISBN:978-952-60-8487-9

Images: 'The machine that no one has ever seen (before)' - cover

image by Robin Öhman

Unigrafia Oy

Helsinki 2019

Finland 
Author

Mikael Öhman

Name of the doctoral dissertation

Design science in operations management: extracting knowledge from maturing designs

\begin{tabular}{|c|c|c|}
\hline \multicolumn{3}{|c|}{ Publisher School of Science } \\
\hline \multicolumn{3}{|c|}{ Unit Department of Industrial Engineering and Management } \\
\hline \multicolumn{3}{|c|}{ Series Aalto University publication series DOCTORAL DISSERTATIONS 59/2019 } \\
\hline \multicolumn{3}{|c|}{ Field of research Operations and Service Management } \\
\hline \multicolumn{3}{|c|}{ Manuscript submitted 11 November 2018} \\
\hline \multicolumn{3}{|c|}{ Permission for public defence granted (date) 16 January 2019} \\
\hline$\square$ Monograph & $\bigotimes$ Article dissertation & $\square$ Essay dissertation \\
\hline
\end{tabular}

Abstract

Most scholars would agree that the mission of science is to answer questions that matter the most to society. Yet, practical relevance of Operations Management (OM) research has been a persistent concern of academics in the field. This has produced an ongoing discussion of how the gap between theory and practice could be bridged, with methodological ramifications of proposed solutions causing tensions in the field. Design science (DS) has emerged as a promising solution to the relevance problem, and is currently establishing itself in the field of OM.

While DS has recently been acknowledged as a legitimate research strategy in OM, its novelty predicts an upcoming methodological debate. The aim of this dissertation is to propose a foundation for this debate, which would guide the methodological development of DS in OM in a direction that effectively bridges the relevance gap. The main thesis being that the methodological debate should be based on and built around design maturity.

This dissertation is a methodological compilation of four research papers, each of which reports an OM DS study, with designs of varying maturity. The studies use an array of methods ranging from simulation and quantitative analysis of operational data, to semi-structured interviews and participant observation. Based on the studies I propose a conceptualization of design maturity, and discuss knowledge creation and extraction at different stages of design maturity.

In addition to the main thesis that the forthcoming methodological debate in OM should be built around design maturity, I posit that for DS in OM: (1) differentiating and explicating the relationship (interfaces) between design and context is crucial. (2) Methods should be evaluated based on their ability to produce understanding of the context. (3) Designer self-reflection should be an integral part of research communication.

While the work compiled in this dissertation has had a real and practical impact on the studied contexts, general practical implications are indirect. These implications rest on the expectation that the results contribute to the emergence of a methodologically coherent stream of DS research in OM. Over time, this is expected to bridge the gap between practice and theory, securing the relevance and increasing the impact of future OM research.

Keywords design science, methodology, design maturity, operations management, practicetheory gap

\begin{tabular}{lc}
\hline ISBN (printed) $978-952-60-8474-9$ & ISBN (pdf) $978-952-60-8487-9$ \\
\hline ISSN (printed) $1799-4934$ & ISSN (pdf) $1799-4942$ \\
\hline Location of publisher Helsinki & Location of printing Helsinki $\quad$ Year 2019 \\
\hline Pages 200 & urn http://urn.fi/URN:ISBN:978-952-60-8487-9 \\
\hline
\end{tabular}



Tekijä

Mikael Öhman

Väitöskirjan nimi

Suunnittelutiede operaatioiden johtamistutkimuksessa: artefaktien maturiteetti tieteen tekemisen perustana

\begin{tabular}{|c|c|}
\hline \multicolumn{2}{|l|}{ Julkaisija Perustieteiden korkeakoulu } \\
\hline Yksikkö Tuotantotalouden laitos & \\
\hline \multicolumn{2}{|c|}{ Sarja Aalto University publication series DOCTORAL DISSERTATIONS 59/2019 } \\
\hline \multicolumn{2}{|l|}{ Tutkimusala Operaatioiden ja palveluiden johtaminen } \\
\hline Käsikirjoituksen pvm 11.11.2018 & Väitöspäivä 23.05.2019 \\
\hline Väittelyluvan myöntämispäivä 16.01 .2019 & Kieli Englanti \\
\hline$\triangle$ Artikkeliväitöskirja & $\square$ Esseeväitöskirja \\
\hline
\end{tabular}

\section{Tiivistelmä}

Useimmat tutkijat olisivat samaa mieltä siitä, että tieteen tehtävänä on vastata yhteiskunnan kannalta relevantteihin kysymyksiin. Operaatioiden johtamisen (eng. Operations management) tutkimusalalla, tutkimuksen relevanssi on kuitenkin ollut alan tutkijoiden huolenaiheena. Tätä kuvastaa alalla jatkuva keskustelu siitä, miten teorian ja käytännön välinen kuilu voitaisiin kuroa kiinni. Keskustelu nostaa kuitenkin pintaan alalla vallitsevien tieteenfilosofisten suuntausten ja perinteiden väliset jännitteet, joka hankaloittaa ratkaisun löytymistä. Hiljattain alalla asemaansa vakiinnuttanut suunnittelutiede (eng. Design Science) nähdään kuitenkin lupaavana ratkaisuna. Suunnittelutieteiden aseman vakiintuessa, metodologinen keskustelu voi siirtyä tutkimusstrategian legitimiteetin argumentoimisesta siihen, miten suunnittelutieteellistä tutkimusta tulisi operaatioiden johtamisen alalla tehdä. Tämän väitöskirjan puitteissa esitän viitekehyksen johon perustuen tuleva metodologinen keskustelu jäsentyisi nimenomaan teorian ja käytännön välisen kuilun silloittamiseen. Väitöskirjani keskeinen teesi on, että tuleva metodologinen keskustelu tulisi perustaa artefaktien (eng. designs) maturiteettiin.

Väitöskirja muodostaa metodologisen koosteen neljästä erillisestä alan tutkimuksesta, joissa olen käyttänyt suunnittelutieteellistä tutkimusstrategiaa. Tutkimuksissa käytetään laajaa menetelmäkirjoa, simuloinnista ja operatiivisten datan kvantitatiivisesta analysista, teemahaastatteluihin ja havainnointiin. Tutkimusten perusteella käsitteellistän artefaktien maturiteetin, ja keskustelen siitä miten eri maturiteetti-vaiheet voivat tuottaa uutta tietoa. Maturiteettiin perustuvan viitekehyksen lisäksi esitän kolme väittämää suunnittelutieteellisen tutkimuksen erityispiirteistä operaatioiden johtamisen tutkimusalalla: (1) Artefaktin ja kontekstin välisten rajapintojen ymmärtäminen on ratkaisevan tärkeää. (2) Tutkimusmenetelmiä tulisi arvioida sen perusteella mikä on niiden kyky tuottaa ymmärrystä kontekstista. (3) Suunnittelijan itse-reflektoinnin tulisi olla osa tutkimusviestintää.

Väitöskirjaan kuuluvilla yksittäisillä tutkimuksilla on ollut suora vaikutus käytäntöön.

Kokonaisuutena väitöskirjan vaikutus käytäntöön on kuitenkin välillinen, ja perustuu odotukseen että maturiteetti-viitekehys luo koherenssia ja johdonmukaisuutta tulevaan metodologiseen kehitystyöhön. Ajan mittaan väitöskirja olisi täten osa suunnittelutieteellistä teorian ja käytännön silloitustyötä, jolla varmistetaan operaatioiden johtamistutkimuksen tulevaisuuden relevanssi ja vaikuttavuus.

Avainsanat suunnittelutiede, metodologia, artefaktien maturiteetti, operaatioiden johtaminen, käytännön ja teorian välinen kuilu

\begin{tabular}{|c|c|c|}
\hline ISBN (painettu) 978-952-60 & ISBN (pc & $50-8487-9$ \\
\hline ISSN (painettu) 1799-4934 & ISSN (p) & \\
\hline Julkaisupaikka Helsinki & Painopaikka Helsinki & Vuosi 2019 \\
\hline
\end{tabular}





\section{Acknowledgements}

"A good dissertation is a done dissertation. A great dissertation is a published dissertation. A perfect dissertation is neither"

Unknown

As per the definition above, it appears as if I am now the author of a great dissertation. With my internal perfectionist laughing while I was writing the prior sentence, a retrospective look at the years invested in this project invites me to explore other meanings of the word great. Several alternative forms of greatness emerge. I consider this book a melting pot of countless great discussions with a great number of great people throughout the journey that comprises this dissertation. From this vantage point, this journey was indeed a great experience, and it has provided many great times in the process. I am left feeling grateful (pun intended).

I would like to thank my boss, mentor, instructor and supervisor, prof. Jan Holmström for being my friend throughout the process - you are by all standards an exceptional academic leader, and it has been a pleasure to work with you. Jan has always sought to push my intellectual boundaries, relentlessly focusing on alternatives and solutions where others might have pointed out problems and shortcomings. I have enjoyed all our discussions - ranging from the fundaments of design science, to the institutional problems of academia, to the challenges of parenting. I would also like to thank my co-authors prof. Kari Tanskanen, prof. Kai Virtanen and Markus Hiltunen for good and fruitful co-operation. A special thank you goes to my co-author prof. Max Finne. Max is an exceptional listener who has always genuinely tried to understand even my most incomprehensible ideas - often resulting in myself understanding that they are, indeed, incomprehensible.

I would like to thank my pre-examiners, prof.dr. Henk Akkermans and prof. Rikard Lindgren, for their well-founded criticism, constructive comments and encouraging feedback. Further, I would like to thank prof.dr. Akkermans again, together with prof.em. Joan van Aken for acting as my opponents.

There have been many colleagues throughout the years, all of whom have left a lasting impression on me, subtly contributing to my view of the world, making it more nuanced, ever clearer and so much sharper. You were my roommates: Siavash, Naser and Alireza. You were the Logistics Research Group: Riikka, 
Max, Mervi, Saara, Ville, Pekka, Anna, Jouni, Maija, Sonja, Matti, Annika and Jaakko. You were the knights of the SLR: Max, Olga, Juha and Juha. You were my thesis students: Xuemei, Mikko, Ilari and Chethana. You were my research assistants: Müge and Petri. You were my BB8 course mates: Jussi, Tania, Jussi, Noora, Vincent, Jinze, Katharina, Colm, Tuija, Pia, Abdollah and Synes. You were colleagues that labels aside, simply made my days: Esko, Ulriikka, Pekka, Risto, Karlos, Esa, Paul, Matti, Kary, Riitta, Suvi, Päivi, Meijan, Ville, Satu, An, Iiris, Heini, Shan, Outi, Jaakko, Kirsi, Tuomo and Emma. Thank you all.

When my children ask what I do at work, I say that I read and write a lot, and teach in between. Probably not very exciting to those who dream of riding dinosaurs. However, work has also led me to unexpected places and situations, such as crossing the border between South and North Korea, traveling at James Bond-speed through Tallinn just to miss the ferry back to Helsinki and discussing hockey with Russian businessmen in an Austrian sauna. In my research, I have also been in places that are off limits to most people - in the cargo-hold of an Airbus 330, inside an elevator shaft and underneath a Pendolino. For this, I have to thank the people who opened their operations for me and shared their data, thoughts, insights and wisdom: Ulla, Päivi, Olli, Riitta, Juha, Aki, Pasi, Mikko, Juha, Ville, Juha, Mikko and Juha. I would also like to thank all my financiers throughout the years: Tekes - mainly through the FutIS and S4Fleet programs orchestrated by FIMECC, later DIMECC, Tekniikan Edistämissäätiö, Yrjö ja Senja Koivusen säätiö and Heikki ja Hilma Honkasen säätiö.

During these years, work has only accounted for a minor part of my life, and the awesome people surrounding me outside of work have had an equally real and significant impact on my perception of life, society and the human condition. You are the lads: Lagge, Peik, Denna, Osku, Kalle, Anders, Ivu, Korven, Släggan, Chuda and Flood. The annual mökkikeikka, bi-annual netmeetings and the quarterly afterworks have always been something to look forward to when work has not. You are my TKK friends: Simon and Johan. You are the friends and family that I have gotten to know through my wife: Hecko, Janne, Hencka, Jonny, Vicke, Ylva, Jenny, Pekka, Jonas, Lotta, Anna, Sara, Eva and Jenny.

Finally, all truly great things rest on strong foundations. The strength and inspiration provided by my families is far beyond the words written here. My father Janne, who inspires me with his great ingenuity and an amazing drive to get things done. My mother Kristiina, who inspires me with her thoughtfulness and curiosity for the universe. My sister Maria, who inspires me with her determination and independence. My wife Janina, who inspires me with her goodness, patience and forgivingness. My son Robin, who inspires me with his compassion and courage. My son Felix, who inspires me with his wittiness and optimism. My daughter Ronja, who's smile lights up even the darkest of days. Thank you all. I love you.

Otaniemi, 9 April 2019

Mikael Alexander Öhman 


\section{Contents}

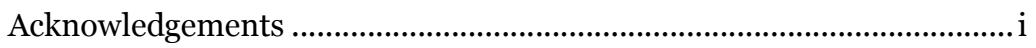

List of Abbreviations and Symbols.......................................................... V

List of Research Articles ....................................................................... vi

Author's Contribution ........................................................................... vii

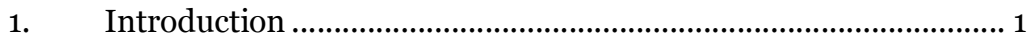

1.1 Research objective and questions .............................................. 3

$1.2 \quad$ Empirical context(s).............................................................

1.3 Scope and structure of the thesis ............................................. 4

2. Literature review.............................................................................. 7

2.1 Understanding the artificial through design ............................... 7

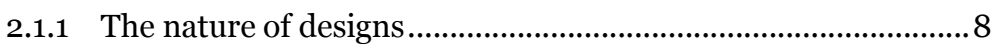

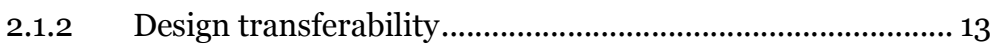

2.1.3 Exploration through design .................................................... 14

2.1.4 How designs mature ................................................................. 14

2.2 Creating knowledge through design ......................................... 16

2.2.1 Articulating design knowledge ............................................... 16

2.2.2 Design propositions ............................................................... 18

2.2.3 Knowledge creation in the design process............................20

2.3 Contemporary design science research in OM.........................23

3. $\quad$ Research design ............................................................................. 27

3.1 Case studies as context-bound inquiries .................................29

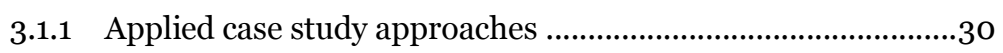

3.1.2 Applied approaches for studying the long-term ...................32

3.2 Collecting evidence on designs and context ..............................34

3.3 Analyzing evidence on designs and context .............................. 37

4. Findings ....................................................................................... 41

4.1 How designs mature ................................................................ 41

4.1.1 Pre-implementation..................................................................42

4.1.2 Implementation...................................................................44 
4.1.3 Re-implementation ............................................................ 45

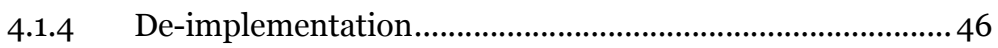

4.2 Extracting knowledge from maturing designs.........................46

4.2.1 Pre-implementation.......................................................... 47

4.2.2 Implementation .................................................................. 49

4.2.3 Re-implementation............................................................. 50

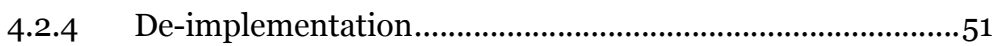

4.3 Maturity and knowledge creation in contemporary OM DS... 53

4.3.1 Design maturity in contemporary OM DS ............................. 53

4.3.2 Knowledge created in contemporary OM DS....................... 54

5. Discussion .....................................................................................57

5.1 Contribution to Design Science in OM.....................................58

5.1.1 Conceptualization of designs for knowledge production ......... 59

5.1.2 Methods for producing knowledge through designs ............60

5.1.3 The designer as a source of knowledge..................................61

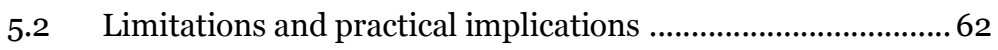

5.3 On the future of Design Science in OM ..................................... 63

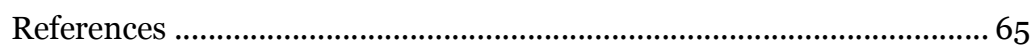

Appendices I-IV: Original research articles ......................................... 74 


\section{List of Abbreviations and Symbols}

$\begin{array}{ll}\text { APM } & \text { Adaptive Preventive Maintenance } \\ \text { CBM } & \text { Condition Based Maintenance } \\ \text { CIMO } & \text { Context Intervention Mechanism Outcome } \\ \text { DS } & \text { Design Science } \\ \text { DSR } & \text { Design Science Research } \\ \text { HRM } & \text { Human Resource Management } \\ \text { IBI } & \text { Installed Base Information } \\ \text { IS } & \text { Information Systems } \\ \text { ISDT } & \text { Information Systems Design Theory } \\ \text { JIT } & \text { Just-in-time } \\ \text { OM } & \text { Operations Management } \\ \text { RCM } & \text { Reliability Centered Maintenance } \\ \text { SPC } & \text { Statistical Process Control } \\ \text { VMI } & \text { Vendor Managed Inventory }\end{array}$




\section{List of Research Articles}

This doctoral dissertation consists of a summary and of the following articles, which are referred to in the text by their numerals

1. Öhman, M., Finne, M., \& Holmström, J. (2015). Measuring service outcomes for adaptive preventive maintenance. International Journal of Production Economics, 170, 457-467.

2. Öhman, M., Hiltunen, M., Virtanen, K., \& Holmström, J. (Working paper'1). Innovation in Lean Buffer Management: Seeking Theoretical Insights and Novel Solutions in Aircraft Line Maintenance.

3. Tanskanen, K., Holmström, J., \& Öhman, M. (2015). Generative mechanisms of the adoption of logistics innovation: The case of On-site Shops in construction supply chains. Journal of Business Logistics, 36(2), 139-159.

4. Öhman, M., \& Holmström, J. (Working paper ${ }^{2}$ ). A contingent design theory of Condition-Based Maintenance.

\footnotetext{
${ }^{1}$ Research article 2 is currently in review for the Journal of Operations Management.

${ }^{2}$ Research article 4 is currently being developed for resubmission to the Journal of Operations Management, based on the suggestions accompanied by a prior reject and resubmit-decision. 


\section{Author's Contribution}

Article 1: Measuring service outcomes for adaptive preventive maintenance

Based on his original idea, Öhman conducted data collection and -analysis, including conceptual development of the design. Öhman also had the main responsibility in writing the article and explicating theoretical contributions, with Finne and Holmström offering support.

Article 2: Innovation in Lean Buffer Management: Seeking Theoretical Insights and Novel Solutions in Aircraft Line Maintenance

Based on the original idea of Öhman, Hiltunen conducted the data collection and built the simulation model. Öhman developed and explicated the theoretical contributions, and wrote the article. Virtanen provided extensive support during the entire research process, whereas Holmström provided support mainly in the writing of the article.

Article 3: Generative mechanisms of the adoption of logistics innovation: The case of On-site Shops in construction supply chains

Based on the original idea of Tanskanen and Holmström, Öhman participated in research design, and had the main responsibility for data collection and analysis, including crafting of initial theoretical contributions. Tanskanen and Holmström had the main responsibility for honing theoretical contributions and writing the article, with Öhman supporting the process.

Article 4: A contingent design theory of Condition-Based Maintenance

The article is based on the original idea of Öhman, who also collected the data in the polar case studies. As for the multiple case studies, data collection was a joint effort between Öhman and thesis worker Xuemei Sun. Öhman analyzed the data, developed and explicated the theoretical contributions, and wrote the article. Holmström provided support mainly during writing of the article.

An external service provider transcribed the majority of the interviews conducted for each of the research articles. The author reviewed the interview transcripts, to ensure that they offered an accurate recount of the conducted interviews. In cases of interview-transcript incongruence, the author corrected the transcript, sometimes resorting to the original interview recording. 
Language editing services were used in all research articles. The author subsequently reviewed every change made by the professional editor, correcting possible misunderstandings. 


\section{Introduction}

"In the field of operations management (OM), however, it is not clear whether much if anything would change in practice if the entire group of academics suddenly disappeared."

(de Treville, Edelson, Kharkar, \& Avanzi, 2009, p. 15)

The role and mission of science is arguably to address complex questions that matter most to society (Adler \& Harzing, 2009). In the field of management, societal impact of research is often seen through managerial impact (Bartunek \& Rynes, 2010), and the extent to which research is expected to impact management (and society by extension) is typically discussed in terms of relevance. As a concept, relevance is far from unambiguous (Ketokivi, 2009), with differences in the philosophical underpinnings of research leading to two contrasting views on when research is relevant. Theory-oriented scientists, primarily engaged in deductive research, argue that science has an intrinsic value, which serves as a foundation for theoretical development - arguing that truly great discoveries (which ultimately benefit society) can only be achieved, if science is done for the sake of science. On the other hand, practice-oriented scientists, mainly engaged in inductive and abductive research, argue that societal benefit is driven by close collaboration with society - arguing that the value of research is determined by the extent to which it helps managers in solving the management problems they face. Diverging views aside, both camps share a persistent concern for the low impact, and by extension low practical relevance, of (operations) management research (cf. Beyer \& Trice, 1982; Hambrick, 1994; Kieser, Nicolai, \& Seidl, 2015; Romme, 2003; Schmenner \& Swink, 1998; Schmenner, Wassenhove, Ketokivi, Heyl, \& Lusch, 2009; van Aken, 2004).

Design science (DS) has been portrayed as a solution to the relevance problem (Holmström, Ketokivi, \& Hameri, 2009; Romme, 2003; van Aken, 2004), and has consequently gained traction in both management (eg. Jelinek, Romme, \& Boland, 2008) and operations management (OM) (cf. van Aken, Chandrasekaran, \& Halman, 2016). However, due to the relative novelty of the research approach, most of the methodological discussion to date has focused on justifying DS as a valid way of doing research, and positioning or relating DS to "traditional" research approaches - instead of methodological exploration and elaboration of how and when DS research should be conducted in (opera- 
tions) management settings. This becomes apparent when comparing the relatively scarce literature on DS in OM, to fairly abundant (and often cited) methodological literature in the field of information systems (IS) (cf. Gregor \& Hevner, 2013; Gregor \& Jones, 2007; Hevner, March, Park, \& Ram, 2004; Peffers, Tuunanen, Rothenberger, \& Chatterjee, 2007), which is arguably at least a decade before $\mathrm{OM}$ in this respect.

With DS gaining traction in OM, the time is ripe for taking the next step in discussing DS as a methodology in OM. With the beachhead secured (cf. Holmström et al., 2009; van Aken et al., 2016), exploration of distinct features of DS in the field and research contexts of OM may begin. Looking at methodological contributions in the field of IS, open questions could include the structure of design theory (Gregor \& Jones, 2007) and its relationship to formal theory, the DS process in OM (Peffers et al., 2007), the relationship between subject of research and potential of contribution (Gregor \& Hevner, 2013), and writing and reporting DS research (Gregor \& Hevner, 2013). This is not to dismiss the work done in IS as unfit for OM (on the contrary, I draw upon it extensively in this dissertation), but rather to refrain from assuming it is readily applicable, and that $\mathrm{OM}$ does not need to undergo methodological introspection in this respect. In his editorial on OM research relevance, Ketokivi (2009) discusses the divergent views of the two camps discussed above - one point on which they differ is the theory-oriented scientist's interest in that which exists, in contrast to the practice-oriented scientist's interest in what could or should be. Thus, it would seem natural to begin answering the open questions of DS in OM through exploring the methodological underpinnings and implications of designs in terms of how they evolve from what could or should be, into that which exists.

This thesis sets out to explore the methodological implications of design maturity in $\mathrm{OM}$, based on the four appended design studies. The appended research papers describe OM designs in the context of construction (article 3) and asset maintenance (articles 1, 2 \&4) - with the common denominator being that they are all enabled by digitalization and ICT. The OM designs are arguably in different stages of maturity, with two of the designs (articles 1 \& 2) being in a very early stage, given that they have not yet been field-tested (cf. van Aken, 2004). These designs (where I was the designer) produce in-depth insight in the processes of problem (article 2) or opportunity (article 1) framing and design construction. Hence, this dissertation is partly also an introspective account of the relationship between designer and design, and the role of framing in translating what ought to be into what is. The other two designs (articles 3 \& 4) are more mature, with real-life implementations and materialized outcomes, producing insight in the processes of how outcomes are materialize in the intended context (article 3) and in contexts to which the design is transferred (article 4). Together, these papers create insight in how designs evolve from an initial idea, or problem, to being full-blown cross-context designs - and what knowledge is created in the process. 


\subsection{Research objective and questions}

The research objective of this thesis is to understand design maturity from a methodological perspective. In other words, to shed light on what we can learn from maturing OM designs, how this knowledge can be derived, and finally, how it could be structured and communicated. Considering the limited amount of DS research and methodological discussion in OM to date, the objective of the thesis could be characterized as methodological exploration. Hence, I will try to refrain from a prescriptive tone in my conclusions, which after all are based on (just) four designs, arguably just and just covering the (proposed) design maturity spectrum. This being said however, they do cover the spectrum - which allows me, based on my research, to offer a descriptive account of how research can be conducted in the different stages of design maturity and how it leads to new knowledge, which contributes to OM theory. Given the research objective, the first question in need of an answer is:

\section{$R Q 1 . H o w$ can design maturity be evaluated?}

This question is answered based on a review of previous research, largely from outside the field of OM. In the findings-section the answer is further refined based on the conducted empirical research. While there is a number of more or less explicit process models in methodological DS discussions in different fields (e.g. Holmström et al., 2009; Peffers et al., 2007; van Aken, 2004), they all tend to be contribution-centric in the sense that the desired knowledge is predefined, and the process leading to that knowledge is elaborated. In contrast, this thesis is built on the premise that different types of knowledge are created in different phases of the design's lifecycle, which prompts a revisit of the very foundations of DS (Simon, 1996). Once design maturity has been pinned down, the appended articles shed light on what knowledge is created in the different stages of design-maturity, providing an answer to the second research question:

$R Q 2 . \quad$ What kind of knowledge is created in different stages of design maturity?

Again, there is previous work related to this question, mainly outside the field of OM, which provides a good starting point, against which to reflect the research reported in the articles. Further, based on the conducted research I will be able to discuss what methods would seem suited for extracting the knowledge, and how designs should be conceptualized in the different stages of design maturity. Based on this reflection I expect to reach the objective of the thesis, through being able to chart the crude outlines of how what ought to be becomes what is, and what we can learn in the process, simultaneously addressing the great divide in the field of OM (cf. Ketokivi, 2009).

\subsection{Empirical context(s)}

The empirical contexts studied in the articles which comprise this thesis, could be considered wildly different, as construction and maintenance differ in several important aspects. Where the former is concerned with creating something that 
does not exist, the latter with maintaining what has already been built. The former emphasizes project over process, while the latter emphasizes process over project. Despite their differences, both are characterized by an operating environment of significant variability, complexity and uncertainty (cf. Colen \& Lambrecht, 2013; Dubois \& Gadde, 2002b; Elfving, Ballard, \& Talvitie, 2010; Erkoyuncu, Durugbo, \& Roy, 2013).

From an operations management perspective variability, complexity and uncertainty tends to be associated with inefficiency and waste (Bowen \& Youngdahl, 1998; Seddon, Donovan, \& Zokaei, 2011), as the first response is to hedge operations against these through buffers, and to some extent bear the risk of failed coordination. The second response to coping with variability, complexity and uncertainty is through increasing the flow and processing of information (Galbraith, 1974; Sampson \& Froehle, 2006; Tushman \& Nadler, 1978), improving the organization's responsiveness and agility. A key enabler for the second response is information- and communication technologies (Kowalkowski, 2008), which are not only changing how organizations work internally (Orlikowski, 2000), but also how organizations interact (Brax \& Jonsson, 2009; Hadaya \& Pellerin, 2010; Kowalkowski \& Brehmer, 2008) and create value (Oliva \& Kallenberg, 2003; Ulaga \& Reinartz, 2011).

As digitalization advances, more and more activities, resources and knowledge can be digitally represented, enabling more elaborate and extensive information flows, driving more efficient and effective operations (Wee, Kelly, Cattel, \& Breunig, 2015). Amounting up to a present and future where digitalization is driving a profound change in how companies cooperate and compete (Porter \& Heppelmann, 2014). This is the shared context and common denominator of my doctoral research; I explore designs (brought into a varying degree of maturity), which explore, test and elaborate new ways of doing things, of operating, based on data, made available by digitalization, and enabled by information and communication technologies.

\subsection{Scope and structure of the thesis}

Considering scoping, one of the key learnings, which has stuck with me from my graduate course in systems engineering, was that when defining something, you need to be talking about what something is - rather than what it isn't, and what it does - rather than what it doesn't. This thesis is about design science in OM, and specifically explores the creation of knowledge through designs. The findings of this thesis are to be considered inclusive, as the whole truth is likely beyond the four designs elaborated in the research papers that comprise this thesis. Finally, I also note that there is a contextual bias in the conducted research, as all studied designs represent new ways of doing things, enabled by digitalization, in B2B business contexts, ruling out all but speculative claims on applicability in e.g. B2C operations.

This concludes the introduction, where I have sought to position the thesis in the general, academic discussion by stating where I perceive a lack of 
knowledge, and how I intend to address this perceived gap. I also briefly summarized the empirical contexts of the appended research articles, relating them to greater societal and industry trends. In section 2, I will begin by exploring the methodological foundations design science, relying mainly on Simon (1996), with the objective of outlining a maturity view of design. I will then extend this discussion to encompass questions of knowledge creation and structuring. Finally, I will review the scarce previous literature on DS studies in OM. In section 3, I will briefly discuss the philosophical foundations for design science, further; I will present and elaborate on the methods employed in the research articles papers.

In section 4, I present a new framework on design maturity, to which I relate the findings in the research articles (RQ1). I then discuss what knowledge the articles create (RQ2), as a function of design maturity. I conclude section 4 by reflecting my findings on maturity and knowledge against previous DS studies in OM. Finally, in section 5, the implications of the thesis are discussed, arguing for a maturity-based foundation for the upcoming DS methodological debate in $\mathrm{OM}$ - in an attempt to avoid a future where design scientists have to choose whether they are with practice or theory (cf. Peffers, Tuunanen, \& Niehaves, 2018). In section 5 , I also discuss a number of methodological guidelines arising from my work, and identify issues, which will spark future methodological debate within OM. Finally, Appendices 1-4 include the original research articles, based on which this thesis is built. 



\section{Literature review}

Building on the foundation of the sciences of the artificial (Simon, 1996), DS aims to produce knowledge through design artifacts and the process of their creation and implementation (van Aken, 2004). In OM the design artefact is characterized as a management intervention (Denyer, Tranfield, \& van Aken, 2008), often framed as a solution to a problem faced by management (Holmström et al., 2009). Knowledge created through design artefacts contain the "what" in the solution itself, and most importantly the "why" as the solution rationale. Further, the implementation of design artefacts answer the questions of "whether" and "to what extent" something works, which then feeds back to solution refinement (Holmström et al., 2009). In this section, I will review prior (mainly methodological) literature in an attempt to build a foundation for answering the research questions. The focus of this review will be on what designs are, and what we can know about them, and based on them.

\subsection{Understanding the artificial through design}

The word design expresses an interesting duality in the sense that design can be both something that is, and something that one does (Hevner et al., 2004; citing Walls, Widemeyer, \& El Sawy, 1992). In this section, I focus on the prior - on how designs can be seen and understood with the intent of producing novel understanding of the context in which they are embedded. I will however, at several occasions, return to this duality, pointing out how design (as a process) is reflected in the design (as artifact) - and how that which is may have emergent properties, affecting what we do (Cooren, Thompson, Canestraro, \& Bodor, 2006). In the following section (section 2.1.1), I discuss what (artificial) designs are and how they are described, focusing on the relationship between problem/opportunity and solution - where one induces the other. I then briefly discuss two special cases of design - (1) transfer of design from one context to another (implying strong problem and solution definitions) in section 2.1.2, and (2) exploration through design (section 2.1.3) which denotes situations where both opportunity and solution definitions are weak. Finally, in section 2.1.4, I conclude by discussing how a design, as an (potentially emergent) artefact, matures along with having an increasing real impact. 


\subsubsection{The nature of designs}

The purpose of design science is the creation of new knowledge through studying design, both as a (potentially immersive) process, and as a manifestation of embedded purpose. Consequently, one would expect that how design scientists should describe their designs would be a widely debated issue. Yet there is scant prior research that would have concentrated on debating this specific issue, lest present normative guidelines on how, exactly, designs should be described in order for them serve the purpose of design science. In order to create a sound foundation for answering RQ1 in this thesis, I consolidate prior research exploring this issue, mainly relying on research from outside the domain of OM.

In Sciences of the Artificial, Simon (1996) distinguishes between the natural and the artificial, discussing how we could attempt to understand and create knowledge about latter, and how this on some points stands in contrast to the same endeavor regarding the former. In the quest for understanding and creating knowledge, the natural and artificial, however, share the same descriptive objective of offering a simple explanation of the complex (Simon, 1996). This also serves as a guiding question for the upcoming discussion on the nature of artificial designs - how do we crate simple descriptions of presumably complex designs, hence making them understandable?

The first clue as to the nature of designs can be elicited by asking what sets a design, or what is generally considered a design (e.g. a bridge), apart from that which is not considered a design (e.g. a rock) - or can everything be seen as design? Both are enabled and constrained by the natural forces and laws of the universe (Hevner et al., 2004; Simon, 1996; van Aken, 2004), so differentiation is not to be found there - neither can we say that the natural would be simple in contrast to the complex artificial, as the opposite argument is often more appealing (Simon, 1996). In conclusion, Simon (1996, p. 5) states that in contrast to the natural, the artificial is "synthesized (though not always with full forethought) by human beings" and it "may imitate appearances in natural things while lacking, in one or many aspects, the reality of the latter".

A perhaps more important distinction however, lies in the emergence of that which is considered. Whereas the natural emerges spontaneously, brought into existence by chance, as a result of random trial and error, that which is designed emerges purposefully, brought into existence by conscious effort, as a result of selective trial and error (Simon, 1962, 1996). What sets the artificial apart from the natural is thus the implied existence of a designer, which is able to conceive how things "ought to be" (Simon, 1996, p. 4), and hence impose purpose - beyond that of mere existence - on that which now becomes design. The remainder of this section is dedicated to exploring different, complementary ways of describing designs, beginning with design as purpose, moving on to design as structure and design as behavior, and concluding with design as emergence.

\section{Design as purpose}

"Solving a problem simply means representing it so as to make the solution transparent” (Simon, 1996, p. 132). Apart from conveying Simon's essential 
view that designs emerge in response to a perceived need to change one's environment, as discovering the means to a predetermined end, this quote highlights two important aspects of viewing designs as manifestations of purpose. The first aspect being that design purpose is a matter of representation, where "every problem-solving effort must begin with creating a representation for the problem - a problem space in which the search for the solution can take place" (Simon, 1996, p. 108). The significance of problem framing has been acknowledged ${ }^{3}$ by design scientists (Hevner et al., 2004; Holmström et al., 2009), and highlighted in empirical design research - also in the research articles comprising this thesis. Related to this point, Groop et.al. (2017) found that, especially when multiple stakeholders are involved, different representations of the problem may, and typically will lead to different, sometimes conflicting solutions (Jelinek et al., 2008), and by extension refined designs (Holmström et al., 2009).

The second aspect highlights that problem solving seldom starts from a clean slate, as any designer tends to be pre-equipped with knowledge of a set of means, which leads to a temptation to frame the problem so that it can be solved by known means (Holmström et al., 2009). While this view would imply that there are no truly novel solutions, this is not the point, nor is it accurate, as Simon (1996, pp. 210-211) reasons in contrast to Plato's notion that all learning is remembering. The point of highlighting this aspect is rather that problem representation is a reflection of the designer, reflected in the design. A quote from Pfeffer \& Sutton's (2006, p. 3) piece on evidence-based management illustrates this point well: "The old saying "To a hammer, everything looks like a nail" often explains what gets done".

This leads us to the other side of the coin, as Holmström et.al. (2009) argue that, complementing a problem- (Simon, 1996; van Aken, 2004) or need-driven (Hevner et al., 2004) approach to design science, an equally viable starting point is that of a solution-driven process. Here the design is to some extent given, and the search process aims to identify problems, or opportunities, where the design can be leveraged. The basic setup is still expressed in terms of means and ends, however, it inverts to discovering, or creating "multiple new ends that could not have been foreseen at the beginning of the process" (Sarasvathy, 2003, p. 214). The distinction between problem- and solution-driven approaches is far from clear cut, as noted by Sarasvathy (2001): "human imagination and human aspirations influence each other and reshape one another continually, both directly and through economic artifacts". However, both imagination and aspiration are vehicles of purpose, explanations on why designs come into being.

Further, in terms of understanding the influence of problem (and solution, as per the argumentation above) representation on design, Simon (1996, p. 131) notes that "we are still far from a systematic theory of the subject - in particular, a theory that would tell us how to generate effective problem representations". Simon (1996, pp. 131-134) mainly discusses effectiveness of representation in

${ }^{3}$ For an example of this issue on a societal scale, see Simon's (1996, p.141-143) recount of the "Marshal Plan" implementation. 
terms of how fast or easily a solution to a complex problem is derived in the mind of a problem-solver. A complementary view arising from bounded rationality in organizational settings, is one where the effectiveness of problem representation is determined by how well the representation is able to align the views and efforts of the actors involved in the design process (cf. Simon, 1996, pp. 139-141).

\section{Design as structure}

For readers with an engineering background, the first association with the word design is probably somehow related to structure, or physical form. In accord with this, a description of design structure ideally conveys what the design is, for the purpose of design reproduction (Simon, 1996). When moving from the technical domain to the economic and organizational, the structure of design becomes something far more abstract. Simon (1962, 1996) approaches the structure of design from the perspective of complexity, arguing that (1996, p. 215) "most of the complex structures found in the world are enormously redundant, and we can use this redundancy to simplify their description". In other words, we can seek to understand complex structures through understanding their parts.

A simplified description of complex systems, to which many complex systems lend themselves (Simon, 1996, p. 207), tends to be hierarchical and near decomposable. Hierarchy in this connection means that complex systems will exert a parts-within-parts-within-parts structure. Examples would include employeedepartment-firm-industry-economy or cogwheel-transmission-propulsion-vehicle-transport. With proper decomposition, hierarchies enable us to "build nearly independent theories for each successive level of complexity, but at the same time, build bridging theories that show how each level can be accounted for in terms of the elements and relations of the next level below" (Simon, 1996, p. 172).

The question is then, what is "proper" decomposition and how is it derived? The key to this according to Simon (1996) is in defining hierarchy based on the intensity of interaction between parts (or actors). Here, system structure is defined based on weak interaction of its constituents over sub-system boundaries, in contrast to a strong interaction within sub-systems. Weak (enough) interaction provides the premises for near-decomposability, a property of hierarchical (complex) systems with two important implications for building an understanding of these systems (Simon, 1996, pp. 197-198). First, in the short run, the behavior of a sub-system is "approximately independent" of the behavior of other sub-systems. Second, in the long run, the behavior of a sub-system depends "only in an aggregate way" on the behavior of other sub-systems.

In a similar vein as interaction implies a conceptually intertwined relationship between understanding design as structure and as behavior, there is an indication of kinship between structure and purpose, as the "proper" decomposition is essentially a representation of structure. Related to this, Simon (1996, p. 128) notes that "there may exist alternative feasible decompositions of radically different kinds”. Simon (1996) continues by illustrating this through how work 
in business organization can be decomposed in several different ways (e.g. business functions, business processes, business projects etc.), although the subject of study (and how it behaves as a system) remains the same. Also Jelinek et.al. (2008, p. 318) recounts different ways of decomposing organizational structure, noting that; "our descriptions matter, for they direct our attention and expectations".

Whereas the structure of complex systems can be understood in different ways depending on how the design hierarchy is defined, the border between design and environment is often treated less ambiguous, or even implicit. Simon (1996, p. 6) discusses this border as "a meeting point - an "interface" in today's terms - between an "inner" environment, the substance and organization of the artefact itself, and an "outer" environment, the surroundings in which it operates". While this border can be problematized, and I later do problematize it, this is where design can be understood as behavior.

\section{Design as behavior}

At the interface between design and environment, design purpose materializes, as the design interacts with its environment. Studying the behavior of the design at this interface holds potential to reveal knowledge of not only design purpose, but also insight in design structure (Simon, 1996). Further, just like complexity in structure can often be reduced through hierarchical description, seemingly complex behavior of a design "is largely a reflection of the complexity of the environment in which it finds itself" (Simon, 1996, p. 52). In other words, behavior can presumably be described as a set of interdependent rules (or mechanisms) which (despite relative simplicity), triggered by different environmental stimuli, may together create complex outcomes.

Whereas the environment evokes behavior, design structure not only enables behavior, but also limits it. As expressed by Simon (1996, p. 12): "the behavior of the system will only partly respond to the task environment; partly it will respond to the limiting properties of the inner system". Based on the discovery of the interdependent rules that add up to a description of design behavior, we can thus seek to deduce what the design is intended to do, what the design can do, and to some extent, what it cannot do. This leads Simon to conclude that "we might look toward a science of the artificial that would depend on the relative simplicity of the interface as its primary source of abstraction or generality." (Simon, 1996, p. 9). However, behavior unfolds over time, which has implications for creating design knowledge based on behavior. This leads us to questions of how stable and sustainable design purpose, structure and by extension behavior is, which prompt a fourth approach to describing designs - that of design as emergence.

\section{Design as emergence}

"Cognitive limitations on our rationality allow us to build artifacts that achieve only local optima at best; yet, our artifacts can endure over time by learning to adapt to contingencies and sometimes even exploit those contingencies for their own survival and prosperity" (Sarasvathy, 2003, p. 205). The fourth approach 
in describing designs is that of design as emergence. This approach describes design as a melting pot, where, driven by a changing environment, purpose is adapted, structure is regenerated or reproduced and behavior is learned. While this approach is less explicit (but present) in the extant literature (cf. Gregor \& Jones, 2007), Simon (1996, pp. 210-215) touches upon emergence in his discussion on self-reproducing systems. He relates his observations to the survival of adaptive organisms, arguing that "adaptiveness" is rooted in the ability to find the difference between a desired state of affairs, and a current state of affairs, and then to "find the correlating process that will erase the difference" (Simon, 1996, p. 210).

Related back to design as that of the artificial, I will argue that many of the OM designs constructed today have emergent properties - where structure or behavior is not strictly predefined - or designed - but rather unfolds over time in accord with a changing environment. Considering the study of emergence, which is also very relevant in design transferability, there are two important concepts, which are central in understanding design as emergence. The first is the existence of a meta-design, a common denominator - a design that serves as the foundation and facilitator of the emergent designs. Van Aken (2004, p. 227) touches this in his discussion on design exemplars, which he defines as "a general prescription which has to be translated to the specific problem at hand; in solving that problem, one has to design a specific variant of that design exemplar". In description of a meta-design, a connection can be drawn to design patterns - which are documented solution designs or means-ends propositions, proven to hold in contexts other than the one in which they were developed (Holmström et al., 2009). The second is a tendency of design emergence to be path-dependent (David, 1985; Pandza \& Thorpe, 2010; Sarasvathy, 2003). Both of these are conveyed in Simon's (1996, pp. 212-215) discussion on ontogeny recapitulating phylogeny. Design as emergence also makes the distinction between design and designer ambiguous, as a part of the designer is in a way etched in the design (Cooren et al., 2006), or a design is a result of subsequent design efforts by different designers (organizational use, perspectives and participants in Sein et.al. (2011)).

Van Aken (2004, p. 241) discusses emergence in organizations through the following analogy; "an organization can be compared with a garden, as artefact created through the designs and hard work of the gardener and as natural system developing under the influence of sun, rain, soil conditions, insects etc." He then continues with noting that "in some gardens the gardener tries to control natural development as best as he/she can, while in others the gardener leaves more to Mother Nature" (van Aken, 2004, p. 241). These passages also capture the basic premise of design as emergence, in the sense that a good designer will know when it is best to leave something to nature - and how, through the design, one can make sure that nature will take care of it. "Nature" in these organizational settings arguably primarily consist of people, whose interactions constitute the organization (van Aken, 2005), making behavioral research an integral complement to design research (Hevner et al., 2004) in understanding the emergent properties of designs. 
In the field of information systems, Sein et.al. (2011) discuss guided emergence as a principle related to reflection and learning in what they term Action design research. The authors outline emergence as the consequence of a reciprocal design process, where artifact and organization shape each other, "reflected" in the resulting design (Sein et al., 2011, p. 44). A few years earlier, in the same field, Gregor \& Jones (2007, p. 326) postulate that; "we believe that the lack of theories about IT artifacts, the ways in which they emerge and evolve over time, and how they become interdependent with socio-economic contexts and practices, are key unresolved issues for our field". They continue to stress that the issue "will become even more problematic in these dynamic and innovative times" (Gregor \& Jones, 2007, p. 326). A similar line of argumentation is arguably applicable to the field of OM, in light of the increasing significance of behavioral research in OM (Bendoly, 2006; Bendoly, Croson, Goncalves, \& Schultz, 2009; Bendoly, Donohue, \& Schultz, 2006; Gino \& Pisano, 2008). This is also supported by Romme (2003), who argues that studying emergent properties of (organizational) designs through complexity theory is a promising area for future work.

\subsubsection{Design transferability}

"If natural phenomena have an air of "necessity about them in their subservience to natural law, artificial phenomena have an air of "contingency" in their malleability by environment" (Simon, 1996, p. xi). While Simon in The Sciences of the Artificial is preoccupied with exploring problem-driven design, scholars in the fields of entrepreneurship and OM have occasionally highlighted the equally viable approach of solution-driven design (Holmström et al., 2009; Sarasvathy, 2001). As noted in the previous section, the distinction between problem- and solution-driven research is far from clear-cut, arising from the degree of ambiguity in how the problem or solution is defined. Akin to the distinction between exploration and explanation discussed by Holmström et.al. (2009), one can distinguish between design exploration and -exploitation, where the latter is the subject of this section, and contrary to what Holmström et.al. (2009) posit, also in the scope of the design scientist.

Problem and solution are tightly intertwined, and whereas design exploration denotes research on weak problem- and solution definitions, design exploitation builds on strong problem- and solution definitions. Once a design has succeeded in bringing about change in the context in which it was conceived, the question arises whether the design could bring about a similar change, in a different (but similar) context. These similar contexts then form a limited range of contexts in which the design brings about the intended outcome, defining what van Aken (2004) calls an application-domain. With design purpose rooted in context, the generalizability of a design becomes a question of how well the design transfers to other contexts (van Aken, 2005), the answer to which gradually outlines the generic (meta-) design, based on which context-specific applications are built (van Aken et al., 2016). On a market or industry scale, design transferability in terms of learning from the successful designs of other firms 
plays a significant role "in the gradual evolution of an economic system composed of business firms" (Simon, 1996, p. 48).

\subsubsection{Exploration through design}

Whereas solution-driven design science, aiming for design exploitation deals with strong problem and solution definitions, solution-driven design science done for the sake of exploration starts with weak problem and solution definitions. Weak in this sense does not mean that the designer goes about bringing change to the world without any pre-existing notion of what the opportunity/problem or the solution would be, but rather that problem and/or solution are defined on a domain-level. An illustrative example here would be an explorative study of introducing RFID in a supply chain (cf. Ala-Risku, Kärkkäinen, \& Holmström, 2003; Kärkkäinen \& Holmström, 2002), where the purposes of a type of technology (-solution) (RFID) is explored in the (problem) context of supply chains.

Despite outlining that exploration through design necessarily has (at least) a weak problem and/or solution definition, we need to highlight an exception in this rule. A designer can start from a clean slate with respect to problem and solution; however, in this case the designer is typically referred to as an entrepreneur. Research on entrepreneurship is an established field, which has also embraced design science (Sarasvathy, 2001, 2003) to some extent. Removing the solution and the problem from the equation however puts the focus on what is left: or to be more precise, what exists before the solution and the problem: the designer. Sarasvathy (2003, p. 218) captures this in her elaboration on entrepreneurship as a science of the artificial "our designs are contingent on our imagination [...] given who we are, what we know, and whom we know, we can build a variety of effectual artifacts by focusing on what we can do, rather than continually worrying about what we ought to do".

\subsubsection{How designs mature}

"Artificial things are often discussed, particularly when they are being designed, in terms of imperatives as well as descriptives" (Simon, 1996, p. 5). Building on this quote, we could characterize the design process as one of converting imperatives to descriptives, where what ought to be is gradually transformed into what is. The maturity of a design can be evaluated in a similar vein, where a desire to change the state of things eventually results in a solution which changes the state of things. However, as a concept, maturity carries the built-in assumptions of unidirectionality and finality - both of which can be questioned based on prior research presented in this section. I do this by distinguishing between problem and solution maturity (Gregor \& Hevner, 2013).

First, design unidirectionality can be questioned as design is commonly depicted as a highly iterative process (Hevner et al., 2004; Holmström et al., 2009), where a solution is gradually improved when reflected back against the 
(ill defined) problem (Romme, 2003), driving an iterative refinement of the design (Peffers et al., 2007). Supporting this notion (or perhaps founding it), Simon (1996) discusses design as an activity where problems and solutions can potentially be broken (decomposed) into smaller semi-independent design challenges, and where arriving at a solution is the result of an iterative searchand selection process. Assuming that these iterations may involve reverting to an earlier stage of the design (in order to try an alternative path), the unidirectionality of design can be questioned. However, in a juxtaposed view Simon also characterizes search processes not as processes for seeking solutions, but rather as "processes for gathering information about problem structure that will ultimately be valuable in discovering a problem solution" (Simon, 1996, p. 127). Merging these views, allow us to discuss maturity as a unidirectional concept, in the sense that whenever the design, or solution, takes a step back, the understanding of the problem takes a step forward.

Second, design finality can be questioned, as design is, by some, argued to be a continuous process, and designs by their nature "unstable". Simon (1996, p. 162) explores these aspects, noting that "a paradoxical, but perhaps realistic, view of design goals is that their function is to motivate activity which in turn will generate new goals". Further, as discussed in section 2.1.1, designs with emergent properties are by their nature unstable (or incomplete). For designs with emergent properties, the involvement of one designer may cease, only to be followed by the design actions of the next designer - "what we call "final" goals are in fact criteria for choosing the initial conditions that we will leave to our successors" (Simon, 1996, p. 163). Adaptive designs with emergent properties may not have a "final" mature state. The understanding of such designs can however, if not have a final state, at least be argued to converge. So whereas design maturity in terms of purpose, structure and behavior can be evaluated against a fixed environment, design maturity in terms of emergence can be evaluated against different and changing environments.

With these two rhetorical issues settled, based on the prior work presented in the previous sections, we can sketch the following representation of how designs are born, and how they mature (Figure 1). Before the design, before even a hint of problem or solution exists, there is only the primary designer - harboring the seed of framing, which begins to grow at the instance the designer comes across something that ought to be. While framing and re-framing both solution and problem (or opportunity) the designer begins translating behavior to structure and vice versa, perhaps considering emergence, gradually giving birth to the design artifact. Once the artifact has come into (at least partial) existence, it is subjected to context (perhaps gradually). This reveals not only its effectiveness, but also unexpected emergent properties - which may prompt re-design (Sein et al., 2011). Emergence comes about when the design is reliant on (boundedly rational) users, who impose their own frames of problem on the solution, leading to unintended use and outcomes. Once the design has produced satisfactory (or as good as it gets) outcomes in the context it is designed for, the design may spark interest in other similar contexts, where a similar problem (or opportunity 
exists). Provided that the primary designer is not involved in the transfer, a secondary designer (with possible differences in framing compared to the primary designer) adapts the design to his or her context through a similar process undertaken by the primary designer, re-using aspects of the original solution, to the extent they are available and seem to be applicable and appropriate. As the design produces (or does not produce) satisfactory outcomes in the secondary contexts, the limits of design applicability are gradually mapped and a generic conception of the design emerges (on top of which further context-adaptations can be developed).

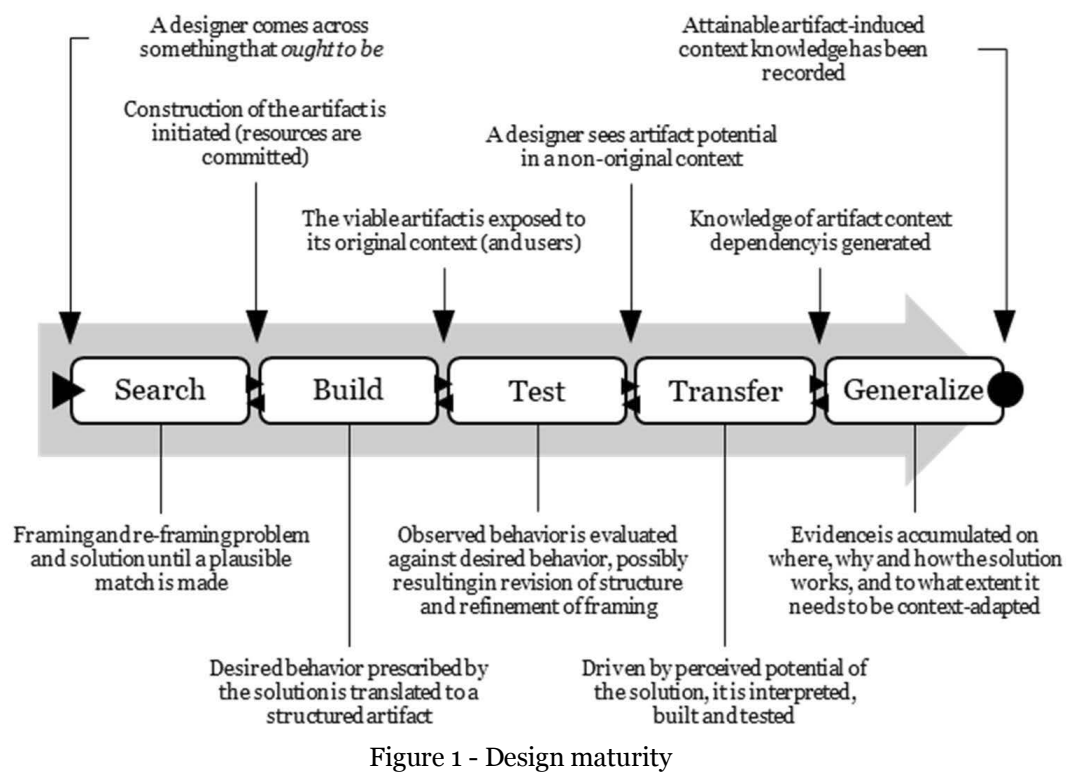

\subsection{Creating knowledge through design}

After probing different aspects of designs and their properties, we return to what makes design science a de facto science. Science is arguably concerned with creating knowledge based on which we can understand the world that surrounds us. In contrast to the natural sciences, which is concerned with creating knowledge on what is, design science is concerned with creating knowledge on what ought to be (Simon, 1996) - based on the premise that, through human agency, persistence and ingenuity, what ought to be will become what is. The pragmatic basis of design science (Romme, 2003) is thus concerned with creating "knowledge to be used in designing solutions, to be followed by design-based action" (van Aken, 2004, p. 226).

\subsubsection{Articulating design knowledge}

While Simon (1996), in his pioneering work, argues for the legitimacy and need for a science of the artificial, he does not offer much detail on how theory concerning and deriving from artifacts should be articulated (Gregor \& Jones, 2007). Design scientists seemingly agree (cf. Gregor \& Hevner, 2013; 
Holmström et al., 2009; Romme, 2003; van Aken, 2004; van Aken et al., 2016) that design knowledge, just as any theory (Bacharach, 1989), is captured in testable (and refutable) propositions. As design-propositions arguably form the truth claim, and thus the essence of a design theory, we shall return to them shortly. First however, we will take a broader look at design knowledge, as van Aken (2005) note that design propositions (referred to as technological rules in the cited article) are necessarily accompanied by thick descriptions, which may "fill an article, a report or even a whole book" (van Aken, 2005, p. 23). Gregor \& Jones (2007) arguably explore what these thick descriptions entail, as they elaborate what they call the anatomy of design theory (in the field of IS).

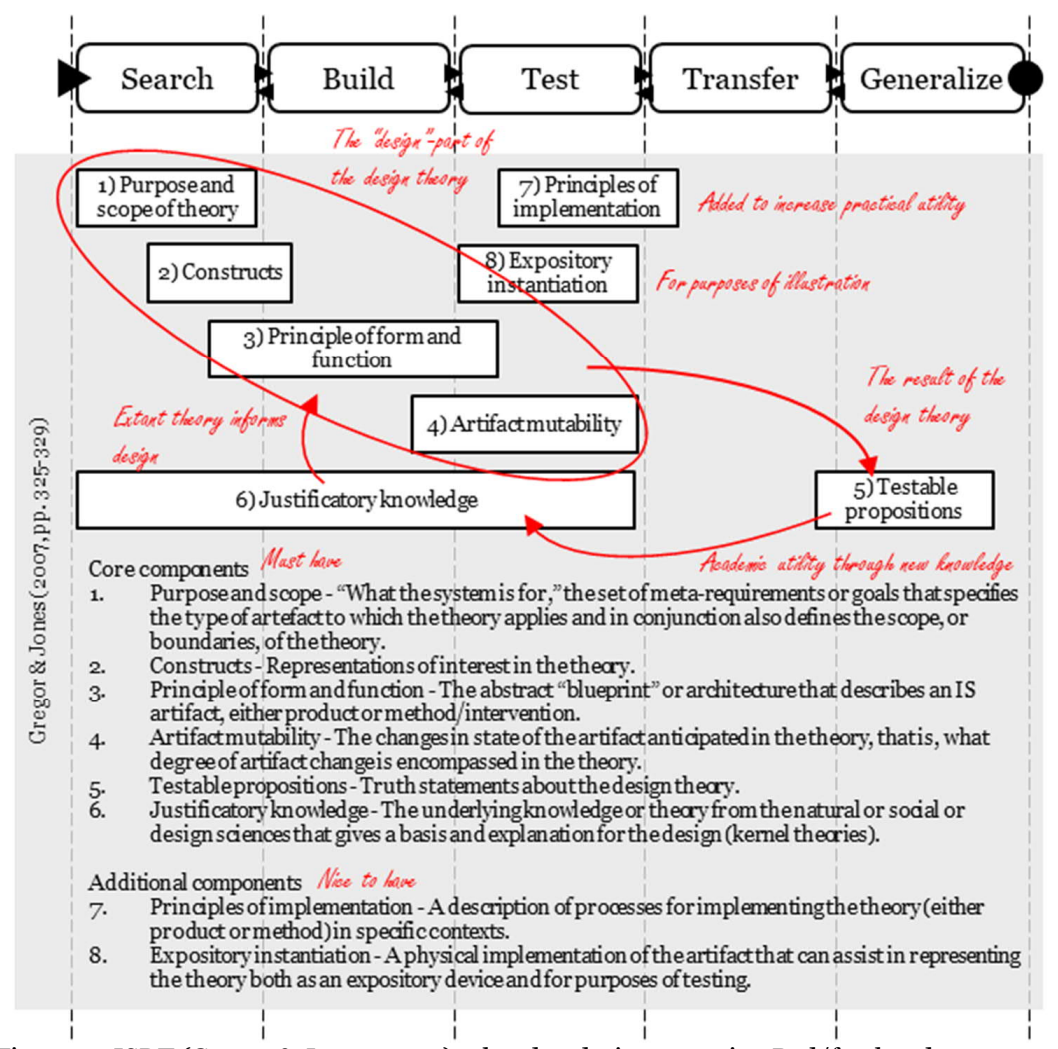

Figure 2 - ISDT (Gregor \& Jones, 2007) related to design maturity. Red/freehand text represents my interpretation of the source

Gregor \& Jones (2007) identify six core components and two additional components, which together constitute an Information Systems Design Theory (ISDT). The components can be related to the above discussion on the nature of designs. Design as framing is conveyed through purpose and constructs, possibly inspired by justificatory knowledge and providing the language for expository instantiations - the components relating to how a problem/solution is seen, discussed and communicated. Design as structure and behavior can be present as defined relationships (hierarchy) and interactions amongst constructs, but would probably be elaborated in principles of form and function. Design as emergence is arguably relatable to artifact mutability, but could also 
be related to principles of implementation, for example if the design implementation contains path-dependencies. While these components arguably, or perhaps ideally, convey a thick description of a given design, the gist of design knowledge, is condensed into testable propositions, i.e. truth statements about the design theory.

In their inaugural essay of the design science department of the Journal of Operations Management, van Aken et.al. (2016, p. 3) state that; "the core product of DSR is the well-tested, well-understood and well-documented innovative generic design that has been field tested to establish pragmatic validity". Van Aken et.al (2016) see testing as a prerequisite for understanding the mechanisms producing the outcomes sought through the design, and documenting as the prerequisite for communicating design-knowledge, relevant to practitioners. Proponing the CIMO-logic (Denyer et al., 2008), they continue by stating that "the generic design is supported by a design proposition, producing insight on where and how the generic design is to be used in the field" (van Aken et al., 2016, p. 3).

\subsubsection{Design propositions}

Testable propositions figure in some form throughout the methodological discussion surrounding design science, albeit with different labels and different formulations. The first, and perhaps most general expression is means-ends propositions (Holmström et al., 2009), derived from the work of Simon (Simon, 1996). From a pragmatic point of view, means-ends propositions would convey the "appropriate means to reach designated ends" (Simon, 2000, p. 72), and thus, as such leaves much to be clarified by the thick description. In their work, Holmström et.al. (2009), elaborate the form of means-ends proposition during different phases of design research, moving from (1) exploration of viable means-ends combinations, to (2) documenting successful means-ends to propositions, to (3) testing for means-ends proposition (between context) transferability to (4) theoretical formalization of means-ends. Holmström et.al. (2009) do not discuss the formulation of means-ends propositions in detail, but argue that "understanding how means-ends propositions develop across the four phases of research holds the key to linking exploratory and explanatory research" (Holmström et al., 2009, p. 77).

The second term frequently used is technological rules (Gregor \& Hevner, 2013; van Aken, 2004, 2005; van Aken et al., 2016), based on the work of Bunge (1967), defined by van Aken as "a chunk of general knowledge, linking an intervention or artefact with a desired outcome or performance in a certain field of application" (van Aken, 2004, p. 228). Van Aken (2004, p. 228) continues by specifying that general in the above definition means that the rule is a "general prescription for a class of problems", making it applicable beyond a specific setting, but limited to a "certain field of application". Pandza \& Thorpe (2010) criticize the use of technological rules in management research on the grounds that they would imply determinism, which is not feasible for designs (with emergent properties) introduced in social systems. This implication is however (in my 
view) addressed by van Aken (2004), as he specifies that technological rules in management tend to be of heuristic nature. Further, van Aken (2004) calls for field-testing and grounding of technological rules, which translates to unearthing the generative mechanisms, leading to more elaborate rules (van Aken, 2005). Apart from being field-tested, implicit in the definition above, van Aken (2005, p. 29) also notes that in order for a technological rule to be considered a design proposition (1) the dependent variable has to describe something of value to the organization, (2) the independent variable must describe something that can be changed.

The quest for generative mechanisms (van Aken, 2004) led to the third expression of design propositions, constructed according to the CIMO-logic (Denyer et al., 2008; van Aken et al., 2016), with its roots in social policy (realistic) evaluation (Pawson \& Tilley, 1997). The CIMO-logic is expressed as (Denyer et al., 2008, pp. 395-396); "in this class of problematic Contexts, use this Intervention type to invoke these generative Mechanism(s), to deliver these Outcomes(s)". Although the logic does not dictate the form of the design proposition (Denyer et al., 2008), it results in formulating design propositions which "contain information on what to do, in which situations, to produce what effect and offer some understanding of why this happens" (Denyer et al., 2008, p. 396). Denyer et.al. (2008) argue that this type of logical structuring also enables a realist synthesis (Denyer \& Tranfield, 2006) of research in fragmented fields where the applicability of results may be ambiguous.

The fourth expression of design propositions is design patterns (eg. Gregor \& Jones, 2007; Holmström et al., 2009), originating from influential pioneering work in architecture (Alexander et al., 1977). Design patterns can be expressed as documentations (Holmström et al., 2009) of demonstrated solutions to recurring problems (Dong, Zhao, \& Peng, 2009). The recurring nature of the problem here means that the problem is present in a range of contexts rather than being a within-context persistent problem. For these problems, design patterns offer generative solutions (Alexander, 1999), which is essentially the generalizable expert (means-ends) knowledge on top of which the in-context designer is able to build his or her (context-customized) solution. Apart from being generative, Alexander (1999) specified two additional essential features of design patterns (as an expression of pattern language). First, they have a moral component - which in the case of architecture is the creation of a living artificial environment. Second, they have the aim of creating morphological coherence - they should be formulated in a way that results in similar (but context-adapted) designs. The counterparts for these can be found in Denyer et.al. (2008, p. 394) who state that "the mission of a design science is a quest for improving the human condition"4, and in Gregor \& Jones (2007, p. 327; citing Walls et al., 1992) "there is a need to verify whether or not the design method results in an artifact that is consistent with the meta-design".

\footnotetext{
${ }^{4}$ I note however, that the lack of a shared moral component has also been discussed as a weakness of management research (Romme et al., 2015)
} 


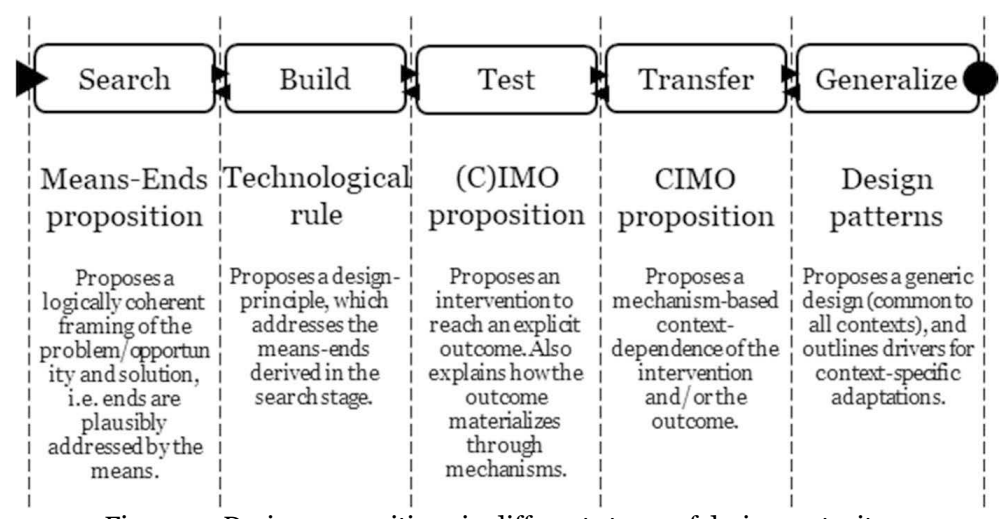

Figure 3 - Design propositions in different stages of design maturity

In summary, the different ways of formulating design propositions emphasize different aspects of the truth claim. These differences can be viewed through the CIMO-logic as follows: First, truth claims have a varying degree of context specificity, ranging from means-ends propositions, which can be practically devoid of context. At the other end of the spectrum, the CIMO-logic practically forces an explication of context. Second, truth claims have a varying degree of intervention specificity, ranging from a very explicit notion of intervention proponed by the CIMO-logic, to the heuristic nature of technological rules where the intervention is discussed in terms of "perform something like action X" (van Aken, 2004, p. 23). Another perspective is offered by design patterns, which defines the intervention through the smallest common denominator of demonstrated solutions to a recurring problem. Third, explicit inclusion of the mechanism in the truth claim is specific to design propositions constructed according to the CIMO-logic. However, as the distinction between context and mechanism (mechanisms are essentially embedded in context) is somewhat vague, it could be argued that the mechanism is (or at least can be) implicitly suggested through the way the context is framed. Fourth, truth claims communicate a varying degree of confidence in outcomes, ranging from fairly deterministic expressions, to treating intended and unintended outcomes (Orlikowski \& Gash, 1994) as equally important and interesting (cf. van Aken, 2005).

\subsubsection{Knowledge creation in the design process}

"Design science is inherently a problem solving process" (Hevner et al., 2004, p. 82), which in itself needs to be explained and improved (Simon, 1996). Despite degradation to an issue of "additional interest" in the inaugural essay of the design science department of the Journal of Operations Management (van Aken et al., 2016, p. 7), prior work emphasizes the importance of the process leading to a design artefact (Gregor \& Hevner, 2013; Holmström et al., 2009). Considering this, the scarcity of prior work on the design process itself is surprising, apart from a seeming agreement that it is iterative (Hevner et al., 2004; Holmström et al., 2009; Peffers et al., 2007; Simon, 1996) and largely tacit (van Aken, 2004) or inexplicable (March \& Smith, 1995). In organization studies, the 
design process is also characterized as inherently collaborative (Jelinek et al., 2008; Romme, 2003; van Aken, 2004).

In the field of IS, the process of design science research has received explicit attention from a number of scholars (cf. Österle et al., 2011; Peffers et al., 2007). Building on prior methodological work, Peffers et.al. (2007) present a nominal process for conducting DS research, which has gained traction both within and outside the field of IS. Aside of presenting a six step iterative DSR process of; (1) identify problem \& motivate, (2) define objectives of a solution, (3) design \& development, (4) demonstration, (5) evaluation and (6) communication, Peffers et.al. (2007) also highlight four different entry points of DS research. In contrast, the field of management has been preoccupied with positioning DS in relation to the established scientific praxis, manifested in work that seeks to relate DS to the process of knowledge creation (Holmström et al., 2009; van Aken, 2004), rather than explicating DS as a de facto "how-to" process for creating knowledge. This is arguably a reflection of design science seeking to justify its existence as a valid research approach in the field, followed by gradual success (cf. Jelinek et al., 2008; van Aken et al., 2016). In Figure 4, below, the discussed DSR process views are reflected against design maturity (Figure 1).

So, what knowledge is created during these processes? Gregor \& Hevner (2013, p. 344) note that "A DSR project has the potential to make different types and levels of research contributions depending on its starting points in terms of problem maturity and solution maturity". In developing their claim, they present a 2x2 where solution maturity and application domain (problem) maturity ranges from low to high, positing that there is a "research opportunity and knowledge contribution" (Gregor \& Hevner, 2013, fig. 3) in all but routine design, where both are high. Further, they distinguish between descriptive and prescriptive knowledge, but conclude that the remaining three quadrants may all potentially produce both. While Gregor \& Hevner list the "Situated implementation of artifacts" and "operational principles/architecture" as (less mature) knowledge contributions (Gregor \& Hevner, 2013, p. 342), both Holmström et.al. (2009) and van Aken (2004) clearly emphasize more mature knowledge ((novel) operational principles/architecture, mid-range or formal theory) as the principal knowledge product of design science. However, the processes discussed here all depict knowledge as something, which is the result of the process, rather than something that is shaped during the process - seeing design through maturity allows examining the latter perspective. 


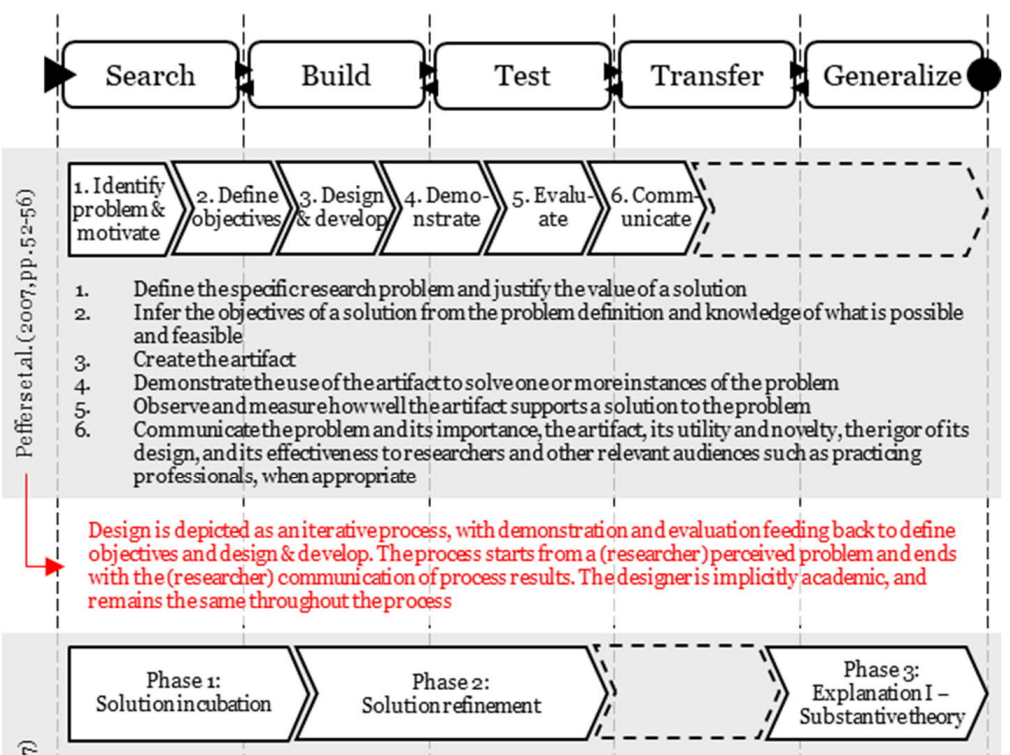

Phase 1. Framingtheproblem and developing the rudiments of a potential solution design. Solution designs aretechnical spedifications for solutions that areincomplete butdetailed enough to be implemented at least in a test environment

Phase 2.Therefinement phaseis a combination of designimprovements, implementation, and evaluation and often makesuse of themorefamiliarresearch designs and reasoning. However, in tryingto pinpoint the sources of the uninten ded consequences, abductivereasoningand further detectivework mayberequired.

Phase 3 . In phase 3 , the theoretical relevance of the solution designis established. This involves an examination and evaluation of theartifact from thethear etical, notpragmatic, point of view. The ultimategoal is similar to grounded theory: empirical examination of solution designs in multiple contexts turnsthesolution design into mid-range theory of practice.

Phase 4.(Devaid of design) Formal theories often developfrom substantivetheories as timeprogresses (Glaser \& Strauss, 1967), effectively linking Phases 3 and 4 . While both substantiveand formal theory can be considered to bemidd de-range (Glaser \& Strauss, 1967), formal theories are clearly aimed at broader generalizability, both in terms of thecretical abstraction and statistical generalizability.

Design is depicted as aniter ativeprocess, especially in thesolution refinement phase, duetothe wicked nature of problems in OM. Theprocessstarts either from a problem or a solution andends with thedevelopment of formal theory, which is arguably devoid of design. A practitioner designer stops after phase 2, whilethedesign scientist preferably covers all phases, with a minimum of phases 1-3.

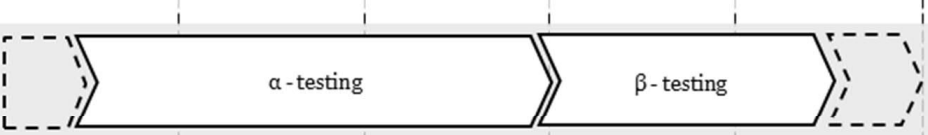

$a$ - testing. Research is initiated by theresearcher(s) interestedin developing technological rules for a certain type of managerial issue. The [managerial issue] is solved in closecollaboration with the local people. This development process can firstgo through a stage of ' $\alpha$-testing, i.e. analysis of the effectiveness of a certain rulein the original context

$\beta$ - testing, translating theruleto other contexts, having third parties useit, assess its effectiveness and makefinal improvements. In $\beta$-testing of managerial technological rules oneis inter estedin both driving and blockingmechanisms (instanceswheretherulefails areal so highlyinteresting). Itis especially this groundingin drivingand blockingmechanisms which will support thetranslation of the ruleto other contexts.

Thefocus is not on the design artefact, but rather thetechnol ogical rulethat the design artefact evokes. Theprocess startsfrom "ther esearcher(s) beinginterested in developingtechnological rules for a certain type of managerial issue", and ends onethederived rule(s) have been sufficiently tested. $\alpha$ and $\beta$-testing should preferably bed one by different researchers in order to "counteract the unrecognized defences' of the originator of therule, which may blind him or her topossibleflaws in its use".

Figure 4 - Design maturity related to design processes (Holmström et al., 2009; Peffers et al., 2007; van Aken, 2004). Red text partially represents my interpretation of the source 


\subsection{Contemporary design science research in OM}

The footprint 5 of DS in OM is still relatively small when compared for example to the field of IS, where it is safe to say that DS has established itself (Figure 5). Further analysis reveals that despite the limited footprint, DS in OM has rapidly made its way to the top tier journals in the field (Figure 6 and Figure 7), arguably aided by the establishment of the DS department at Journal of Operations Management (van Aken et al., 2016). In order to analyze the nascent body of OM DS literature, a slightly broader search ${ }^{6}$ (than the footprint search) was conducted, including the term "design theory" - as article 3 from this dissertation was missing in the footprint sample. The search, which focused on AJG OPS\&TECH journals, resulted in an initial sample of 59 DS articles in the field of OM.

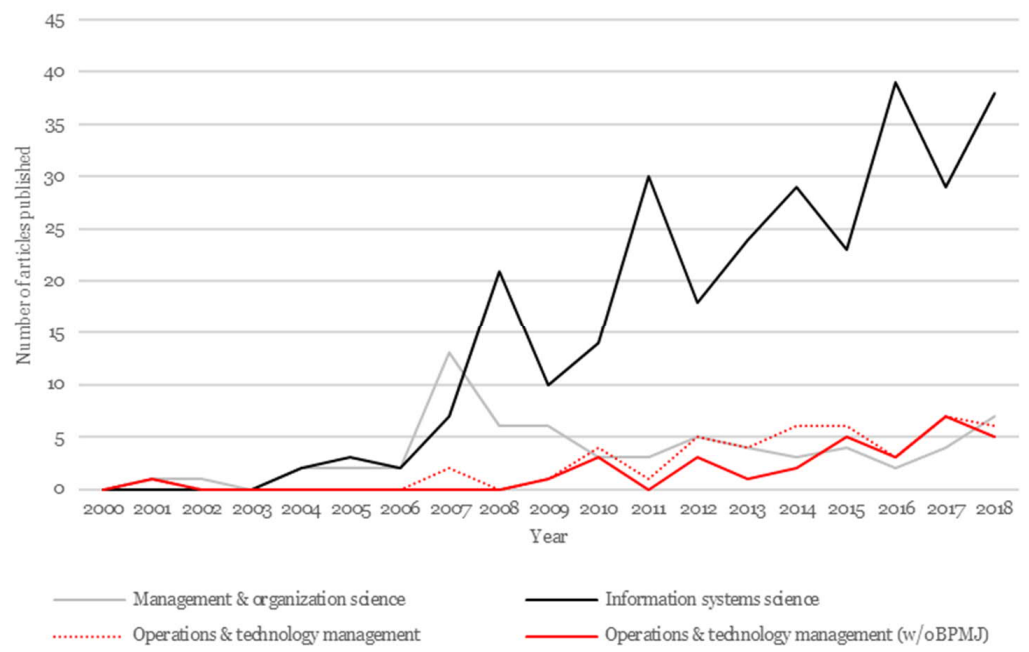

Figure 5 - Published design science articles per field7 2000 - 2018

The resulting sample underwent initial screening based on references to DS methodological work ${ }^{8}$, which reduced the sample to 39 articles ${ }^{9}$. Next, the title and the abstract of the remaining 39 articles was evaluated, leading to the exclusion of two further articles. Inspecting the remaining 37 articles revealed that

\footnotetext{
${ }^{5}$ The footprint was analyzed using the Scopus database (https://www.scopus.com), using the search term "TITLE-ABS-KEY ( "design science" )" which yielded a total of 3060 results, most of which were in the subject area of computer science. The articles were further classified based on the Chartered Association of Business Schools (https://charteredabs.org/) journal ranking field classifications, where the field of OM was represented by the category AJG OPS\&TECH.

${ }^{6}$ TITLE-ABS-KEY ( "design science" OR "design theory") AND ( LIMIT-TO ( SUBJAREA, "BUSI") OR LIMIT-TO ( SUBJAREA, "DECI") ) AND ( LIMIT-TO ( EXACTSRCTITLE, "Business Process Management Journal") OR LIMIT-TO ( EXACTSRCTITLE, "International Journal Of Operations And Production Management") OR LIMIT-TO ( EXACTSRCTITLE, "International Journal Of Production Economics" ) OR LIMIT-TO ( EXACTSRCTITLE, "International Journal Of Production Research") OR LIMIT-TO ( EXACTSRCTITLE, "International Journal Of Logistics Management") OR LIMIT-TO ( EXACTSRCTITLE, "International Journal Of Productivity And Performance Management") OR LIMIT-TO (EXACTSRCTITLE, "Computers In Industry") OR LIMIT-TO ( EXACTSRCTITLE, "IEEE Transactions On Engineering Management") OR LIMIT-TO ( EXACTSRCTITLE, "International Journal Of Project Management") OR LIMIT-TO ( EXACTSRCTITLE, "Journal Of Operations Management") OR LIMIT-TO ( EXACTSRCTITLE, "International Journal Of Physical Distribution And Logistics Management") OR LIMIT-TO ( EXACTSRCTITLE, "International Journal Of Technology Management") OR LIMIT-TO ( EXACTSRCTITLE, "Journal Of Business Logistics" ) )

${ }^{7}$ Based on AJG classifications: "Management \& organization science" = AJG ORG STUD + AJG ETHICS-CSR-MAN + AJG INNOV + AJG OR\&MANSCI, "Information systems science" = AJG INFO MAN and "Operations \& technology management" = AJG OPS\&TECH.

${ }^{8}$ In practice, this entailed an automated search for the words "Aken", "Simon", "Romme", "Holmström", "Peffers", "Gregor", "Hevner" and "March" in each article's list of references.

${ }^{9}$ A number of full texts of the excluded articles were randomly checked to verify the exclusion approach.
} 
$47 \%$ of the articles in the sample were published in Business Process Management Journal (BPMJ). Based on an initial full text evaluation of the 15 BPMJ articles, I decided to exclude them from the sample on the basis that they were clearly building on the IS DS tradition, and presenting IS artifacts. The footprint analysis was also corrected based on this decision.

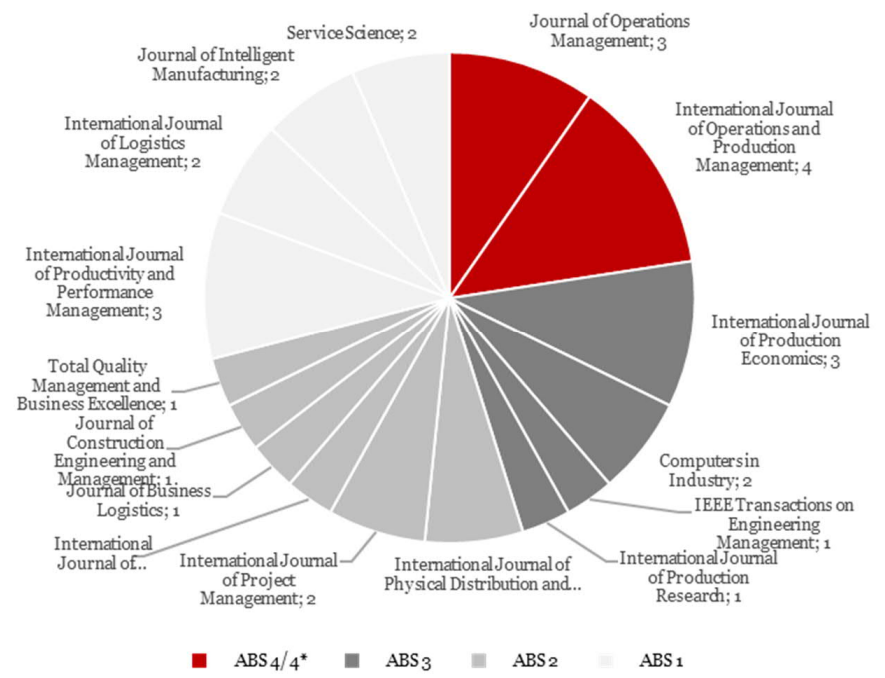

Figure 6 - Design science research outlets in OM (excluding BPMJ)

This left a sample of 26 articles, which were subjected to full text evaluation. Of these 26, a further 9 articles were excluded from the analysis, based on the full text evaluation. One criteria for exclusion was that they did not seem to contain a design (Ahlemann, El Arbi, Kaiser, \& Heck, 2013; Jonsson \& Holmström, 2016; Maniak \& Midler, 2014; van Aken et al., 2016). Another criteria was that I perceived them to build on the IS DS tradition (Ebner, Mueller, Urbach, Riempp, \& Krcmar, 2016; Hofmann \& Rutschmann, 2018; Jain, Shao, \& Shin, 2017) or DS in organization science (Maier, Moultrie, \& Clarkson, 2012). A final criteria of exclusion was that the article did not have a pragmatic objective, which led to ruling out designs which were consolidating prior research, seemingly intended for an academic audience (Kauremaa \& Tanskanen, 2016; Maniak \& Midler, 2014). This led to a final sample of 17 DS articles in OM.

The designs in these articles are related to various areas within $\mathrm{OM}$, with a clear emphasis on logistics (11 articles). Within logistics DS has predominantly been applied with the purpose of (aiding) introduction of new technology (Hinkka, Häkkinen, Holmström, \& Främling, 2015; Holmström, Främling, \& Ala-Risku, 2010; Kjellsdotter Ivert \& Jonsson, 2014; Moon \& Ngai, 2010). Further, DS in logistics has aimed at facilitating information sharing (Kaipia, Holmström, Småros, \& Rajala, 2017), identifying business models (Soinio, Tanskanen, \& Finne, 2012) and coping with (sustainability) risk (Busse, Schleper, Weilenmann, \& Wagner, 2017; Reinerth, Busse, \& Wagner, 2018). Also, in construction project logistics, DS (including article 3) has been used to introduce corporate-level Vendor-managed-Inventory (VMI) (Tanskanen, 
Holmström, Elfving, \& Talvitie, 2009; Tanskanen, Holmström, \& Öhman, 2015).

Other work concentrating on project management environments include the Human Resource Management (HRM) framework presented by Pournader et.al. (2015). Another distinguishable class of designs are designs related to performance measurement and management (Abaunza, Hameri, \& Niemi, 2018; Jääskeläinen \& Roitto, 2015; Öhman, Finne, \& Holmström, 2015). While Jääskeläinen \& Roitto (2015) present a generic design for evaluating performance management maturity in organizations, the other two articles (including article 1) present new context-bound methods for performance management, which are tested based on empirical operational data (Abaunza et al., 2018; Öhman et al., 2015). More recent DS contributions in OM venture into the contexts of healthcare (Groop et al., 2017) and education (Finne, 2018), combining OM knowledge (capacity management and service system design respectively) with domain knowledge in solving their respective problems.

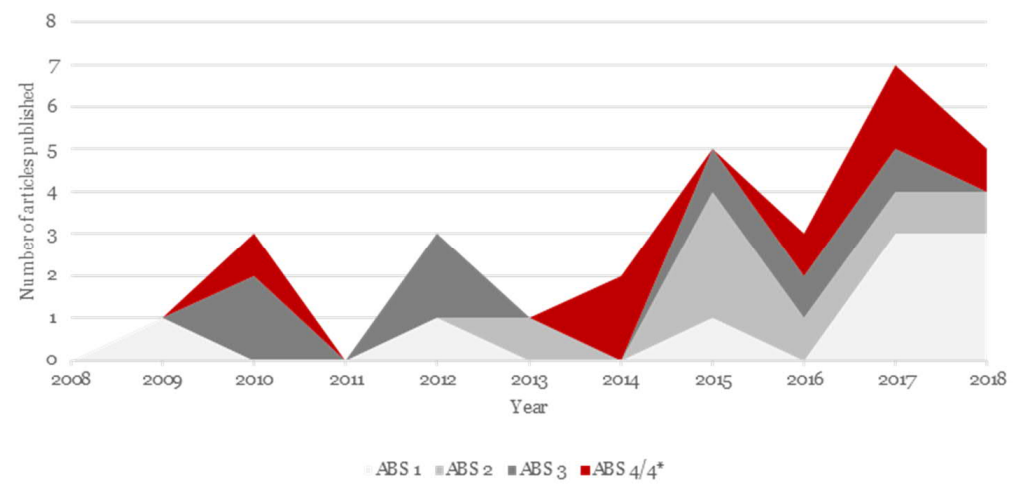

Figure 7 - Published Design Science articles in OM (excluding BPMJ, from 2008)

The actual designs put forth in these articles take a wide range of shapes and forms, including measures (Abaunza et al., 2018; Öhman et al., 2015), typologies (Hinkka et al., 2015; Soinio et al., 2012), models or frameworks (Jääskeläinen \& Roitto, 2015; Kjellsdotter Ivert \& Jonsson, 2014; Moon \& Ngai, 2010; Pournader et al., 2015; Reinerth et al., 2018), physical designs (Tanskanen et al., 2009, 2015), processes or approaches (Busse et al., 2017; Finne, 2018; Kaipia et al., 2017) and sets of propositions and principles (Groop et al., 2017; Meyer, Buijs, Szirbik, \& Wortmann, 2014). An interesting exception in this sense is the article of Holmström et.al. (2010) where a technology-enabled design - tracking - is put at center stage, and its use and potential in different contexts is elaborated based on empirical data. In summary, the different aspects of design discussed in the previous section were in some form present in all articles, and with all designs - however, in light of the heterogeneity of designs in the derived literature sample, deducing meaningful categories or characteristics of OM designs would seem premature at this point.

Based on the review, it was apparent that a majority of DS research in OM is problem-driven, with just four articles (out of 17) being identified as opportunity 
driven DS (Holmström et al., 2010; Kjellsdotter Ivert \& Jonsson, 2014; Öhman et al., 2015; Soinio et al., 2012). The distinction between problem and solution did however, not always, nor unambiguously reveal which came first. In the reviewed articles, DS was generally referred to as an approach, with only a handful of articles referring to it as a methodology. Further, many of the reviewed articles had significant duality in their methodology-sections, often arguing for their methodological choices based on inductive or abductive case study methodology literature, adding that the research employed a DS approach. This could arguably be a reflection of lacking methodological legitimacy, and/or field specific traditions. These considerations serve as a natural bridge to the next section of this dissertation, where I discuss research design and methodology. 


\section{Research design}

"Scientific theories are universal statements. Like all linguistic representations, they are systems of signs or symbols. Theories are nets cast to catch what we call 'the world'; to rationalize, to explain and to master it. We endeavor to make the mesh even finer and finer."

(Popper, 1980, p. 59)

As briefly touched upon in the introduction, there is an epistemological tension in the field of management (Ketokivi \& Choi, 2014; Martela, 2015) between positivism and realism, with the positivist view traditionally (seen as) enjoying greater scientific legitimacy (Scudder \& Hill, 1998). Whereas positivism is anchored in a realist ontology, where the world exists independent of the observer, its counterpart, interpretivism is anchored in a constructivist ontology, which asserts that reality is constructed by its observer. As scientists share a desire to understand (i.e. create knowledge about) the world, different epistemological views translate to different views on what knowledge is valid (Bryman \& Bell, 2011) - and consequently how this knowledge can and should be researched. A common distinction between the two views is that positivism deduces truth from statistically significant conclusions drawn from quantitative data, whereas interpretivism induces truth from congruent views emerging from qualitative data.

Design science (DS) can be based on the epistemological orientation of pragmatism (Romme, 2003), which to some extent overcomes ontological dichotomies through emphasizing the value of knowledge. That is, "design research develops knowledge in the service of action" (Romme, 2003, p. 562), with the contention that whether knowledge is in fact knowledge, is determined by how useful it is (Wicks \& Freeman, 1998). Through this, pragmatism imposes a prescriptive, normative mission on the creation of knowledge, guided by scientific ethics (Wicks \& Freeman, 1998), rather than ontological considerations. Pragmatism has been criticized for defining the value or usefulness of knowledge "only specifically and in context” (Easton, 2010, p. 119). Yet, I contend that in a pragmatist orientation, the scientific ethic defines usefulness, driving discoveries which are useful beyond the context of research - "helping people to better cope with the world" (Wicks \& Freeman, 1998, p. 129). The pragmatic positioning of DS has been discussed both as establishing the epistemological common ground 
"on which science and humanities can meet" (Romme, 2003, p. 560) as an "elegant" escape from the paradigm debate in management (Pandza \& Thorpe, 2010, p. 172).

Despite being described as perpendicular to the positivist versus interpretivist (anti-positivist in Wicks \& Freeman(1998)) divide, the methodological discussion on DS (Holmström et al., 2009; van Aken, 2004) has persistently sought to relate itself to the divide, especially in terms of ontology. An illustrative example of this can be found in van Aken (2004, p. 240), where he positions his view as; "I follow realism's contention that there exists a real (material) world, independent from observers and their knowledge". He then continues by stating that "we can develop knowledge of that real world through our senses, even though sensory experiences are concept-laden and are therefore no objective images of the external world“ (van Aken, 2004, p. 240). This arguably reflects a pragmatic epistemology based on a realist ontology (Martela, 2015), to which knowledge may be expressed as universal statements, but will always take the form of value-laden (Wicks \& Freeman, 1998) linguistic representations (Popper, 1980).

Critical realism shares many of the properties discussed here as those of pragmatism, yet there is a distinct difference which makes me adhere to the latter. Martela (2015) contends that pragmatism does not work "towards theories that better correspond to some underlying reality, but rather into theories that allow human beings to have more control over the outcomes of their lives". This distinguishes pragmatism from critical realism through positing that explanations of how and why the world works as it does are essentially complementary, and respectively, competing (Martela, 2015). The relative liberty offered by the two epistemological positions in terms of "acceptable" methods and evidence, warranted a fairly inductive research approach in the articles that comprise this dissertation. This meant that potential ways of attaining knowledge were evaluated in terms of what was perceived as useful (Wicks \& Freeman, 1998), which meant that both what evidence was gathered, and how it was gathered/analyzed evolved during the research process. The "eventual" data collection and analysis methods are summarized in Table 1 . In the following sub-sections, I will elaborate on research approaches, collected evidence and analysis methods, focusing on how methodological guidelines were reflected in my research, and what problems arose. I will return to parts of these methodological discussions in the Findings-section, when I discuss research design from the perspective of design maturity. 
Table 1 - Methodological approach, evidence and analysis in the research articles

\begin{tabular}{|c|c|c|c|c|c|}
\hline & Article 1 & Article 2 & Article 3 & \multicolumn{2}{|c|}{ Article 4} \\
\hline Design & $\begin{array}{l}\text { Adaptive Pre- } \\
\text { ventive } \\
\text { Maintenance }\end{array}$ & $\begin{array}{l}\text { Scheduling } \\
\text { front-log }\end{array}$ & On-site shop & \multicolumn{2}{|c|}{ Condition Based Maintenance } \\
\hline $\begin{array}{l}\text { Research } \\
\text { context }\end{array}$ & $\begin{array}{l}\text { - Maintenance } \\
\text { service (ma- } \\
\text { chinery) }\end{array}$ & $\begin{array}{l}\text { - In-house } \\
\text { Maintenance } \\
\text { (aviation) }\end{array}$ & $\begin{array}{l}\text { - Project com- } \\
\text { pany (con- } \\
\text { struction) }\end{array}$ & $\begin{array}{l}\text { - Maintenance } \\
\text { service (ma- } \\
\text { chinery) } \\
\text { - In-house } \\
\text { Maintenance } \\
\text { (aviation) }\end{array}$ & $\begin{array}{l}\text { - Maintenance } \\
\text { service (ma- } \\
\text { chinima, ma- } \\
\text { rine) } \\
\text { - In-house } \\
\text { Maintenance } \\
\text { (aviation, rail } \\
\text { logistics) } \\
\text { - Asset man- } \\
\text { agement (In- } \\
\text { frastructure) }\end{array}$ \\
\hline $\begin{array}{l}\text { Research } \\
\text { approach }\end{array}$ & $\begin{array}{l}\text { Single case } \\
\text { study (with } \\
\text { embedded unit } \\
\text { of analysis) }\end{array}$ & $\begin{array}{l}\text { Single case } \\
\text { study (with } \\
\text { embedded unit } \\
\text { of analysis) }\end{array}$ & $\begin{array}{l}\text { Single case } \\
\text { study (with } \\
\text { embedded unit } \\
\text { of analysis) }\end{array}$ & $\begin{array}{l}\text { Longitudinal } \\
\text { polar case } \\
\text { study }\end{array}$ & $\begin{array}{l}\text { Multiple case } \\
\text { study }\end{array}$ \\
\hline $\begin{array}{l}\text { Unit of } \\
\text { analysis }\end{array}$ & $\begin{array}{l}3 \text { pools of } \\
\text { equipment } \\
\text { served by the } \\
\text { company in } \\
\text { different coun- } \\
\text { tries }\end{array}$ & $\begin{array}{l}5 \text { fleets of air- } \\
\text { craft served by } \\
\text { the organiza- } \\
\text { tion }\end{array}$ & $\begin{array}{l}14 \text { stakehold- } \\
\text { ers interacting } \\
\text { with the design } \\
\text { (8 construction } \\
\text { projects, } 4 \text { sup- } \\
\text { pliers and } 2 \\
\text { developers) }\end{array}$ & $\begin{array}{l}2 \text { companies } \\
\text { implementing } \\
\text { the design }\end{array}$ & $\begin{array}{l}5 \text { companies } \\
\text { who had im- } \\
\text { plemented or } \\
\text { were imple- } \\
\text { menting the } \\
\text { design }\end{array}$ \\
\hline $\begin{array}{l}\text { Collected } \\
\text { evidence }\end{array}$ & $\begin{array}{l}\text { - } 3 \text { semi-struc- } \\
\text { tured inter- } \\
\text { views }\left(1,5^{-}\right. \\
2 \mathrm{~h}) \\
\text { - } 3 \text { workshops } \\
(1,5-3,5 \mathrm{~h}) \\
\text { - Field obser- } \\
\text { vation (3,5h) } \\
\text { - Operational } \\
\text { database ex- } \\
\text { tracts } \\
\text { - Operational } \\
\text { documenta- } \\
\text { tion }\end{array}$ & $\begin{array}{l}\text { - } 5 \text { semi-struc- } \\
\text { tured inter- } \\
\text { views (1-2h) } \\
\text { - Operational } \\
\text { database ex- } \\
\text { tracts } \\
\text { - Operational } \\
\text { documenta- } \\
\text { tion }\end{array}$ & $\begin{array}{l}\text { - } 55 \text { semi- } \\
\text { structured } \\
\text { interviews } \\
(0,25-1 \mathrm{~h}) \\
\text { - Operational } \\
\text { database ex- } \\
\text { tracts } \\
\text { - Field obser- } \\
\text { vation } \\
\text { - Operational } \\
\text { documenta- } \\
\text { tion }\end{array}$ & $\begin{array}{l}\text { - } 33 \text { semi- } \\
\text { structured } \\
\text { interviews } \\
(0,5-3,5 \mathrm{~h}) \\
\text { - Field obser- } \\
\text { vation } \\
(36,5 \mathrm{~h}) \\
\text { - Operational } \\
\text { database ex- } \\
\text { tracts } \\
\text { - Operational } \\
\text { documenta- } \\
\text { tion }\end{array}$ & $\begin{array}{l}\text { - } 7 \text { semi-struc- } \\
\text { tured inter- } \\
\text { views (a total } \\
\text { of } 12 \text { inform- } \\
\text { ants, lasting } \\
1,5^{-2}-5 \text { h) }\end{array}$ \\
\hline $\begin{array}{l}\text { Main } \\
\text { analysis } \\
\text { method }\end{array}$ & $\begin{array}{l}\text { - Quantitative } \\
\text { analysis (Ex- } \\
\text { cel) } \\
\text { - Driven by ex- } \\
\text { ploration }\end{array}$ & $\begin{array}{l}\text { - Simulation } \\
\text { (Python) } \\
\text { - Driven by hy- } \\
\text { pothesis }\end{array}$ & $\begin{array}{l}\text { - Qualitative } \\
\text { content anal- } \\
\text { ysis } \\
\text { - Driven by ex- } \\
\text { ploration }\end{array}$ & $\begin{array}{l}\text { - Qualitative } \\
\text { content anal- } \\
\text { ysis } \\
\text { - Driven by ex- } \\
\text { ploration }\end{array}$ & $\begin{array}{l}\text { - Qualitative } \\
\text { content anal- } \\
\text { ysis } \\
\text { - Driven by hy- } \\
\text { pothesis/ ex- } \\
\text { ploration }\end{array}$ \\
\hline
\end{tabular}

\subsection{Case studies as context-bound inquiries}

In this section, I discuss methodological aspects of the different case study approaches used in the appended articles, preceded by a brief general introduction to the methodology. Case studies have gained significant traction in organization and management research in the last three decades (Ketokivi \& Choi, 2014), accompanied by a lively methodological discussion (cf. Barratt, Choi, \& Li, 2011; 
Eisenhardt, 1989; McCutcheon \& Meredith, 1993; Siggelkow, 2007; Stuart, McCutcheon, Handfield, McLachlin, \& Samson, 2002; Voss, Tsikriktsis, \& Frohlich, 2002). However, despite established how-to handbooks (e.g. Yin, 2009), case-based research still displays significant methodological diversity (Ketokivi \& Choi, 2014). Yin (2009, p. 18) defines case study as an empirical inquiry that "investigates a contemporary phenomenon in depth and within its real-life context, especially when the boundaries between phenomenon and context are not clearly evident”. The flexibility conveyed by this definition, has arguably led to the predominance of inductive case studies in $\mathrm{OM}$, along with growing concerns for research rigor (Barratt et al., 2011).

Acknowledging these concerns, Ketokivi \& Choi (2014) argue that rigor should not be sought in terms of a normative research process (which would negate inherent strength of the approach), but rather through process transparency. With "acceptable" scientific process (and evidence) being a matter of inquiryspecific justification, the essence of case studies thus boil down to being "situationally grounded", while seeking "a sense of generality” (Ketokivi \& Choi, 2014, p. 234). As designs are per definition situationally grounded, and the objective of design science is seeking a sense of generality (Holmström et al., 2009), it is perhaps not surprising that design studies are often discussed in terms of cases - sometimes even case studies (without implying that one label would exclude the other). In DS methodological discussions, references to case study research are more subtle, with the exception of van Aken (2004, 2005) arguing for crosscase analysis methods in research on design transferability. Holmström et.al. (2009) also acknowledge similarities between their substantive theory-building phase, and inductive multiple case study research, with the distinction that in DS the research design can be quasi-experimental, with the researcher participating in the introduction of the design to new contexts.

\subsubsection{Applied case study approaches}

In my research, I have used the term case study mainly in the meaning of situationally grounded research, relatively free from normative prescriptions related to research process or types of evidence - mainly guided by an ethos of pragmatism in this sense. During the course of the dissertation research, I have conducted research arguably falling under different categories of case research. In this section, I will briefly elaborate on the different research designs, relying on case rhetoric, with an emphasis on the relationship between chosen method and "situational groundedness" of the design.

\section{Single case studies}

From a theoretical (deductive) point of view, single case studies are justifiable when the case reflects theory to the extent that the single case can confirm, challenge or extend the theory (Yin, 2009). From an empirical (inductive or abductive) point of view, single case studies are justifiable when the case represents an opportunity to study something unique or previously inaccessible (Yin, 2009). Whether theoretically or empirically motivated, the scientific impact of the single case is based on it serving as a powerful example (Siggelkow, 2007) 
of "interaction between a phenomenon and its context" (Dubois \& Gadde, 2002a, p. 554).

Articles 1, 2 and 3 all rely on single case studies, necessitated by the relatively low maturity of the design. Reflected against Yin (2009), the studies are motivated from an empirical point of view by the uniqueness of the design (it does not exist elsewhere) and its previous inaccessibility (it did not exist prior to the research). The case, as (implicitly or explicitly) defined in the articles, is the economic organization within its industry context - reflecting a typical delimitation in (operations) management research.

Within this case definition, the objective was to gain a rich understanding of the operational context of and within the firm (Barratt et al., 2011), in order to understand and anticipate design behavior. Despite possible ambiguity in the interface between design and (firm) context (which was tangible especially in the research leading to article 3), the unit of analysis in design science is always the design. In all research articles, heterogeneity in firm operations was reflected by heterogeneous (operational) design structure and/or behavior, which justifies framing these design studies as embedded single-case studies.

\section{Embedded case studies}

Yin (2009) argues that the advantage of an embedded case research design is that it prevents drifting of the research (which is one of the common criticism of case studies), through focusing the case study inquiry. On the other hand, embedded case studies run into problems if the research "focuses only on the subunit level and fails to return to the larger unit of analysis" (Yin, 2009, p. 52). The latter argument is essentially saying that if findings and conclusions are solely related to the embedded unit of analysis, the distinction between case and context would seem arbitrary - leading to a situation where "the original phenomenon of interest has become the context and not the target of study" (Yin, 2009, p. 52).

In operations management research this question is peculiar in the sense that operations is embedded in the economic organization (firm), which in turn is embedded in industry (market), both of which tend to have implications for operations management. While both provide context to the design, they differ in the important sense that from an experimental point-of-view the former is easier to manipulate than the latter. In other words, a firm may accommodate a change required by a design, but an industry cannot be expected to do so.

In the research leading to article 1, the developed design was tested on three distinct equipment populations, which were further analyzed on sub-component (9) level, with different usage- (3) and environmental (3) characteristics, implying that the design was tested on 243 different populations within the setting provided by the case company. In the research leading to article 2 , the developed design was tested on an operational level, but evaluated for five different fleets of aircraft with different operational characteristics.

Finally, at the time of the research leading to article 3, the design was employed in 26 ongoing construction projects, of which 8 were included in the 
study, further, as the perception of the design (Orlikowski \& Gash, 1994) was focal in the research, also four different roles related to, or perspectives on the design were studied. While the relative independence of the projects in article 3 could have warranted a multiple case study label for the research, the (generic) design was introduced on a company level. Further, the studied roles could not all be explicitly related to projects. This being said, article 4 arguably employed a multiple case study design.

\section{Multiple case studies}

Single case studies can be, and are, often criticized on the grounds that generalizable statements (contributions to formal theory) cannot be drawn from single contexts. Multiple case studies face milder criticism in this respect, which adds to their appeal (Yin, 2009). Since the seminal article by Eisenhardt (1989), multiple case studies have gained traction in management (and by extension operations management), as a viable research approach for theory building.

In later work, Eisenhardt \& Grabner (2007, p. 27) contrast multiple case versus single case studies, positing that multiple case research "typically yields more robust, generalizable, and testable theory. However, as pointed out by Yin (2009), apart from being resource consuming, multiple case studies cannot readily rely on the same justifications as single case studies. Further, in terms of reporting research, let alone conveying the rich context, multiple case research presents a challenge (Barratt et al., 2011).

A key issue in multiple case research is sampling, with authors stressing that sampling should be done on a theoretical basis (Eisenhardt, 1989; Yin, 2009), rather than assuming that "cases should be representative of some population" (Eisenhardt \& Graebner, 2007, p. 27). In contrast to this Eisenhardt (1989, p. 545) states that "there is no ideal number of case", but continues by suggesting that 4-10 cases "usually works well" - which has, given the impact of the article, perhaps drawn reviewers attentions away from the "theoreticalness" of sampling.

Voss et.al (2002) advocate a less is more approach in this sense, as they note that "the fewer the case studies, the greater the opportunity for depth of observation". Indeed, an important basis for theoretical sampling may involve finding just two cases - which are polar opposites (Eisenhardt, 1989; Eisenhardt \& Graebner, 2007), termed a "two-tail" research design by Yin (2009, p. 59). The research leading to article 4 employed a multiple case design, with two initial longitudinal case studies (cf. Leonard-Barton, 1990) in very different (arguably polar) contexts. These cases in turn enabled theoretical sampling for the eventual multiple case study, in which the original cases were also included.

\subsubsection{Applied approaches for studying the long-term}

One of the strengths of case studies, which distinguishes them from historical studies, is that they study contemporary phenomena (Yin, 2009). So how do you study phenomena that "happen over time"? This question is relevant in OM DS research especially as short-term success does not guarantee long-term success 
of OM interventions (Done, Voss, \& Rytter, 2011). During the course of the dissertation research, I have used both longitudinal case study and empirically grounded simulation, in order to understand how the perception of a design evolves, and how the outcome of a design is materialized over time.

\section{Longitudinal case study}

Determining the relationship between cause and effect based on retrospective accounts of events has been associated with several potential problems (Voss et al., 2002). Although informants are relatively good at remembering key events, this is contingent on the realizing the importance of the event at the time of occurrence (Leonard-Barton, 1990). Further, Voss et.al. (2002) highlight the risk of post-rationalization, where information gained after an event affects the interpretation of the event. These risks can be mitigated though conducting a longitudinal case study, where the same case is revisited at two or more different points in time (Yin, 2009). Both polar cases, which were part of the research leading to article 4, were longitudinal - providing valuable insight into how the perception of the design evolved over time, consequently affecting design choices.

\section{Empirically grounded simulation}

"Because organizations are complex systems and many of their characteristics and behaviors are often inaccessible to researchers, especially over time, simulation can be a particularly useful research tool for management theorists" (Harrison, Carroll, \& Carley, 2007, p. 1243). Also Yin (2009) discusses "logic models" for analyzing complex chains of events characterized by repeated cause-effect-cause-effect patterns, which is arguably close to simulation modelling.

Successful simulation projects are driven by a good problem (and solution) formulation (Law, 2003). Further, empirical grounding of a model provides a foundation for evaluating problem relevance and solution impact. Both case study- and action research methods provide rich information, which is crucial in constructing a simulation model and its logic (Forrester, 1992). Consequently, Romme (2003, p. 569) notes that simulation modelling holds potential for DS, as it enables design scientists to "build and test models describing the current and desired (states of the) system, which helps them to move outside the mental boundaries of the current situation".

In the research leading to article 2, a simulation model was built in order to study the long-term effects of introducing the design into the studied context. The outcome of deliberate introduction of over-maintenance was known to be probabilistic - which called for an a priori evaluation of long-term effects of design implementation. For this purpose, over 2000 years of aircraft maintenance operations, with different design parameters were simulated, concluding that implementing the design would have a significant positive (average) effect. 


\subsection{Collecting evidence on designs and context}

In this section, I present methodological considerations of the main types of evidence that comprise this thesis, preceded by the three principles which guided the planning and collection process: saturation, snowballing ${ }^{10}$ and triangulation (Eisenhardt, 1989; Yin, 2009). The first principle denotes open-ended sampling in the sense, that additional evidence is collected (concurrently with analysis), until the findings begin to repeat themselves, i.e. saturate. The second principle denotes that evidence is allowed to spawn new relevant evidence (i.e. interviewees are asked to suggest who should be interviewed on the given subject). The third principle denotes the use of multiple sources of evidence (on the same object of research), which can produce valuable insight, especially when contrasting subjective evidence (such as interviews) against more objective evidence (such as operational database extracts). Based on these principles, five main types of evidence were collected for the articles that comprise this dissertation - semi-structured interviews, workshops, field observations, operational database extracts and operational documentation - these are briefly presented and discussed next.

\section{Semi-structured interviews}

To the extent that case studies are perceived as a qualitative research approach, interviews are arguably the core evidence, which allows to "obtain both retrospective and real-time accounts by those people experiencing the phenomenon [or design] of theoretical interest" (Gioia, Corley, \& Hamilton, 2013, p. 19). By labelling my interviews as semi-structured, I share Yin's (2009, p. 106) view in that interviews are "guided conversations rather than structured queries". In practice, this meant that although the interviews were conducted with pre-prepared interview guides within an agreed time-slot, the questions were designed so that, rather than probing facts, they invited the interviewee to share and discuss his/her viewpoint on the given subject ${ }^{11}$.

These viewpoints would then typically lead to more or less ad-hoc follow-up questions probing seemingly interesting aspects of the given answer. While this approach arguably led to rich and detailed evidence, it required undivided attention from the interviewer, leaving little room for taking detailed notes. In order for the interviewer to be able to focus on the answers and developing the relevant follow-up questions, the vast majority of interviews were recorded, with a few exceptions where the interviewee(s) did not wish to be recorded ${ }^{12}$. The recorded interviews were then transcribed for analysis, to large part by an external service provider.

In all research projects, the interviews were designed as to probe the interviewees' view of the business context, and in articles 3 and 4, a key part of the

\footnotetext{
${ }^{10}$ Briefly touched upon by both Eisenhardt (1989) and Yin (2009) under different labels, for further methodological insight on snowballing, refer to Biernacki \& Waldorf (1981) and Noy (2008).

${ }^{11}$ Avoiding formulation such as "how does A work?" and "why does A cause B?", instead using "how do you see that A works - or does it work?" and "do you think A causes B, and if so, why do you think it does?".

${ }^{12}$ Two instances. In these situations, rough notes were taken during the interview, to be complemented and elaborated as soon as possible after the interview.
} 
interview was aimed at probing the interviewee's view of the design in question. For article 1, the interviews were further intended to elaborate on the foundations of the proposed solution, i.e. to understand what information the organization could leverage (and how it could do so) to solve a problem. For article 2, the interviews were mainly conducted in order to understand how maintenance scheduling was currently done in the company, with an emphasis on uncovering undocumented heuristics. In article 3 , the focus was on probing the perceptions of the interviewees, not only of the design, but also of other stakeholders, and their incentives, roles and responsibilities with respect to the design. Finally, in the in-depth cases for article 4, the focus of the interviews was more broadly on maintenance decision-making, in order to create a rich and detailed understanding of the specific context, which then guided the design of a focused (interview-based) inquiry in the multiple-case study. In the research leading to articles 3 \& 4 interviews were partially conducted by two investigators.

\section{Workshops}

Falling somewhere between interviews and (participant-) observations, researcher-facilitated workshops have been used as a source of evidence in some OM research (cf. Erkoyuncu et al., 2013). Perhaps due to the relative scarcity of research using workshops as evidence, there has been no explicit methodological discussion or elaboration on the subject. On the other hand a researcherfacilitated workshop could arguably be seen as a special case of a facilitated (cf. Cooren et al., 2006) focus groups (cf. Smithson, 2000), where the researcher and participants together explore a topic (or a problem/solution) as framed by the researcher.

Researcher-facilitated workshops were used for two distinct purposes in this dissertation. In the research leading to article 1, the conducted workshops produced vital evidence in understanding and exploring the (design-) opportunity presented by installed-base information. On one hand, this entailed an interactive exploration of the case-context, in search for potential opportunities; on the other hand, it entailed the construction of a shared perception of the solution. In the research leading to article 4, the workshop was used mainly for the purpose of validation, where the researcher's framing was presented to, and discussed by the case representatives (interviewees) from the different cases (contexts). In this case, the workshop also served as a forum for knowledge transfer between contexts, as participants engaged in cross-context discussions on design specifics.

\section{Field observations}

Yin (2009) distinguishes between direct observation and participant-observation. In the former, the researcher maintains a passive role with respect to the object of study, whereas in the latter the researcher assumes a role in the case setting, interacting with the object of study - a compelling source of evidence for action-oriented design scientists (cf. Sein et al., 2011). The observations conducted for this dissertation were in a sense somewhere in between, as I did not 
actively participate in the activities that I observed, but did actively seek to engage in informal discussions with the technicians and specialists performing the activities.

In the research leading to article 1, I tagged along a service technician in order to get a feel for the daily work of a field technician in the case context. In the research leading to article 3 , in connection to the construction-site interviews, I requested access to the design on site, which provided valuable complementary evidence in terms of accessibility, housekeeping and operation of the small-item inventory. The most extensive set of observations were conducted in one of the polar cases leading to article 4, where I tagged along maintenance crews working on the apron and observed decision-making in the maintenance controlcenter. All of the observations were prepared through constructing detailed observation protocols, where the events and circumstances of interest were identified. For articles 1 and 4, the observation evidence was recorded in the field during the observation, and written up (typically within 24 hours) after the observation. For article 3, the observation evidence was recorded as soon as possible after the observation (in practice this was always done the same day as the observation).

\section{Operational database extracts}

Being a close equivalent to archival records (Yin, 2009, p. 102), operational database extracts could be expected to be stable, unobtrusive, precise and usually quantitative. As for being precise, Yin (2009, p. 106) notes that "an investigator must be careful to ascertain the conditions under which [the archival record] was produced as well as its accuracy" and continues by noting that the records were not collected for the purpose of the case study, which needs to be appreciated when building conclusions on them. In the operational database extracts analyzed for this dissertation, accuracy was indeed an issue, requiring significant "detective work" and interaction with case representatives, as to figure out inconsistencies and seemingly strange deviations observed in the data, mainly related to manually collected data (Rämänen, Mahlamäki, Borgman, \& Nieminen, 2013).

Operational database extracts were in some form or role used in all dissertation articles, being the main source of evidence for articles $1 \& 2$. The contribution of article 1 is built on an analysis of service records (in the order of $>100 \mathrm{k}$ service events), which were recorded by field technicians during service delivery. Additionally the analysis required combining other operational and technical data with the service records. In the research leading to article 2, operational database extracts were used to initialize the simulation model, in creating the traffic program, available aircraft and their maintenance programs. Further, probability distributions for different events in the simulation were derived based on service records, which were also used in model validation. In article 3 operational database extracts provided (complementary) evidence of inventory related behavior, while in article 4 they provided evidence on service responsiveness and failure predictability. 


\section{Operational documentation}

Yin (2009, p. 103) argues that "for case studies, the most important use of documents is to corroborate and augment evidence from other sources". This largely corresponds to the role of operational documentation evidence in the work comprising this dissertation. For all research projects, some form of documentation pertaining to operational processes, roles or structures were obtained. This documentation typically provided (potentially very detailed) normative accounts of how things should be done, which provided a base to reflect upon when collecting other evidence. In retrospect it stands clear that in all cases, the documentation would have (as such) provided an insufficient (blackand-white) account of what actually happened in the field.

\subsection{Analyzing evidence on designs and context}

In this section, I elaborate analysis of evidence as part of the abductive research process in the articles that comprise this thesis. The role of theory in drawing conclusions from evidence has been widely debated, with inductive and deductive reasoning occupying different ends of the spectrum, and abductive reasoning (Dubois \& Gadde, 2002a; Mantere \& Ketokivi, 2013) falling somewhere in between. Inductive reasoning entails that theory is the product of the analysis of the evidence, often embodied in researchers stating that they approached the analysis "tabula rasa" (B. G. Glaser \& Strauss, 1999), and that the conclusions thus emerged from the evidence. Deductive reasoning derives a hypothesis from extant theory, and the (often large-sample statistical) analysis is specifically designed to prove or disprove the hypothesis.

These two extremes can be criticized, from the perspective of knowledge creation. The former on the premise that the researcher's (presumably theory-informed) mental models are bound to affect how the researcher make sense of phenomena, implying that tabula rasa is de facto unattainable, and that any theory "emerging" form data is a replication of these (presumably theory-informed) mental models. The later on the premise that operationalizing theoretical concepts implies bending reality to fit theory, at worst leading to detachment from reality, causing circular reasoning and loss of prescriptive relevance ${ }^{13}$. An abductive reasoning approach resolves this dilemma through allowing and advocating iterative analysis, which oscillates between theory and evidence, in a parallel search of possible interpretations ${ }^{14}$ (cf. Mantere \& Ketokivi, 2013), sometimes through analogies (Ketokivi, Mantere, \& Cornelissen, 2017).

While articles $1 \& 2$ mainly rely on quantitative analysis, and articles $3 \& 4$ on qualitative analysis, the analysis process in all articles were arguably abductive. For article 1 the analysis was initiated under the assumption that it would be interesting to see how the failure rate developed after a service event. Once the analysis had progressed to the stage, showing a relatively flat failure rate, the

\footnotetext{
${ }^{13}$ With knowledge contributions that boil down to "doing things right leads to good performance".

${ }^{14}$ In a pragmatic view, the word "possible" would be substituted with "valuable", in the sense that any explanation that adds unique understanding, irrespective of its explanatory power relative to other explanations, is per definition valuable.
} 
realization came that based on reliability theory, the service interval could then be prolonged (at least to some extent) without affecting the failure rate. Once the data was re-analyzed through the frame provided by the theory, the next realization came, where the distinction between common- and special-cause failures in reliability theory were directly relatable to statistical process control (SPC). This realization gave rise to the final measurement and control approach described in article 1.

The research for article 2 was guided by the hypothesis that deliberate introduction of over-maintenance would be a (to some extent) cost-efficient way to increase flexibility in the aircraft maintenance operations. This hypothesis emerged from a suspicion that the empirical context, and by extension research done in the context of aviation, was biased against over-maintaining as it was perceived inherently costly. The analysis confirmed the hypothesis, and gave rise to the (abductive) theoretical realization that over-maintenance could be seen as a form of (service) inventory, pointing towards potentially interesting avenues for further research.

Articles 3 \& 4 were both mainly based on analysis of qualitative evidence, in the form of transcribed interviews. As the research leading to article 3 explicitly set out to explore the technological frames (Orlikowski \& Gash, 1994) of different design stakeholders, it did in a sense rely on a theoretical basis. The point was however not to prove that perception of the design affects interaction with it, but rather to understanding how it affects interaction. As the analysis progressed, different perspectives to this interaction arose (set-up process, communication, integration, collaboration, congruence), arguably associable with different theoretical traditions ${ }^{15}$ (cf. Ohno, 1988; Orlikowski \& Gash, 1994; Schonberger, 2008; Wu \& Choi, 2005; Wu, Choi, \& Rungtusanatham, 2010). In the end, the contribution was argued as a novel design theory of adoption of logistics innovation.

In article 4 the process was similar in the sense that early stage data analysis was initiated with an information processing perspective (Galbraith, 1974), focusing on who made decisions, when, where and based on what information which awoke the interest in maintenance decisions based on equipment condition. About the same time the contingency perspective came in, which led to a search of contextual cues in the evidence. Finally, in a late stage of the analysis, prior conceptualizations of CBM were brought in to the analysis. The interplay between theory and analysis is especially notable here, in the sense that I argue ${ }^{16}$ that if CBM "theory" would have been introduced at an earlier stage, it could have led to a limited view (Eisenhardt, 1989) of the design, in turn leading to myself overlooking some of the contextual nuances of implementations.

For both articles ( $3 \& 4$ ) the interviews were analyzed through tagging statements in the interview transcripts that were deemed to reflect some part of the empirical/theoretical framing. The extracted tags were then grouped in order to

\footnotetext{
${ }^{15}$ Perhaps not surprisingly, the different perspectives are reflected in prior work of the researchers involved.

${ }^{16}$ Minding possible biases caused by the retrospective basis for this claim.
} 
form larger categories or concepts emerging from the data, which is a common approach in deriving insight from qualitative evidence (cf. Gioia et al., 2013; Miles \& Huberman, 1994). In article 3 , in order to avoid the introduction of single investigator bias, the grouping of large categories were conducted as a collaborative exercise between two researchers. Otherwise, possible biases were explored when discussing the results of the analysis (among co-authors and coinvestigators), in both analyses for articles 3 \& 4 .

During analysis, the trail of evidence was maintained (all the way to the recorded interviews) in order to enable retrospective re-categorization and doublechecking in case of ambiguous tags. Further, the case study evidence was collected in case study databases, along with the instruments used to obtain it in an attempt to conform to guidelines (cf. Yin, 2009, p. 45) on securing the reliability of findings. The validity of the conducted research (cf. Yin, 2009, pp. 4044) is based on extensive data triangulation (section 3.2), partial investigator triangulation both in data collection (section 3.2) and analysis (including reviews of results by key informants), and theoretical triangulation through it being inherent to abductive analysis. 



\section{Findings}

In this section, I present the findings of the appended research articles, with respect to the research questions. I begin (section 4.1) by revisiting the view of design maturity derived from previous research in section 2.1, reflecting it against the empirical work that comprises this thesis. The main finding of reflection is that the early stages of design maturity are not necessarily as objective and analytic as Simon (1996) argues. As I was the designer in the research leading to articles $1 \& 2$, the findings here also seek to convey an introspective account of how the early designs have matured. In section 4.2 I present the knowledge contributions of the articles that comprise this dissertation, and relate them to design maturity. The main finding arising in this section is that based on a pragmatic view of knowledge, all design stages have the potential to create new (valuable) knowledge - however, the validity of that knowledge is dependent on the nature of the design. The main finding here is that designs with significant emergent properties need to be more mature in order to produce valid knowledge. Finally, in section 4.3 , the findings presented in sections 4.1 and 4.2 are reflected against prior DS research in OM.

\subsection{How designs mature}

Building on the conceptualization of design maturity derived from prior research (section 2.1.4), I develop a complementary view on maturity, based on my empirical research. The main difference to the conceptualization derived from the work of Simon (1996), is that search and build are not treated as distinct phases. The reason for this is that, in the empirical research, they are intertwined to the extent that making a distinction between the two does not seem meaningful. This is not to say that this kind of activities did not take place, but rather that a process-like search for alternatives, followed by the evaluation of their utility and ultimate selection of the best alternative, as discussed by Simon (1996), could not be discerned. The challenge of distinguishing between search, evaluation and selection in the research leading to articles $1 \& 2$ is likely to be at least partly rooted in the immaterial nature of the designs. For the most part however, the challenge reflects the inherent messiness (cf. Sarasvathy, 2003) of pre-implementation design. This leads me to the conclusion that a conceptualization of design maturity, at least from the perspective of knowledge creation, should be viewed as transitions rather than activities. Further, the pragmatic 
knowledge-interest of DS focuses on what ought to be becoming what is in a given context - making design implementation a pivotal point in design maturity.

An implementation-centric view of design maturity, leads to a conceptualization where search and build are design-activities, which happen pre-implementation. Pre-implementation is followed by implementation (in the original context), during which testing (and re-design) are the prime design activities. Although termed transfer, the design-activity of the next stage is better described as adaptation, as the design is re-implemented in a non-original context, typically, at least in the case of OM, by a secondary designer. The final design activity, generalization, is where what ought to be is deduced from what is, denoting a de-facto de-implementation of the design. Pre-implementation, implementation, re-implementation and de-implementation provide the structure for the findings on design maturity, below.

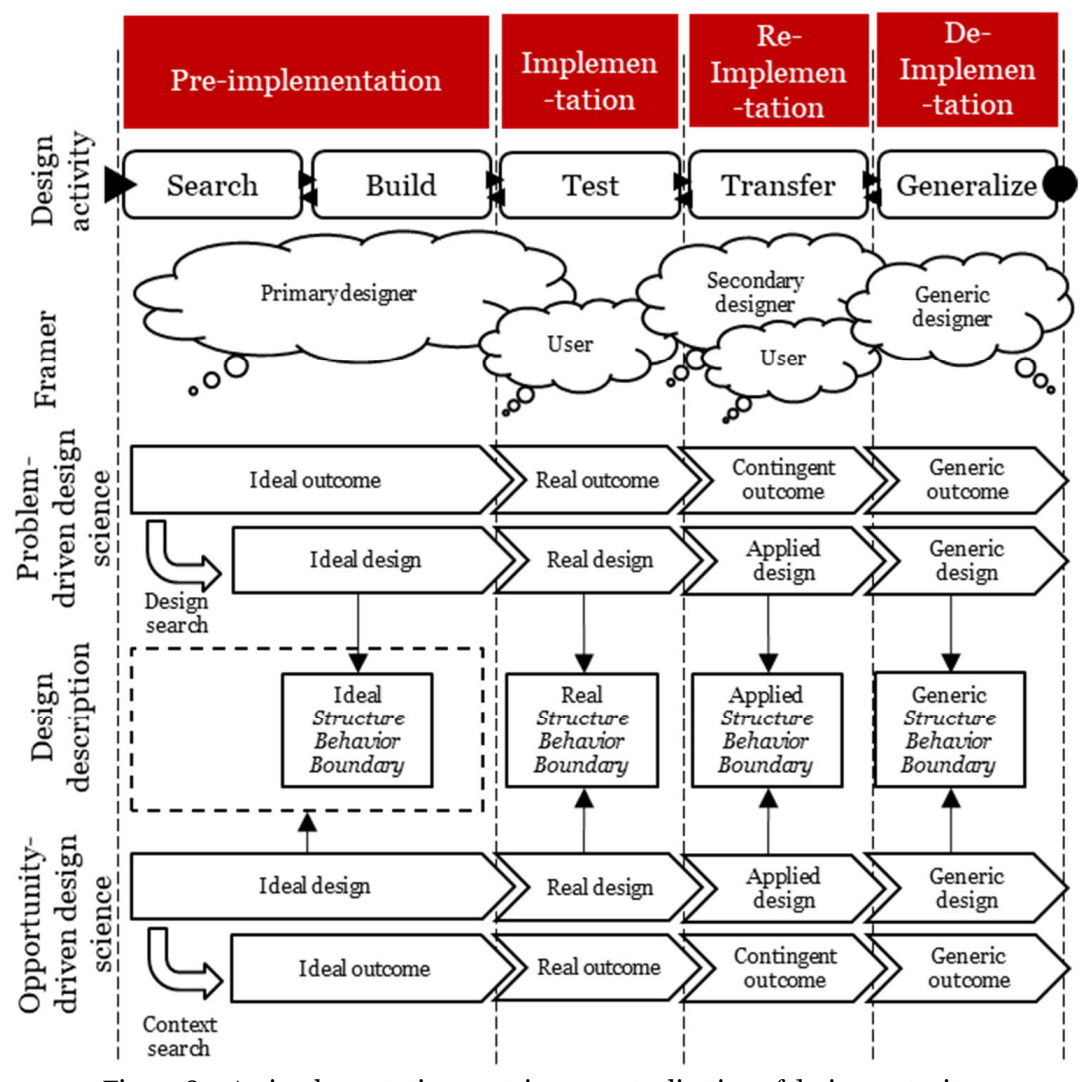

Figure 8 - An implementation-centric conceptualization of design maturity

\subsubsection{Pre-implementation}

In pre-implementation, the designer is preoccupied with search and build activities, which shape the design in terms of structure, behavior and boundary. Depending on whether the design process is problem or opportunity-driven, the search focuses on solution or context, respectively. Through framing and re- 
framing, the designer explores viable solutions or contexts, gradually resulting in a conceptualization of the design. This process of conceptualization is one of discovery, where the designer imposes meaning and attributes to the design. In both articles $1 \& 2$, this process of conceptualization was central in knowledge creation, with one framing providing the foundation for the consequent reframing. The recounts of the framing-process in the articles, below, also illustrate how designs mature during pre-implementation.

The research reported in article 1 was opportunity driven, starting from the question of how installed base information (IBI) (Ala-Risku, 2009) could be leveraged in service operations. The context search was in this case a search among activities within service operations, which gradually, driven by exploration of the available IBI, focused on service scheduling. A key insight emerged through the conceptualization of the service event as "making the equipment younger", which allowed for the implications of the bathtub-curve (R. E. Glaser, 1980; Klutke, Kiessler, \& Wortman, 2003), from reliability theory, to be applied in service scheduling. Further, with random failures being part of the bathtubcurve conceptualization, it paved the way for the next insight, that SPC could provide the foundation for a learning scheduling process.

While the research reported in article 2 was problem-driven, the framing / reframing process was similar. The research for this article started from an existing problem with an existing solution, i.e. the problem of workload fluctuation in aircraft line-maintenance, to which the existing solution was resource flexibility. In this research, the solution search was latent in the sense that the designer, me, was aware of the problem (due to previous research in the context), but had not focused on solving it, before deliberate introduction of over-maintenance appeared as a potential complementary solution ${ }^{17}$ to resource flexibility. The design was then conceptualized as an introduction of "buffer workload" in what was (at the time) called a scheduling buffer. The use of the word buffer, led to a perceived connection between the maturing design and coping with demand fluctuation in product supply-chains, which ultimately led to a tentative reframing of the scheduling buffer as an inventory of time. Further, as the scheduling buffer was seen as an inverse backlog (i.e. work is carried out before demand is imminent as opposed to after) the buffer was relabeled as a "frontlog". This is summarized in the following finding on how designs mature in pre-implementation:

\section{Pre-implemented designs mature through a process of framing and re- framing by the designer}

The maturing designs in articles $1 \& 2$ were not implemented during respective research projects. Both designs were immaterial (cf. Tanskanen et al., 2009), and neither of them led to any change in real systems ${ }^{18}$ (at that time). So what is a pre-implementation design? I would describe my designs as testable (ideal) representations of my ideas. These representations were built, refining the idea

\footnotetext{
${ }^{17}$ Arguably blurring the distinction between problem- and opportunity-driven research.

${ }^{18}$ There were however, indications of my designs affecting the thinking of the case company personnel involved in the research projects.
} 
in the process, resulting in a complex spreadsheet (article 1) and a simulation model (article 2). While being built, these representations were also (continuously) calibrated and tested with real data from the intended contexts. Hence, the design product of pre-implementation is an empirically grounded ideal design (described through ideal structure, -behavior and -borders), of which a testable representation can be built, producing an ideal outcome.

Examples of how the design matured during building of the design representation follows. In article 1, when building the SPC chart of the service outcome, there was a need to define control- and warning-limits for the chart. In previous applications of SPC, these limits are fixed, defined by the normal variation of a continuous time process. However, as the design entailed measuring variation in a relative time process (with process instances of different duration), it became apparent that the limits needed to diverge, rather than being fixed. In article 2, the design was conceptually framed as a buffer of planned work that could be postponed if needed. As the simulation model was built, however, it became apparent that the framing did not answer how such a buffer should be measured, or controlled, which would undoubtedly be an issue of interest to operations managers. This is summarized in the following finding on how designs mature in pre-implementation:

Pre-implemented designs mature in the process of being built, as context exposure surfaces practical problems, which need to be solved

While the empirical grounding of ideal designs should reduce the risk for circular reasoning, the ideal nature of the design invites the following question: to what extent can knowledge be extracted from designs that are not real? In research articles $1 \& 2$, I build my contributions based on a reasonable assumption of limited design emergence, which translates to the design outcome being independent of the user's perception of the design. By extension, this implies that the design is predominantly econo-technical, with minimal social components, which by extension implies that a quantitative (testable) representation of the design produces a plausible outcome. In both articles, the designs were arguably changes in maintenance scheduling logic, which, once implemented, would be embedded in respective (back-end) scheduling systems, making them invisible to the user, whose behavior they were intended to affect.

\subsubsection{Implementation}

As the design is implemented, testing and re-design are the main activities. The designer focuses on evaluating the outcome of the design and understanding the behavior of the user. Where appropriate the designer then engages in re-design, leading to further maturing of the design. In terms of framing, the user is now the entity of interest, as his or her perception of, and interaction with the design reveals a re-design opportunity related to emergent design behavior. In the research leading to article 3, we found that some users viewed the design as a "hardware store" (which was the intention), while some viewed it as an "emergency inventory". The latter view lead to consumption patterns which were not beneficial from the perspective of the suppliers, forming a threat to the long- 
term viability of the design. This finding prompted a re-design in the form of emphasizing the intended purpose of the design in the company instructions.

Design implementation also reveals systemic effects of the design, i.e. how the design interacts with its economic, technological and social context. Here, a difference between ideal and real outcomes may prompt a re-design in design behavior, in order to change how the design interacts with its context, improving systemic performance. Another possible approach for re-design entails changing the design border, effectively including a part of the context into the design, as it is changed to accommodate the ideal design, in an attempt to improve systemic performance. An example a systemic re-design opportunity can be drawn from the research leading to article 3 , where the change in relationship between supplier and construction site changed from unilateral to bilateral (to some extent even trilateral), causing problems which were not considered ${ }^{19}$ in the preimplementation phase of the design (cf. Tanskanen et al., 2009). This is summarized in the following finding on how designs mature in implementation:

Implemented designs mature through re-design intended to improve emergent and systemic performance

\subsubsection{Re-implementation}

When designs are transferred from their original context to similar contexts, the original designer is arguably seldom involved. The transfer implies the involvement of a new designer, here termed as a secondary designer. In the new context, the design goes through similar pre-implementation and implementation phases as in the original context, with similar activities. However, instead of search activities, the secondary designer engages in what could be characterized as learning activities, where the secondary designer's framing of the design is based on the real design and outcomes in the originating context. This was tangible in the research leading to article 4 , where the designers in the studied contexts based their perception of the ideal design on the (to some extent glorified account of the) real design in the originating context. In all cases, this led to a gap between expected and realized benefits of the design, where (mainly) expected benefits were reduced as the design was applied to the new context.

Based on the above, the key lesson for the secondary designer was not so much about what the original design is, but rather, to what extent the original context is reflected in the design, and what the implications of that are. The design matures through the same processes as above, framing, building and re-design, resulting in a design that is fit for context. The resulting applied design is described in terms of applied structure, applied behavior, applied borders and contingent outcomes. These findings lead to the following finding on how designs mature in re-implementation:

Re-implemented designs mature through re-design to fit context

\footnotetext{
${ }^{19}$ One plausible explanation of this could be the vendor managed inventory-reliant framing of the original solution, which tends to emphasize the change in supplier responsibility (cf. Kaipia, Holmström, \& Tanskanen, 2002) as opposed to the change in customer responsibility.
} 


\subsubsection{De-implementation}

With enough applied designs, one can start to deduce rules for the context-dependency, i.e. contingent nature of the design, revealing the "underlying $\mathrm{OM}$ principle" embedded in the design. The deduced rules can also be expected to gradually reveal the smallest common denominator of implemented (both original and non-original context) designs, effectively sketching out a generic (and readily generalizable) design, on top of which context adaptations are built (cf. Alexander et al., 1977). This is when the design becomes independent of context, implying that the design is effectively de-implemented. The designer at this stage is the consultant or the academic with a pragmatic knowledge interest, seeking to formalize the pre-implementation and implementation stages, so that the design (noun) could be reproduced without the need for design (verb). Article 4 comprised an initial attempt to a generic design description, where the research led to a rule-based description of CBM, describing the contingence of design purpose and form, deduced from the applied designs. This is summarized in the following finding on how designs mature in de-implementation:

De-implemented designs mature through their process of reproduction becoming formalized

At this point, ceteris paribus, the design would be considered fully mature, and as having no more knowledge to offer. However, as contexts change, even a mature design will eventually show room for improvement, potentially presenting new opportunities for knowledge creation.

\subsection{Extracting knowledge from maturing designs}

Different types of knowledge is created in different phases of design maturity. In pre-implementation, the interaction between designer and context has the potential to create new conceptual knowledge in terms of context and design framing, which advances the design. In the implementation phase, exposure of design to context reveals deficiencies in initial framing, and tests emergent design properties. In the re-implementation phase, the context-dependence of the design is tested, providing knowledge of context-dependency of both design and outcome. All of these steps rely on knowledge emerging in interaction (of designer or design) with context. The final de-implementation phase is the pinnacle of the pragmatic inquiry, where the design itself can be theorized, with the pragmatic purpose of describing when, where, how and why the design ought to be implemented. As the design theory should answer whether the design ought to be implemented in a given context, it is arguably generalizable, despite the design not necessarily being generally applicable. In this section, I will discuss the knowledge contributions of the empirical research and relate them to the derived conceptualization of design maturity. 


\subsubsection{Pre-implementation}

Context and solution framing is the prime source of new knowledge in pre-implementation. Knowledge created at this phase is conceptual, embedded in the designer, induced by context, taking the form of (in pragmatic terms) a useful, novel way of viewing the context. Useful here in the sense that it facilitates the process of creating the design, in which the value of the new knowledge is eventually manifested. Whether or not knowledge will in fact turn out to be valuable is a significant concern in contributions based on pre-implementation designs, and will be further discussed at the end of this sub-section. In the research leading to articles 1 \& 2 the pre-implementation designs were testable representations of the would-be implemented designs, represented by a complex spreadsheet (article 1) and a simulation model (article 2).

In the research leading to article 1 , I claim two knowledge contributions. The first of these arose when context data was being manipulated in an exploratory fashion, leading to the realization that reliability theoretical propositions could be applied to service scheduling on an aggregate fleet-level. In effect, this was a novel application of reliability theory (increasing the value of extant knowledge) and a novel layer to service scheduling (new knowledge). The second contribution arose from the reliability theoretical framing, which led to the insight that SPC could be used in creating a dynamic scheduling process on top of the measure (design) derived from the first contribution. This entailed developing a novel approach to SPC in order to accommodate relative time (extending extant knowledge). Further, the novel design for performance measurement and control lead to the realization that the measure also was an aggregate representation of the customer process, implying SPC was being utilized to control a customer process in a service context, which was a novel application of SPC (reframing extant knowledge).

In the research leading to article 2, I also claim two knowledge contributions. The first of these, arose from an initial study in the same context (Öhman, Laine, \& Holmström, 2016), which made us question the common assumption - in both practice and research related to the context - that maintenance should always be scheduled as late as possible ${ }^{20}$. The underlying problem related to this was workload variance (amplified by unplanned repairs), with resource flexibility as the prevailing practice for coping with the variance. The constructed simulation model allowed us to experiment with introducing temporal flexibility as a complement to resource flexibility, showing that the "as late as possible" scheduling approach produced inferior results. In effect we thus questioned the prescribed solution (prevalent knowledge), showing the viability of a new solu-

\footnotetext{
${ }^{20}$ In the course of the research this conception was traced back to the 1970's (cf. Boeret, 1977), when aircraft maintenance programs were so extensive that it gave rise to the mantra that aircraft spend more time in maintenance than they do in the air. During this era, also Reliability Centered Maintenance (RCM) emerged as a series of developments aimed at reducing the time that aircraft spent in maintenance.
} 
tion-space based on the complementary solution of introducing over-maintenance into the schedule, which could then be postponed to cope with emergent workload $^{21}$.

The second contribution arose from the framing of the design as an overmaintenance buffer, which led us to relate our research to prior work in supplychain theory with similar problems of amplified variance (Towill, Zhou, \& Disney, 2007), also in services (Akkermans \& Voss, 2013). This led us to question another generally held assumption - that services cannot be stored for later use (cf. Moeller, 2010). This in turn led to the realization that the over-maintenance buffer was conceptually equivalent to a frontlog, which was essentially a service inventory - not in the sense that service production and consumption would be separated, but in the sense that production occurs before demand is imminent. While challenging the generally held assumption, the frontlog also challenges the manufacturing versus services divide in OM, which could have profound theoretical implications. In conclusion, the maturing designs in articles 1 \& 2 contribute to current knowledge through:

- Opening a new solution space in context.

- Opening a new application space in theory.

Both of these types of contributions can be motivated from the pragmatic approach to knowledge creation. The first, on the grounds that neither article claims a superior, substituting solution, but rather that existing solutions should be complemented with the novel design to reach superior outcomes. The second, on the grounds that increasing the range of applications of a theory, increases the utility of that theory. The two are tightly interlinked however, and mutually inclusive, as illustrated in Figure 9.

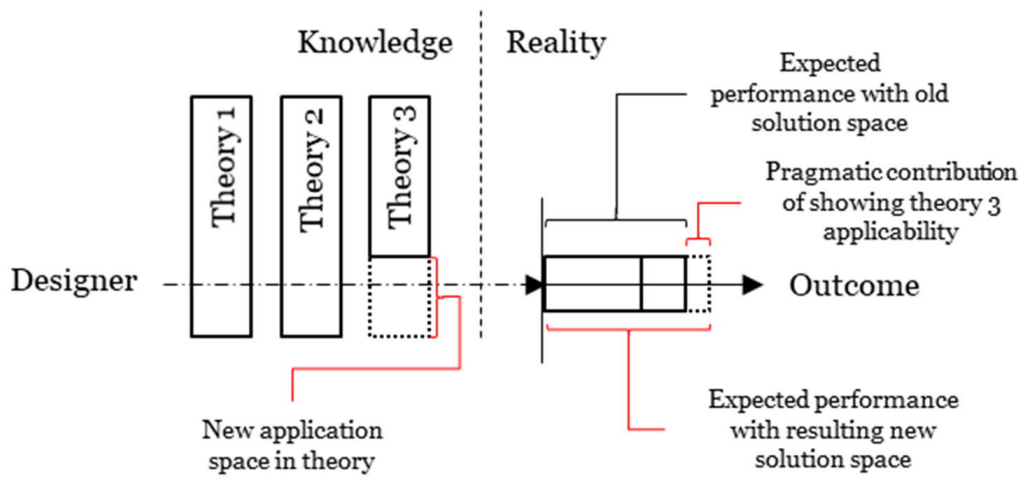

Figure 9 - Knowledge creation in pre-implementation

Given that the testable design representations are simplifications of the real systems they represent (Law, 2003), there are limits as to what knowledge can be extracted from them. More specifically, implementation generated knowledge, such as the emergent and systemic behavior of the design, cannot be derived from testable representations. In other words, the validity of

\footnotetext{
21 "At its heart, every operational innovation defies an assumption about how work should be done" (Hammer, 2004, p. 91)
} 
knowledge extracted in pre-implementation rests on an assumption of negligible design emergence. Further, despite negligible emergence, the ideal outcome produced by a testable representation cannot be readily interpreted as a real outcome as it does not capture systemic performance. These are factors, which need to be discussed when assessing pragmatic validity. In other words, knowledge contributions based on pre-implementation designs can be expected to arise from econo-technical designs with thorough empirical grounding, designed by a designer with in-depth understanding of the context.

\subsubsection{Implementation}

In the implementation phase, new knowledge is created as the designer seeks to explain the difference between the expected ideal outcome and the observed real outcome, including explanations of potential unintended outcomes. In essence, through implementation, the design induces knowledge from the context, revealing the rationally bounded designer's gap of understanding, testing assumptions related to design borders and emergent design behavior. While necessary for validating designs with significant emergent behavior and/or systemic performance, implementation also serves as further validation of knowledge claims made based on the pre-implemented design in the intended context. Based on the analogy "if you want to understand a system, try to change it" (van Aken, 2004, p. 241) it could be assumed that novel designs may at this stage also contribute to more fundamental theories of economic organization.

In the research leading to article 3 , we started with the assumption that the design had emergent behavior in the sense that the perception of design stakeholders (mainly users) would define their interaction with the design. Based on the views of the stakeholders, we were able to deduce three contributions as to explain the adoption of logistics innovation. First, incongruent views in how the design was framed by its stakeholders were shown to lead to differences in design performance, as expected. Second, the study uncovered a more sinister development in the social fabric between the stakeholders involved in the logistics design. Due to the design, a formerly unilateral relationship between construction site and supplier now became bilateral, where the construction site suddenly had a share of the responsibility in ensuring successful supply. This led us to observe indications of a vicious cycle (Oliva \& Sterman, 2001) where construction site's misbehavior was patched by additional supplier work, leading to increased costs and stock-outs, undermining the long-term viability of the design. Finally, due to the nature of the context, the design was re-implemented on a project-by-project basis, which highlighted the importance of introducing a standardized set-up process, an aspect not sufficiently addressed in the preimplementation phase. These contributions highlight two principal knowledge contributions emerging from context:

- Explanations of emergent design performance in context.

- Explanations of systemic design performance in context. 
Here the systemic design performance denotes outcomes, which are essentially side effects of introducing the design. The changes in stakeholder relationships in article 3 serve as an example in point, in which the systemic effects of the design were not fully understood before it was implemented. Another illustrative example could be drawn from article 2, where decreased reliance on resource flexibility could be expected to reduce workload in the resource management function - this was however not the primary purpose of the design, and hence not included in the testable representation. From the perspective of pragmatic knowledge creation, the utility of an explanation-contribution (on both emergent and systemic performance) is that it either prompts a re-design, or that it simply replaces the gap in understanding with a gap (or variance) in performance, removing the need to search for complementary explanations.

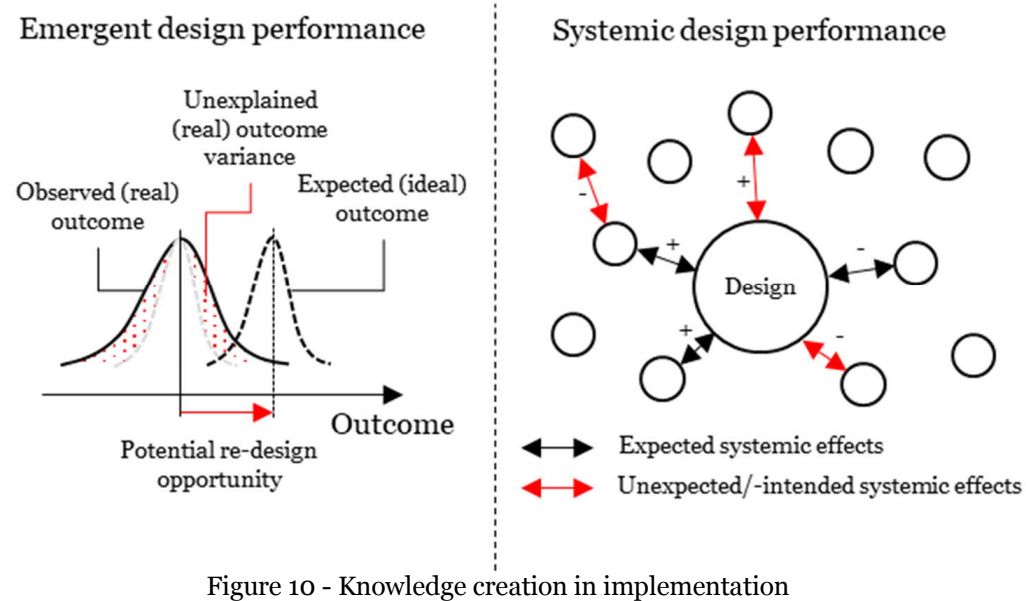

\subsubsection{Re-implementation}

As the design is re-implemented in a non-original context, the design-embedded context assumptions (based on which the original design structure, behavior and emergence are built) are surfaced. Hence, re-implementation is essentially a test of the applicability of the original problem or opportunity framing in the new context. The objective of knowledge creation in re-implementation is explaining variance between contexts in terms of design purpose, form and outcome. Theories that explain variance also tend to explain similarity, which means that re-implementation gradually leads to de-implementation, as the core of the design, which remains the same throughout contexts begins to emerge. The design is likely to be re-implemented by a secondary designer, which is different from the original primary designer. The secondary designer is a valuable source of knowledge as he/she develops the design through pre-implementation $^{22}$ and implementation (with corresponding knowledge-creation opportunities) in the context of re-implementation.

\footnotetext{
${ }^{22}$ Here with the distinction that both solution and context are given, but the solution is not necessarily readily applicable to context - implying that the secondary designer engages in design learning and reframing.
} 
In the research leading to article 4, we identified a number of contingencies, which explained context-induced differences in why and how the studied design was implemented. Finding and explaining these differences is in itself a contribution (Sousa \& Voss, 2008), and we found that many of the differences in how the design was implemented could be explained by organizational theories related to information (Galbraith, 1974; Tushman \& Nadler, 1978) and knowledge (Grant, 1996b, 1996a). However, we also observed that most of the differences in why the design was implemented, as well as some differences in how, were not explained by the formal theories - hinting of potential for a more profound theoretical contribution. Hence, the contributions to knowledge from re-implementation are:

- Explanations of contextual differences in why the design is implemented.

- Explanations of contextual differences in how the design is implemented.

While the outcome of a re-implemented design is of interest, it is a dependent variable of why and how the design is implemented. The point here is that, based on the outcome alone, one cannot determine how successful an implementation is, or how well a design is suited for the contest in which it is being re-implemented. Hence, explanations are necessarily founded in an understanding of why and how the design is implemented. Further, failed implementations should be considered at least equally interesting to successful implementations, as they provide evidence of limitations in general applicability of the design.

Design purpose

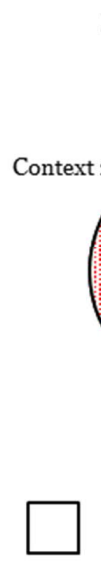

Differences in why the design is implemented
Design form

Differences in how the design is implemented

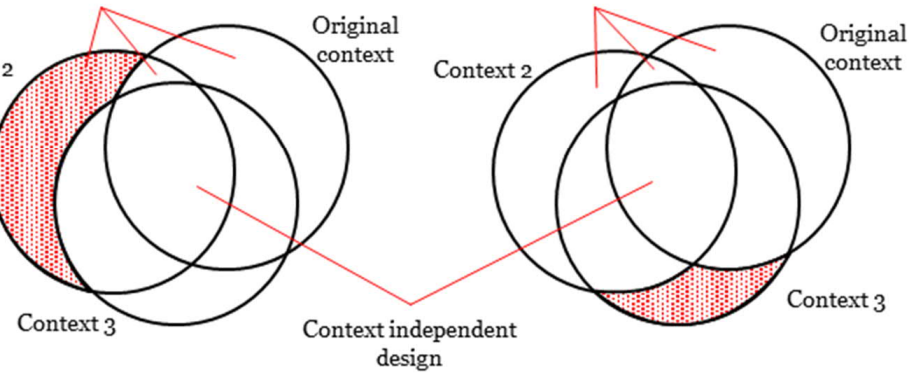

Explained by formal theory
Not explained by formal theory Figure 11 - Knowledge creation in re-implementation

\subsubsection{De-implementation}

As the scope of contexts in which the design has been introduced broadens, the limitations of the design are pegged out through context-dependent (why- and how-) rules. In this process the problem/opportunity formulation (why), and by extension the design (how) is detached from context, leading to generic design 
knowledge, which is universally applicable and understandable - not however implying that the design would be universally applicable. In research leading to article 4 a generic design begun to emerge, as rules emerging from the studied contexts were supported by formal theories, implying at least partial generalizability of the findings. These rules (or design patterns) built around a focal generic design are the objective of pragmatic knowledge creation in the de-implementation phase, and can be expressed as:

- A generalizable description of the design.

- Prescriptive knowledge of whether, why and how the design should be implemented in a given context.

Once the prescriptive knowledge that can be drawn from re-implemented designs begins to saturate, the design can be considered mature in the sense that its implementation no longer generates new knowledge. This situation could be equated to what Gregor \& Hevner (2013) characterize as routine solutions - i.e. applying a known solution to a known problem - with no surprises or unaccounted variance in purpose, form or outcomes. However, as noted in section 4.1.4, as contexts change over time, the generalized description may someday no longer hold, opening an opportunity for researchers to "re-visit" the design - with the design providing a window to how the world has changed.

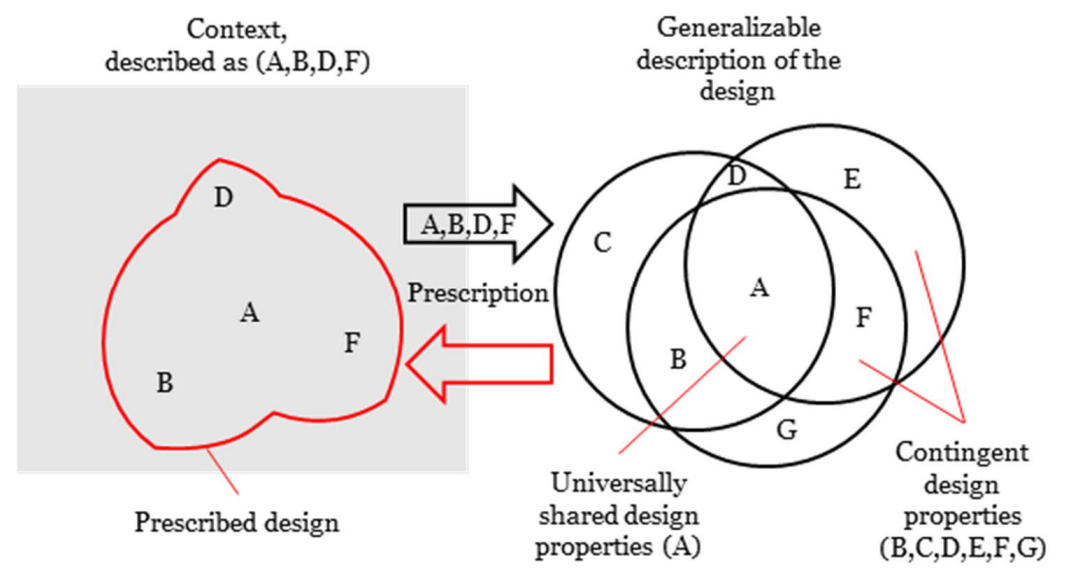

Figure 12 - Knowledge creation in de-implementation

The de-implementation phase may also involve further conceptual re-framing work, as gathered evidence may shed light on design parsimony and possible kinship with other (OM) designs, such as the similarities between CBM and JIT production (cf. Duclos, Sih, \& Lummus, 1995) noted in article 4. Knowledge created in this phase would arguably enable a wider exploration of design genealogy (cf. Holweg, 2007), and by extension serve as a foundation for an OM practice(s) theory (cf. Bromiley \& Rau, 2016). 


\subsection{Maturity and knowledge creation in contemporary OM DS}

Before moving on to the discussion, I will reflect the concept of design maturity as I have defined it in this section, against contemporary OM DS research introduced in section 2.3. Two questions arise from this reflection. First, I find that the question of when a design is implemented offers some room for interpretation, and consequent methodological elaboration. Second, I find considerable diversity in the knowledge "extracted" through the designs, which is in retrospect natural, as a typical OM DS research article in practice covers several stages of design maturity. In other words, it would seem natural that an article reporting an implemented design also claims contributions that I have associated with pre-implementation.

\subsubsection{Design maturity in contemporary OM DS}

Of the 17 OM DS articles reviewed, eight articles were deemed to present designs that were in pre-implementation maturity, while another eight articles presented designs that were in implementation maturity. The one remaining article, Holmström et.al. (2010) arguably discusses design re-implementation in a number of context (project delivery, industrial asset management and industrial service operations). This being said, however, all designs to some extent underwent empirical evaluation, which creates ambiguity in the distinction between pre-implementation and implementation. This ambiguity is tangible in some articles that develop frameworks or typologies. For example; The maturity profiling design created by Jääskeläinen and Roitto (2015) is implemented in a sense of validation, as they show the viability of their design through conducting a survey, in which they, based on 271 questionnaire responses, profile the performance management maturity of the organizations of their respondents. The same design is, from my perspective, not implemented in a pragmatic sense, as the authors (Jääskeläinen \& Roitto, 2015) report no research on how the respondents and their respective organizations would act upon understanding their performance management maturity.

This same observation holds for other designs which consolidate prior research with a pragmatic objective (cf. Pournader et al., 2015). In a sense these studies could also be seen in terms that they create design structure based on prior research or empiry (cf. Hinkka et al., 2015; Soinio et al., 2012), and validate this structure, but offer very little in terms of design behavior or emergence. A similar question arises in the article of Finne (2018), which I classified as implemented. In his work Finne (2018) redesigned an OM course based on professional service management principles, and brought about tangible change in the course which he was able to evaluate based on student feedback. The design ("a six-step systematic approach") however, was arguably inspired by literature and deduced in the process of bringing about the change in the OM course, which leads to the peculiar distinction where the design was not something that was implemented, but rather a result of the implementation. Following this reasoning, despite the tangible (and positive change) brought about in the research context by Finne's research (2018), the pragmatic validity of the design cannot 
in strict terms be deduced from the process of its creation, but is reliant on implementation where the design would exist before implementation. Or can it?

The distinction between implementation and re-implementation also offers room for interpretation. In addition to article 3 in this dissertation, also the research articles of Groop et.al. (2017) and Kaipia et.al. (2017) highlight this issue, as both describe design implementations, which are respectively either affected by, or contrasted against another implementation. In the case of Groop et.al. (2017), the authors describe a process where design development was halted in one case, only to be resumed based on encouraging results in another case implying a process where design implementation was affected by a prior implementation. In Kaipia et.al. (2017) the design was implemented and benefits materialized in one case. However, the design was also introduced in another case, in which the implementation was discontinued - highlighting the situation where one viable example of an implemented design may be accompanied by valuable re-implementation knowledge from failed implementations. These examples highlight the fluidity of the concept of design maturity, and indicate likely benefits of considering design maturity as a dually evolving continuum of solution maturity and problem maturity, as discussed in section 2.1.4.

\subsubsection{Knowledge created in contemporary OM DS}

Many of the reviewed studies (Abaunza et al., 2018; Finne, 2018; Groop et al., 2017; Öhman et al., 2015) (consisting of both pre-implementation and implemented designs) contribute through applying OM theory in a novel context indicating a pragmatic contribution though improved context outcome(s) while broadening the application space of theory. Evidence of emergent and systemic performance is presented in several articles, but only two articles develop these to explicit contributions (Groop et al., 2017; Tanskanen et al., 2015). Further, a number of articles contribute through elaborating design contingency in terms of why and how a design works in different contexts (Holmström et al., 2010; Kaipia et al., 2017; Kjellsdotter Ivert \& Jonsson, 2014; Meyer et al., 2014; Tanskanen et al., 2015), often through CIMO-based propositions, sometimes taking a quite prescriptive tone ${ }^{23}$.

While all the knowledge contributions discussed above can be found in section 4.2, six articles in the reviewed sample argue a knowledge contribution, which I have not previously recognized. Based on my interpretation, the authors in these six articles argue that the designs brought forth in them contribute through consolidating prior research with a pragmatic objective. While in line with the objective of design science in bridging the gap between research and practice (Holmström et al., 2009), I would argue that four of these six articles, despite empirical validation, fail to demonstrate pragmatic validity. This, in the sense that their design (which is that of prior research turned into a model, typology or framework) would actually be able to bring about a change for the

\footnotetext{
${ }^{23}$ Making the distinction between re-implementation and de-implementation knowledge somewhat ambiguous
} 
better, in practice. The two exceptions elaborate on and partially test for pragmatic validity (Busse et al., 2017; Reinerth et al., 2018). This leads to a justified question of whether designs purely synthesized from prior research should be regarded as design science, and if so, what would be the requirements for ensuring pragmatic validity? Finally, two of the early DS in OM articles, despite developing more or less tangible designs with good outcomes, in my opinion fall short in theorizing their findings (Moon \& Ngai, 2010; Tanskanen et al., 2009). 



\section{Discussion}

"As creatures of bounded rationality, incapable of dealing with the world in all of its complexity, we form a simplified picture of the world, viewing it from our particular organizational vantage point and our organization's interests and goals"

(Simon, 1996, p. 44)

So, what is our vantage point as academics? What are our interests and goals? Are we here to change the world, or should we merely try to understand it? These were the questions posed in the introduction - questions which have been debated for decades in the field(s) of management. Design science takes a stance on this point; we are here to change the world, and through changing it, we will understand it. Design science is also an inclusive science - the quest is not to arrive at a single best way to explain (and predict) reality, but rather the complementary integration of available ways until adding new knowledge does not add to understanding the phenomena at hand. The hands-on, empirically grounded approach and commitment to pragmatic validity, built on an inclusive view of knowledge, has raised hopes for DS providing a solution to the frequently questioned relevance of OM research (Holmström et al., 2009; van Aken et al., 2016). However, the methodological discussion in the emerging stream of DS in OM has so far sought to establish and relate itself to the "traditional ways" of doing science - leaving much of the "how to" discussion on an anecdotal level.

Based on the appended OM design articles, this thesis elaborates on the "how to", through identifying and discussing methodological issues which are emphasized in the field of OM. Through a perspective of design maturity I explore how and what knowledge is created when what ought to be becomes what is - finding that all phases of design maturity have the potential for creating new (pragmatic) knowledge. Further, this exploration touches and elaborates on several methodologically important aspects of DS in OM, which have previously been discussed in an anecdotal fashion, such as the implications of the socio-technoeconomic nature of OM designs and design emergence as a key component of this. Finally, this exploration identifies a number of new methodological issues in OM DS, which have so far escaped wider discussion and elaboration - also outside of the field of OM - such as the importance of distinction between design and context, and the role of the designer as a source of knowledge. In this 
section, I will discuss the significance and implications of this methodological exploration, followed by a look forward on the future of DS in OM from my current vantage point.

\subsection{Contribution to Design Science in OM}

In this thesis, I explore how designs mature, and how new knowledge is generated in the process. Although being hesitant in using the word framework due to its ambiguity ${ }^{24}$ I do claim that I have, through this thesis, given a meaningful, useful and novel structure to the process through which a design brings about change in the world. The framework is meaningful, as it delineates the relationship between design maturity and the pragmatic quest for knowledge creation - rooting it in the methodological foundations of design science. The usefulness of the framework is rooted in its meaningfulness, as the framework is primarily intended to give structure and coherence to the methodological debate on DS in OM. Finally, the novelty of the framework is, as always, relative - and at least to some extent, in the eye of the beholder. Relating the framework to the maturitybased frameworks presented in Figure 4, page 22, I would not claim that the derived framework gives structure to the design process, as does Peffers et.al (2007), nor is its objective to describe the design science path to formal theory, as in Holmström et.al. (2009), and finally, in contrast to van Aken (2004), although being rhetorically centered around implementation, the framework does not require a de facto implementation. In summary, current framework complements the above by emphasizing that new knowledge can be derived in all phases of design maturity: pre-implementation, implementation, re-implementation and de-implementation.

In pre-implementation, the emerging design is argued to be a product of the context "extracting" knowledge from the designer. The knowledge produced at this stage is characterized by a dual extension of the solution-space in the context and the application-space in theory. Based on a pragmatist epistemology, a contribution in the pre-implementation phase increases the utility of extant knowledge, through applying it in a novel way. In implementation, the design's intent is put to the test, as the design extracts knowledge from the context, inviting explanation of deviations from intended outcomes. The knowledge produced at this stage is characterized as explanations of emergent and systemic performance. From a pragmatist inquiry perspective, the knowledge created (or leveraged) in this phase improves the predictability of design outcomes and highlights opportunities for improvement through re-design. While explaining (especially emergent) performance, knowledge produced at this phase may be informed by, and by extension challenge (Hevner et al., 2004) formal behavioral and social theories.

\footnotetext{
${ }^{24}$ The word framework is used in two slightly different meanings. On one hand, a framework can denote a descriptive tool - "a basic conceptional structure (as of ideas)" (https://www.merriam-webster.com/dictionary/framework, retrieved 5.4.2019). On the other hand, a framework can have a broader meaning as a normative tool - "a system of rules, ideas, or beliefs that is used to plan or decide something" (https://dictionary.cambridge.org/dictionary/english/framework, retrieved 5.4.2019)
} 
In re-implementation, the design (again) extracts knowledge from the context in which it is re-implemented. The knowledge that is produced at this stage probes context assumptions embedded in the design, seeking to explain differences in why and how the design is implemented in non-original contexts. Again taking the perspective of the pragmatist inquisitor, the utility of the knowledge produced at this stage is that it has prescriptive use in further re-implementation. Further, explanations of differences in why and how designs are implemented may test and perhaps even offer explorative extensions of formal economic and organizational structural theories. A contribution in this phase is derived through studying a known solution to a known problem, in contrast (but not contradiction) to what Gregor \& Hevner (2013) posit. In the final phase the design itself becomes formal knowledge (in the sense that the prescriptive design-knowledge is generalizable - not however implying that the design is generally applicable), as it is effectively de-implemented from context. Knowledge at this phase takes the form of a generic description of the design, with contextdependent rules prescribing the purpose, form and outcomes of context-specific implementation. The pragmatic utility of knowledge produced at this stage is that it removes the need for design (as a process) when implementing the design (as an artefact). Further, I have argued that when accumulated, such generic designs would result in a genealogy of OM practices (cf. Holweg, 2007), ultimately leading to a design-based practice(s) theory of OM.

\subsubsection{Conceptualization of designs for knowledge production}

In contrast to other fields where design science has gained traction (IS, organization studies), $\mathrm{OM}$ is arguably one of the more challenging when it comes to the heterogeneity of contexts, and by extension designs. As problem framing is solution framing in disguise (Simon, 1996), and vice versa, how we describe and conceptualize our designs becomes an integral aspect of design science methodology. I have discussed OM designs as techno-socio-economic systems, mainly to argue for differences in the methods required for design validation, which I will summarize in section 5.1.2. Inspired by Simon's (1996) work, I have also discussed conceptualization of designs through structure, behavior and emergence. This way of conceptualizing designs is argued to facilitate design, as arriving at new solutions requires alternating between state and process representations of reality (Simon, 1996). Further, inspired by Gregor \& Jones (2007) I have discussed designs (especially in the re-implementation phase of design maturity) through form and purpose ${ }^{25}$. It seems evident that design conceptualization serves different purposes at different stages of design maturity. On the other hand, when contributing to academic discussion through design science, design conceptualization is to some extent dictated by the theoretical traditions of the domain for which the contribution is intended. A review of prior DS in OM revealed a number of articles that present designs consolidating prior research in the field, which would seem good from the perspective of creating de-

\footnotetext{
${ }^{25}$ Note that Gregor \& Jones (2007, p. 325) include "constructs" as one of their design theory components
} - referring to it as "representations of the entities of interest" in the design theory. 
signs that resonate with theory. However, as I discuss in section 4.3.2, this approach calls for evaluating and testing not only empirical validity, but also pragmatic validity.

One aspect of conceptualization, design boundaries, is arguably of special importance in OM DS given the heterogeneity of contexts. While many authors mention design boundaries (Gregor \& Jones, 2007) or interfaces (Simon, 1996; van Aken et al., 2016) either explicitly or implicitly, very little elaboration is done on the subject. As OM designs are implemented, they are embedded into the system that is operations on several different levels - this might make the distinction between design and context vague and ambiguous. Especially when designs rely on emergence, and when the design is expected to have systemic effects. While it would be tempting to limit design science in OM to designs with "short causal relations between intervention and outcome" (van Aken et al., 2016, p. 6), this could risk ruling out radical OM designs which drive fundamental change. The solution based on the research presented in this thesis would rather be to acknowledge the ambiguous nature of the design-context border, or interface, and introduce a practice of explicating and discussing design interfaces $^{26}$ in academic reporting. To what extent this principle could be extended to how design propositions are formulated ${ }^{27}$ is a topic for further elaboration beyond this thesis.

Spinning further on design boundaries, an important subject for further methodological elaboration in DS is its relationship to case study methodology. Most contemporary DS research in OM resorts to case study methodology to some extent, perhaps mainly due to relatable concepts and rhetoric, perhaps partly is search of legitimacy. At the same time, the discussion above challenges even the most basic interpretation of what case studies are - the designation of a boundary between context and object of research, let alone that this boundary should be between a firm and its business context. Assuming that the design will always be the unit of analysis in the case, I will leave this discussion with a number of questions, the answers to which would clarify the relationship between case studies and DS. To what extent can we build on case study methodology when a) the boundary between design and context cannot be determined a priori, b) the boundary may change during the research process, c) the boundary between design and context may differ between "cases" and d) the purpose of the design may differ between "cases"? Considering the heterogeneity of case study research (Ketokivi \& Choi, 2014), I would not expect any unsurmountable challenges in clarifying the relationship of case studies and DS in OM.

\subsubsection{Methods for producing knowledge through designs}

Van Aken et.al (2016) emphasize that Design Science is a research strategy, implying that DS does not contain notions of preferred or acceptable methods. I have argued (supported by articles $1 \& 2$ in this dissertation) that designs can

\footnotetext{
${ }^{26}$ With the purpose of this discussion varying depending on design maturity.

${ }^{27}$ For example the distinction between Context and Intervention in the CIMO structure, where the Mechanisms could be equated to descriptions of interaction, while at the same time being embedded in context.
} 
create knowledge before being implemented in context, through methods of quantitative analysis and/or simulation, based on context-generated data. I have also argued that establishing design validity in pre-implementation is possible as long as the design has negligible emergent properties. In contrast to Operations Research (cf. Koskela, 2017), this does however not remove the need to gain an extensive in-depth empirically grounded understanding of the context for which the design is intended, and from where the data originates. In practice, this implies a need to also gather qualitative data in order to understand and contextualize the evidence, and by extension the design.

In the implementation phase, field-testing (van Aken, 2004) not only (typically) provides tangible evidence on the techno-economic outcomes, but also reveals the effect of social and cognitive components of the design. While the emergent performance of the design probably can be distinguished from quantitative data describing the outcome of the design, understanding emergence requires seeing the design from the perspective of its users and stakeholders. For this purpose, qualitative methods such as observation and semi-structured interviews were shown to be suitable (article 3). Finally, in the re-implementation phase all of the methods above are likely to provide important evidence. Re-implementation naturally necessitates studying multiple contexts, and although not used in article 4, combinatory analysis (cf. Grandori \& Furnari, 2008) could provide a useful approach for understanding "design chemistry". Of special importance would however seem to be access to the secondary designer, in order to probe the effect (through qualitative research) of his or her perception of the design and its origins (article 4).

An issue of special concern is validation of designs where the effect on operations is incremental and/or probabilistic. In article 2, we showed that a relatively small change in scheduling would result in a significant average economic impact over time. To reach this conclusion we simulated over 2000 years of aircraft maintenance. This exemplifies a challenging problem from a design perspective - one where a definitive and exhaustive analysis of the effect of implementation would have to span over decades to account for natural variability in the outcome. In summary, regarding methods for DS in OM, the conclusion is; the more the merrier, on the grounds that design validity is always reliant on an in-depth understanding of the context. Further, designs with negligible emergence are potentially testable through analytic methods, using data originating from context, while designs with emergent properties need to be implemented to some extent to be able to accumulate evidence on stakeholder perceptions.

\subsubsection{The designer as a source of knowledge}

The final observation emerging from the conducted research (based on seeing design as an activity of framing and re-framing) is the importance of understanding the designer (framer) in understanding the workings and embedded assumptions of the design. With OM harboring several domains of inquiry, with different nuances in theoretical traditions, OM design scientists may arrive at (even radically) different solutions for OM problems/opportunities, depending 
on their background. While this theoretical diversity can be a strength, it creates a need for self-reflection when evaluating and communicating designs - i.e. asking "how did what I know affect how I solved the problem?", and by extension "what underlying assumptions may affect the (long-term) outcome of the design". As an illustration of this I offered the challenges of the design reported in article 3, which could (at least in retrospect) be deduced from the backgrounds of the original designers (cf. Tanskanen et al., 2009).

The designs we create reflect our knowledge and ambitions - we as researchers make sense of the world through framing, affected by our theories - hence, when we study a phenomena through design, we also study our own conception of the phenomena. In an embedded sense, we test the theoretical foundation we have accumulated, ideally using that knowledge in a complementary fashion, letting the problem induce the framing, rather than vice versa. Respectively, when we study designs made by others, we also probe their view of the world. In conclusion, I put forth that, due to a presumed heterogeneity and complementarity in the ways in which OM problems can be framed, DS in OM should take a habit of reflecting on the background and knowledge-base of designers, whether that be done through self-reflection or semi-structured interview.

\subsection{Limitations and practical implications}

Given the limited number of studies included in this dissertation, I feel it would be my obligation to state that the results are not readily generalizable. I will instead choose to highlight that given the limited number of design studies appended, the methodological discussion here is by no means exhaustive, nor is it meant to be. I hope the ideas conveyed in this thesis eventually serve as building blocks for a bridgehead in developing a vibrant methodological discussion of DS in OM. I have highlighted a few aspects that I, based on the research I have conducted, believe to be crucial in OM DS methodology. Most of the ideas presented in this thesis can be, and I hope that they will be, further developed - as they seemingly leave much room for further methodological scrutiny.

As for practical implications, this thesis set out from the discussion, and perceived lack of OM research relevance. If this thesis can at all contribute to the establishment and development of DS in OM, I believe the implications for practice would be positive. Naturally, the studies that comprise this thesis have their individual contributions, having in some cases brought concrete change for the better, in others, affected and broadened the mindsets of involved practitioners. However, also this methodological elaboration combined with the findings in article 4, point at a useful practical guideline; when considering the adaptation (re-implementation) of an OM (best) practice, managers would do well in cultivating their understanding of the context in which it originates. This, as the pessimistic economist would say that the practice probably emerged in the context where it was most needed, implying that it will probably be less useful wherever else it is implemented. 


\subsection{On the future of Design Science in OM}

Looking forward, I expect design scientists in OM to engage in two fundamental questions with methodological implications, which may not have an answer, but should be debated. The first question is related to DS as a problem-solving discipline (Holmström et al., 2009), aimed at creating novel solutions to unsolved (wicked) problems. What actually constitutes a novel solution? There was order tracking before RFID was introduced in supply chains (Holmström et al., 2010) - it was just less granular and more laborious. There was a small-item inventory on the construction sites before the introduction of On-site shop (Tanskanen et al., 2009) - it just had more stock-outs and tied up more capital. There was a way of allocating caregivers and handling resource shortages before Groop et.al. (2017) introduced their design - it was just less efficient. So are these new solutions as a matter a fact improved solutions? The intent here is not to argue that the mentioned designs were not novel or innovative - but rather to highlight that novelty is a relative concept, which introduces subjectivity when used for evaluating research. Further, as highlighted in this thesis, solutions can be both new to context and/or new to theory. In effect, although novelty is a cornerstone in the DS pragmatic quest for knowledge, the evaluation of it may (and should) spark debate.

The second question is related to the boundary- / interface-issue highlighted in section 5.1.1. As artifacts in OM are defined (and better described) as interventions, are there limits of feasible design-based interventions in OM? Servitization (Oliva \& Kallenberg, 2003) for example is a strategic differentiation of a manufacturing firm, where it increases the emphasis of services in its offering (Ulaga \& Reinartz, 2011). The OM implications of this change are arguably significant (Baines \& Lightfoot, 2013) and for any company considering this change, it undoubtedly presents a wicked OM problem and a presumably massive intervention - how should we go about providing services, when we are used to producing products? Could this problem have been approached through design science? If not - why not? If yes - is there something that could not? Based on Simon's $(1962,1996)$ work it would probably be advisable to split a big problem into a set of smaller problems, respectively producing a set of smaller solutions, which together comprise the big solution. Yet, the most influential designs in OM are what could be described as "big solutions" (Holweg, 2007; Womack, Jones, \& Roos, 1990). Here I see room for methodological debate, where one objective will be to clarify the relationship between DS and the substantial body of methodological literature on case studies.

Finally, I have taken design maturity as a basis for my methodological discussion for a reason. If the methodological discussion is not only about, but based on, knowledge and methods, DS as a research strategy will disintegrate - leading to the forming of methodological niches (Peffers et al., 2018). Given the heterogeneity of the field, this translates to research domain-specific niches, limiting the span of domain knowledge of would be academic designers. Thus, I argue, that in order for DS to make a decisive change in the practical relevance in 
the field of OM, it should base its methodological discussion around how theory is translated to practice - around how what ought to be becomes what is. 


\section{References}

Abaunza, F., Hameri, A.-P., \& Niemi, T. (2018). EEUI: a new measure to monitor and manage energy efficiency in data centers. International Journal of Productivity and Performance Management, 67(1), 111-127.

Adler, N. J., \& Harzing, A. (2009). When knowledge wins: Transcending the sense and nonsense of academic rankings. Academy of Management Learning \& Education, 8(1), 72-95.

Ahlemann, F., El Arbi, F., Kaiser, M. G., \& Heck, A. (2013). A process framework for theoretically grounded prescriptive research in the project management field. International Journal of Project Management, 31(1), $43-56$.

Akkermans, H., \& Voss, C. (2013). The service bullwhip effect. International Journal of Operations \& Production Management, 33(6), 765-788.

Ala-Risku, T. (2009). Installed base information: ensuring customer value and profitability after the Sale. Väitöskirja Teknillinen korkeakoulu. Helsinki University of Technology.

Ala-Risku, T., Kärkkäinen, M., \& Holmström, J. (2003). Evaluating the Applicability of Merge-in-transit. The International Journal of Logistics Management, 14(2), 67-82.

Alexander, C. (1999). The Origins of Pattern Theory: The Future of the Theory, and the Generation of a Living World. IEEE Software, 16(5), 71-82.

Alexander, C., Ishikawa, S., Silverstein, M., Jacobson, M., Fiksdahl-King, I., \& Angel, S. (1977). A pattern language: Towns, Buildings, Construction. Oxford: Oxford University Press.

Bacharach, S. B. (1989). Organizational theories: Some criteria for evaluation. Academy of Management Review, 14(4), 496-515.

Baines, T., \& Lightfoot, H. W. (2013). Servitization of the manufacturing firm: Exploring the operations practices and technologies that deliver advanced services. International Journal of Operations \& Production Management, 34(1), 2-35.

Barratt, M., Choi, T., \& Li, M. (2011). Qualitative case studies in operations management: Trends, research outcomes, and future research implications. Journal of Operations Management, 29(4), 329-342.

Bartunek, J. M., \& Rynes, S. L. (2010). The construction and contributions of "implications for practice": What's in them and what might they offer? Academy of Management Learning and Education, 9(1), 100-117.

Bendoly, E. (2006). Incorporating behavioral theory in OM empirical models. Journal of Operations Management, 24(6), 735-736.

Bendoly, E., Croson, R., Goncalves, P., \& Schultz, K. (2009). Bodies of Knowledge for Research in Behavioral Operations. Production and Operations Management, 19(4), 434-452.

Bendoly, E., Donohue, K., \& Schultz, K. (2006). Behavior in operations management: Assessing recent findings and revisiting old assumptions. 
Journal of Operations Management, 24, 737-752.

Beyer, J. M., \& Trice, H. M. (1982). The utilization process : A conceptual framework and synthesis of empirical findings. Administrative Science Quarterly, 27(4), 591-622.

Biernacki, P., \& Waldorf, D. (1981). Snowball sampling - Problems and techniques of chain referral sampling. Sociological Methods \& Research, $10(2), 141-163$.

Boeret, N. J. (1977). Air Canada saves with aircraft maintenance scheduling. Interfaces, 7(3), 1-13.

Bowen, D., \& Youngdahl, W. (1998). "Lean" service: in defense of a production-line approach. International Journal of Service Industry Management, 9(3), 207-225.

Brax, S. A., \& Jonsson, K. (2009). Developing integrated solution offerings for remote diagnostics: A comparative case study of two manufacturers.

International Journal of Operations \& Production Management, 29(5), 539-560.

Bromiley, P., \& Rau, D. (2016). Operations management and the resource based view: Another view. Journal of Operations Management, 41, 95106.

Bryman, A., \& Bell, E. (2011). Business Research Methods (3rd ed.). Oxford: Oxford University Press.

Bunge, M. (1967). Scientific Research II: The Search for Truth. Berlin: Springer-Verlag.

Busse, C., Schleper, M. C., Weilenmann, J., \& Wagner, S. M. (2017). Extending the supply chain visibility boundary: Utilizing stakeholders for identifying supply chain sustainability risks. International Journal of Physical Distribution \& Logistics Management, 47(1), 18-40.

Colen, P. J., \& Lambrecht, M. R. (2013). Product service systems: exploring operational practices. The Service Industries Journal, 33(5), 501-515.

Cooren, F., Thompson, F., Canestraro, D., \& Bodor, T. (2006). From agency to structure: Analysis of an episode in a facilitation process. Human Relations, 59(4), 533-565.

David, P. A. (1985). Clio and the economics of QWERTY. The American Economic Review, 75(2), 332-337.

de Treville, S., Edelson, N. M., Kharkar, A. N., \& Avanzi, B. (2009). Constructing useful theory: The case of Six Sigma. Operations Management Research, 1(1), 15-23.

Denyer, D., \& Tranfield, D. (2006). Using qualitative research synthesis to build an actionable knowledge base. Management Decision, 44(2), 213227.

Denyer, D., Tranfield, D., \& van Aken, J. E. (2008). Developing design propositions through research synthesis. Organization Studies, 29(3), 393-413.

Done, A., Voss, C., \& Rytter, N. G. (2011). Best practice interventions: Shortterm impact and long-term outcomes. Journal of Operations Management, 29(5), 500-513.

Dong, J., Zhao, Y., \& Peng, T. (2009). A review of Design Pattern mining techniques. International Journal of Software Engineering and Knowledge Engineering, 19(06), 823-855. 
Dubois, A., \& Gadde, L. E. (2002a). Systematic combining: An abductive approach to case research. Journal of Business Research, 55(7), 553-560.

Dubois, A., \& Gadde, L. E. (2002b). The construction industry as a loosely coupled system: Implications for productivity and innovation. Construction Management and Economics, 20(7), 621-631.

Duclos, L., Sih, S., \& Lummus, R. (1995). JIT in services: a review of current practices and future directions for research. International Journal of Service Industry Management, 6(5), 36-52.

Easton, G. (2010). Critical realism in case study research. Industrial Marketing Management, 39(1), 118-128.

Ebner, K., Mueller, B., Urbach, N., Riempp, G., \& Krcmar, H. (2016). Assessing IT Management's Performance: A Design Theory for Strategic IT Benchmarking. IEEE Transactions on Engineering Management, 63(1), 113-126.

Eisenhardt, K. M. (1989). Building theories from case study research. Academy of Management Review, 14(4), 532-550.

Eisenhardt, K. M., \& Graebner, M. E. (2007). Theory building from cases: Opportunities and challenges. Academy of Management Journal, 5O(1), 25-32.

Elfving, J. A., Ballard, G., \& Talvitie, U. (2010). Standardizing Logistics at the Corporate Level Towards Lean Logistics in Construction. In IGLC-18 (pp. 222-231). Haifa, Israel.

Erkoyuncu, J. A., Durugbo, C., \& Roy, R. (2013). Identifying uncertainties for industrial service delivery: a systems approach. International Journal of Production Research, 51(21), 6295-6315.

Finne, M. (2018). Improving university teaching: a professional service operation perspective. International Journal of Operations \& Production Management, 38(9), 1765-1795.

Forrester, J. W. (1992). Policies, decisions and information sources for modeling. European Journal of Operational Research, 59(1), 42-63.

Galbraith, J. R. (1974). Organization design: An information processing view. Interfaces, 4(3), 28-36.

Gino, F., \& Pisano, G. (2008). Toward a Theory of Behavioral Operations. Manufacturing \& Service Operations Management, 1O(4), 676-691.

Gioia, D. A., Corley, K. G., \& Hamilton, A. L. (2013). Seeking qualitative rigor in inductive research: Notes on the Gioia methodology. Organizational Research Methods, 16(1), 15-31.

Glaser, B. G., \& Strauss, A. L. (1999). The Discovery of Grounded Theory: Strategies for Qualitative Research. New York: Aldine Transaction.

Glaser, R. E. (1980). Bathtub and related failure rate characterizations. Journal of the American Statistical Association, 75(371), 667-672.

Grandori, A., \& Furnari, S. (2008). A Chemistry of Organization: Combinatory Analysis and Design. Organization Studies, 29(3), 459-485.

Grant, R. M. (1996a). Prospering in dynamically-competitive environments: Organizational capability as knowledge integration. Organization Science, 7(4), 375-387.

Grant, R. M. (1996b). Toward a knowledge-based theory of the firm. Strategic Management Journal, 17(Winter Special Issue), 109-122. 
Gregor, S., \& Hevner, A. R. (2013). Positioning and presenting Design Science Research for maximum impact. MIS Quarterly, 37(2), 337-355.

Gregor, S., \& Jones, D. (2007). The anatomy of a design theory. Journal of the Association of Information Systems, 8(5), 312-335.

Groop, J., Ketokivi, M., Gupta, M., \& Holmström, J. (2017). Improving home care: Knowledge creation through engagement and design. Journal of Operations Management, 53-56, 9-22.

Hadaya, P., \& Pellerin, R. (2010). Determinants of construction companies' use of web-based interorganizational information systems. Supply Chain Management: An International Journal, 15(5), 371-384.

Hambrick, D. C. (1994). What if the academy actually mattered? The Academy of Management Review, 19(1), 11-16.

Hammer, M. (2004). Deep change. Harvard Business Review, 82(4), 84-93.

Harrison, J., Carroll, G., \& Carley, K. (2007). Simulation modeling in organizational and management research. Academy of Management Review, 32(4), 1229-1245.

Hevner, A. R., March, S. T., Park, J., \& Ram, S. (2004). Design science in information systems research. MIS Quarterly, 28(1), 75-105.

Hinkka, V., Häkkinen, M., Holmström, J., \& Främling, K. (2015). Supply chain typology for configuring cost-efficient tracking in fashion logistics. The International Journal of Logistics Management, 26(1), 42-60.

Hofmann, E., \& Rutschmann, E. (2018). Big data analytics and demand forecasting in supply chains: a conceptual analysis. The International Journal of Logistics Management, 29(2), 739-766.

Holmström, J., Främling, K., \& Ala-Risku, T. (2010). The uses of tracking in operations management: Synthesis of a research program. International Journal of Production Economics, 126(2), 267-275.

Holmström, J., Ketokivi, M., \& Hameri, A.-P. (2009). Bridging practice and theory: a design science approach. Decision Sciences, 4O(1), 65-87.

Holweg, M. (2007). The genealogy of lean production. Journal of Operations Management, 25(2), 420-437.

Jääskeläinen, A., \& Roitto, J.-M. (2015). Designing a model for profiling organizational performance management. International Journal of Productivity and Performance Management, 64(1), 5-27.

Jain, S., Shao, G., \& Shin, S. J. (2017). Manufacturing data analytics using a virtual factory representation. International Journal of Production Research, 55(18), 5450-5464.

Jelinek, M., Romme, A. G. L., \& Boland, R. J. (2008). Introduction to the Special Issue - Organization Studies as a Science for Design: Creating Collaborative Artifacts and Research. Organization Studies, 29(3), 317329.

Jonsson, P., \& Holmström, J. (2016). Future of supply chain planning: closing the gaps between practice and promise. International Journal of Physical Distribution \& Logistics Management, 46(1), 62-81.

Kaipia, R., Holmström, J., Småros, J., \& Rajala, R. (2017). Information sharing for sales and operations planning: Contextualized solutions and mechanisms. Journal of Operations Management, 52, 15-29.

Kaipia, R., Holmström, J., \& Tanskanen, K. (2002). VMI : What are you losing if you let your customer place orders? Production Planning \& Control, 
13(1), 17-25.

Kärkkäinen, M., \& Holmström, J. (2002). Wireless product identification: enabler for handling efficiency, customisation and information sharing. Supply Chain Management: An International Journal, 7(4), 242-252.

Kauremaa, J., \& Tanskanen, K. (2016). Designing interorganizational information systems for supply chain integration: a framework. The International Journal of Logistics Management, 27(1), 71-94.

Ketokivi, M. (2009). Guest editorial: In what ways can academic research be relevant? Operations Management Research, 1(2), 81-85.

Ketokivi, M., \& Choi, T. (2014). Renaissance of case research as a scientific method. Journal of Operations Management, 32(5), 232-240.

Ketokivi, M., Mantere, S., \& Cornelissen, J. (2017). Reasoning by analogy and the progress of theory. Academy of Management Review, 42(4), 637658.

Kieser, A., Nicolai, A., \& Seidl, D. (2015). The Practical Relevance of Management Research: Turning the Debate on Relevance into a Rigorous Scientific Research Program. Academy of Management Annals, 9(1), 143-233.

Kjellsdotter Ivert, L., \& Jonsson, P. (2014). When should advanced planning and scheduling systems be used in sales and operations planning? International Journal of Operations \& Production Management, 34(10), 1338-1362.

Klutke, G., Kiessler, P. C., \& Wortman, M. A. (2003). A critical look at the bathtub curve. IEEE Transactions on Reliability, 52(1), 125-129.

Koskela, L. (2017). Why is management research irrelevant? Construction Management and Economics, 35(1-2), 4-23.

Kowalkowski, C. (2008). Service productivity gains through information and communication technology applications: a service marketing approach. International Journal of Knowledge Management Studies, 2(1), 96-114.

Kowalkowski, C., \& Brehmer, P.-O. (2008). Technology as a driver for changing customer-provider interfaces: Evidence from industrial service production. Management Research News, 31(10), 746-757.

Law, A. M. (2003). How to conduct a successful simulation study. In S. Chick, P. J. Sánches, D. Ferrin, \& D. J. Morrice (Eds.), Proceedings of the 2003 Winter Simulation Conference (pp. 66-70).

Leonard-Barton, D. (1990). A dual methodology for case studies: Synergistic use of a longitudinal single site with replicated multiple sites. Organization Science, 1(3), 248-266.

Maier, A. M., Moultrie, J., \& Clarkson, P. J. (2012). Assessing Organizational Capabilities: Reviewing and Guiding the Development of Maturity Grids. IEEE Transactions on Engineering Management, 59(1), 138-159.

Maniak, R., \& Midler, C. (2014). Multiproject lineage management: Bridging project management and design-based innovation strategy. International Journal of Project Management, 32(7), 1146-1156.

Mantere, S., \& Ketokivi, M. (2013). Reasoning in organization science. Academy of Management Review, 38(1), 70-89.

March, S. T., \& Smith, G. F. (1995). Design and natural science research on information technology. Decision Support Systems, 15(4), 251-266.

Martela, F. (2015). Fallible Inquiry with Ethical Ends-in-View: A Pragmatist 
Philosophy of Science for Organizational Research. Organization Studies, (forthcoming), 1-27.

McCutcheon, D. M., \& Meredith, J. R. (1993). Conducting case study research in operations management. Journal of Operations Management, 11(3), $239-256$.

Meyer, G. G., Buijs, P., Szirbik, J. C., \& Wortmann, (Hans). (2014). Intelligent products for enhancing the utilization of tracking technology in transportation. International Journal of Operations \& Production Management, 34(4), 422-446.

Miles, M. B., \& Huberman, A. M. (1994). Qualitative Data Analysis: An Expanded Sourcebook (2nd ed.). Thousand Oaks, CA: Sage Publications Inc.

Moeller, S. (2010). Characteristics of services - a new approach uncovers their value. Journal of Services Marketing, 24(5), 359-368.

Moon, K.-L., \& Ngai, E. W. T. (2010). R\&D framework for an intelligent fabric sample management system: A design science approach. International Journal of Operations \& Production Management, 30(7), 721-743.

Noy, C. (2008). Sampling knowledge: The hermeneutics of snowball sampling in qualitative research. International Journal of Social Research Methodology, 11(4), 327-344.

Öhman, M., Finne, M., \& Holmström, J. (2015). Measuring service outcomes for adaptive preventive maintenance. International Journal of Production Economics, 170, 457-467.

Öhman, M., Laine, M., \& Holmström, J. (2016). Aircraft fleet maintenance scheduling: heuristics for workload balancing. In R. W. Grubbström \& H. H. Hinterhuber (Eds.), 19th International Working Seminar on Production Economics, Volume 3 (pp. 399-410).

Ohno, T. (1988). Toyota Production System: Beyond large-scale production. New York, NY: Productivity Press.

Oliva, R., \& Kallenberg, R. (2003). Managing the transition from products to services. International Journal of Service Industry Management, 14(2), 160-172.

Oliva, R., \& Sterman, J. D. (2001). Cutting corners and working overtime: Quality erosion in the service industry. Management Science, 47(7), 894914.

Orlikowski, W. J. (2000). Using Technology and Constituting Structures: A Practice Lens for Studying Technology in Organizations. Organization Science, 11(4), 404-428.

Orlikowski, W. J., \& Gash, D. C. (1994). Technological frames: making sense of information technology in organizations. ACM Transactions on Information Systems, 12(2), 174-207.

Österle, H., Becker, J., Frank, U., Hess, T., Karagiannis, D., Krcmar, H., ... Sinz, E. J. (2011). Memorandum on design-oriented information systems research. European Journal of Information Systems, 2O(1), 7-10.

Pandza, K., \& Thorpe, R. (2010). Management as design, but what kind of design? An appraisal of the design science analogy for management. British Journal of Management, 21(1), 171-186.

Pawson, R., \& Tilley, N. (1997). Realistic Evaluation. London: Sage Publications. 
Peffers, K., Tuunanen, T., \& Niehaves, B. (2018). Design science research genres: introduction to the special issue on exemplars and criteria for applicable design science research. European Journal of Information Systems, 27(2), 129-139.

Peffers, K., Tuunanen, T., Rothenberger, M. A., \& Chatterjee, S. (2007). A Design Science research methodology for information systems research. Journal of Management Information Systems, 24(3), 45-77.

Pfeffer, J., \& Sutton, R. I. (2006). Evidence-based management. Harvard Business Review, 84(1), 62-74.

Popper, K. (1980). The Logic of Scientific Discovery. London: Unwin Hyman.

Porter, M. E., \& Heppelmann, J. E. (2014). How smart, connected products are transforming competition. Harward Business Review, (November), 123.

Pournader, M., Tabassi, A. A., \& Baloh, P. (2015). A three-step design science approach to develop a novel human resource-planning framework in projects: The cases of construction projects in USA, Europe, and Iran. International Journal of Project Management, 33(2), 419-434.

Rämänen, J., Mahlamäki, K., Borgman, J., \& Nieminen, M. (2013). Human Role in Industrial Installed Base Information Gathering. In 2nd International Through-life Engineering Services Conference (Vol. 11, pp. 406-411). Elsevier B.V.

Reinerth, D., Busse, C., \& Wagner, S. M. (2018). Using Country Sustainability Risk to Inform Sustainable Supply Chain Management: A Design Science Study. Journal of Business Logistics, 1-24.

Romme, A. G. L. (2003). Making a Difference: Organization as Design. Organization Science, 14(5), 558-573.

Romme, A. G. L., Avenier, M. J., Denyer, D., Hodgkinson, G. P., Pandza, K., Starkey, K., \& Worren, N. (2015). Towards Common Ground and Trading Zones in Management Research and Practice. British Journal of Management, 26(3), 544-559.

Sampson, S. E., \& Froehle, C. M. (2006). Foundations and implications of a proposed unified services theory. Production and Operations Management, 15(2), 329-343.

Sarasvathy, S. D. (2001). Causation and effectuation: Toward a theoretical shift from economic inevitability to entrepreneurial contingency. Academy of Management Review, 26(2), 243-263.

Sarasvathy, S. D. (2003). Entrepreneurship as a science of the artificial. Journal of Economic Psychology, 24(2), 203-220.

Schmenner, R. W., \& Swink, M. L. (1998). On theory in operations management. Journal of Operations Management, 17(1), 97-113.

Schmenner, R. W., Wassenhove, L. Van, Ketokivi, M., Heyl, J., \& Lusch, R. F. (2009). Too much theory, not enough understanding. Journal of Operations Management, 27(5), 339-343.

Schonberger, R. J. (2008). World Class Manufacturing. New York, NY: The Free Press.

Scudder, G. D., \& Hill, C. A. (1998). A review and classification of empirical research in operations management. Journal of Operations Management, 16(1), 91-101.

Seddon, J., Donovan, B. O., \& Zokaei, K. (2011). Rethinking Lean Service. In 
M. Macintyre, G. Parry, \& J. Angelis (Eds.), Service Design and Delivery, Service Science: Research and Innovations in the Service Economy (pp. 41-60). Boston, MA: Springer US.

Sein, M. K., Henfridsson, O., Purao, S., Rossi, M., \& Lindgren, R. (2011). Action design research. MIS Quarterly, 35(1), 37.

Siggelkow, N. (2007). Persuasion With Case Studies. Academy of Management Journal, 5o(1), 20-24.

Simon, H. A. (1962). The architecture of complexity. Proceedings of the American Philosophical Society, 106(6), 467-482.

Simon, H. A. (1996). The Sciences of the Artificial (3rd ed.). Cambridge (MA): MIT Press.

Simon, H. A. (2000). Administrative behavior (4th ed.). New York: The Free Press.

Smithson, J. (2000). Using and analysing focus groups: Limitations and possibilities. International Journal of Social Research Methodology, 3(2), 103-119.

Soinio, J., Tanskanen, K., \& Finne, M. (2012). How logistics-service providers can develop value-added services for SMEs: a dyadic perspective. The International Journal of Logistics Management, 23(1), 31-49.

Sousa, R., \& Voss, C. A. (2008). Contingency research in operations management practices. Journal of Operations Management, 26(6), 697713 .

Stuart, I., McCutcheon, D., Handfield, R., McLachlin, R., \& Samson, D. (2002). Effective case research in operations management: A process perspective. Journal of Operations Management, 2O(5), 419-433.

Tanskanen, K., Holmström, J., Elfving, J., \& Talvitie, U. (2009). Vendormanaged-inventory (VMI) in construction. International Journal of Productivity and Performance Management, 58(1), 29-40.

Tanskanen, K., Holmström, J., \& Öhman, M. (2015). Generative mechanisms of the adoption of logistics innovation: The case of On-site Shops in construction supply chains. Journal of Business Logistics, 36(2), 139159.

Towill, D. R., Zhou, L., \& Disney, S. M. (2007). Reducing the bullwhip effect: Looking through the appropriate lens. International Journal of Production Economics, 108(1-2), 444-453.

Tushman, M. L., \& Nadler, D. A. (1978). Information processing as an integrating concept in organizatonal design. Academy of Management Review, 3(3), 613-624.

Ulaga, W., \& Reinartz, W. J. (2011). Hybrid offerings: How manufacturing firms combine goods and services successfully. Journal of Marketing, 75(November), 5-23.

van Aken, J. E. (2004). Management research based on the paradigm of the Design Sciences: The quest for field-tested and grounded technological rules. Journal of Management Studies, 41(2), 219-246.

van Aken, J. E. (2005). Management Research as a Design Science: Articulating the Research Products of Mode 2 Knowledge Production in Management. British Journal of Management, 16(1), 19-36.

van Aken, J. E., Chandrasekaran, A., \& Halman, J. (2016). Conducting and publishing design science research: Inaugural essay of the design science 
department of the Journal of Operations Management. Journal of Operations Management, 47-48, 1-8.

Voss, C., Tsikriktsis, N., \& Frohlich, M. (2002). Case research in operations management. International Journal of Operations \& Production Management, 22(2), 195-219.

Walls, J. G., Widemeyer, G. R., \& El Sawy, O. A. (1992). Building an Information System Design theory for Vigilant EIS. Information Systems Research, 3(1), 36-59.

Wee, D., Kelly, R., Cattel, J., \& Breunig, M. (2015). Industry 4.o - how to navigate digitization of the manufacturing sector. McKinsey \& Company, $1-62$.

Wicks, A. C., \& Freeman, R. E. (1998). Organization Studies and the New Pragmatism: Positivism, Anti-positivism, and the Search for Ethics. Organization Science, 9(2), 123-140.

Womack, J. P., Jones, D. T., \& Roos, D. (1990). The Machine that Changed the World. New York: Macmillan Publishing Company.

Wu, Z., \& Choi, T. Y. (2005). Supplier-supplier relationships in the buyersupplier triad: Building theories from eight case studies. Journal of Operations Management, 24(1), 27-52.

Wu, Z., Choi, T. Y., \& Rungtusanatham, M. J. (2010). Supplier-supplier relationships in buyer-supplier-supplier triads: Implications for supplier performance. Journal of Operations Management, 28(2), 115-123.

Yin, R. K. (2009). Case study research: Design and methods (4th ed.). Thousand Oaks, CA: Sage Publications Ltd. 


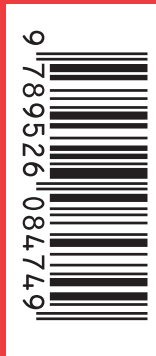

ISBN 978-952-60-8474-9 (printed)

ISBN 978-952-60-8487-9 (pdf)

ISSN $1799-4934$ (printed)

ISSN 1799-4942 (pdf)

Aalto University

School of Science

Department of Industrial Engineering and Management

www.aalto.f $\mathrm{i}$

ART +

DESIGN +

ARCHITECTURE

SCIENCE +

TECHNOLOGY

CROSSOVER

DOCTORAL

DISSERTATIONS 